\title{
MINIMUM MASS OF MODERATOR REQUIRED FOR CRITICALITY OF HOMOGENEOUS LOW-ENRICHED URANIUM SYSTEMS
}

\author{
W. C. Jordan \\ J. C. Turner \\ Computing and Telecommunications Division \\ at Oak Ridge National Laboratory \\ Oak Ridge, Tennessee 37831
}

Date Published: December 1992

MARTIN MARIETTA ENERGY SYSTEMS, INC. managing the

Oak Ridge National Laboratory Oak Ridge Y-12 Plant

Oak Ridge K-25 Site Paducah Gasenus Diffusion Plant for the

U.S. DEPARTMENT OF ENERGY under contract DE-AC05-84OR21400 


\section{CONTENTS}

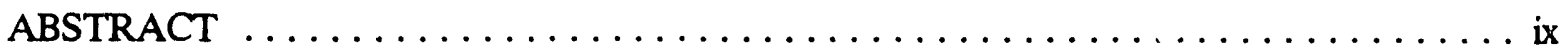

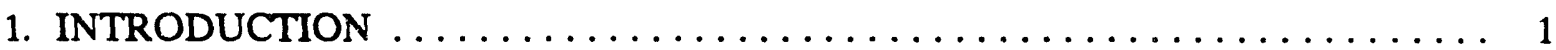

2. MINIMUM MASS OF MODERATOR REQUIRED FOR CRITICALITY

OF HOMOGENEOUS LOW-ENRICHED URANIUM SYSTEMS $\ldots \ldots \ldots \ldots 3$

2.1 CALCULATIONAL RESULTS $\ldots \ldots \ldots \ldots \ldots \ldots \ldots \ldots \ldots \ldots \ldots$

2.2 PROCEDURES FOR EXTENDING THE CALCULATED RESULTS . . . 11

3. INVESTIGATION OF A CALCULATIONAL DISCREPANCY $\ldots \ldots \ldots \ldots \ldots 14$

3.1 COMPARISON WITH OTHER CROSS-SECTION LIBRAPIES $\ldots \ldots \ldots 14$

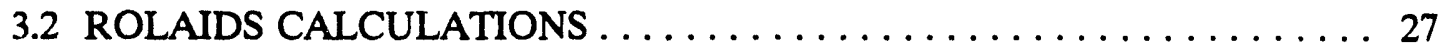

3.3 THE PCTR ANALYSIS $\ldots \ldots \ldots \ldots \ldots \ldots \ldots \ldots \ldots \ldots \ldots \ldots$

4. EFFECTS OF MODERATION LEVEL ON THE NEUTRON SPECTRUM . . . . 32

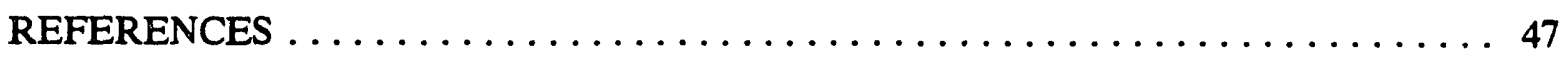

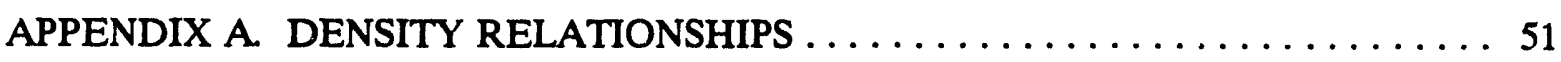

APPENDIX B. TABLES OF CALCULATED VALUES FOR SECTION $2 \ldots \ldots \ldots$

APPENDIX C. RESULTS OF THE 1983 MINIMUM MODERATOR MASS STUDY 63

APPENDIX D. TABLES OF CALCULATED VALUES FOR SECTION $3.1 \ldots \ldots$ 


\section{LIST OF FIGURES}

Figure

Page

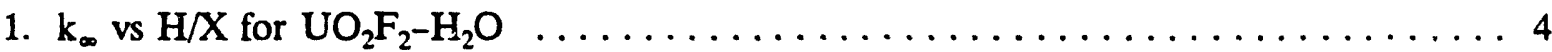

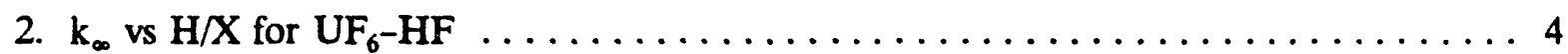

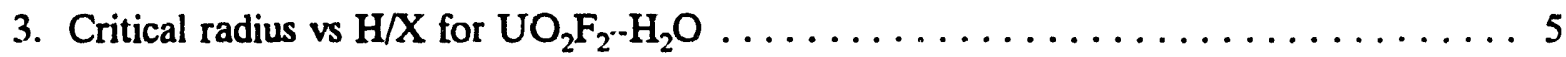

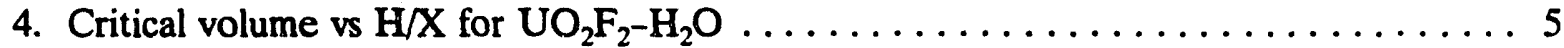

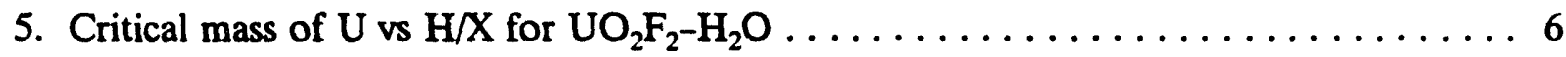

6. Mass of water required for criticality vs $\mathrm{H} / \mathrm{X}$ for $\mathrm{UO}_{2} \mathrm{~F}_{2}-\mathrm{H}_{2} \mathrm{O} \ldots \ldots \ldots \ldots \ldots \ldots \ldots$

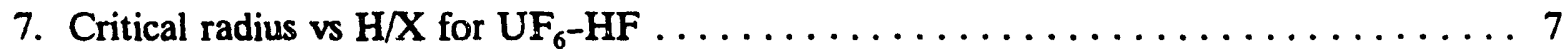

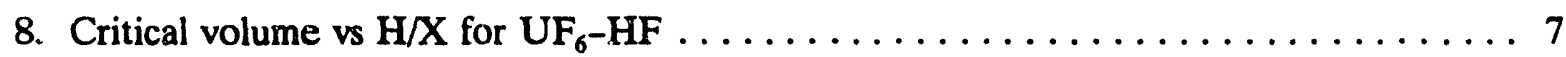

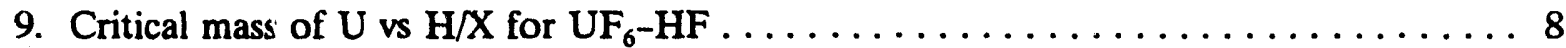

10. Mass of $\mathrm{HF}$ for criticality vs $\mathrm{H} / \mathrm{X}$ for $\mathrm{UF}_{6}-\mathrm{HF} \ldots \ldots \ldots \ldots \ldots \ldots \ldots \ldots$

11. Estimated minimum conditions for criticality $\mathrm{UO}_{2} \mathrm{~F}_{2}-\mathrm{H}_{2} \mathrm{O} \ldots \ldots \ldots \ldots \ldots \ldots \ldots$

12. Estimated minimum conditions for criticality $\mathrm{UF}_{6}-\mathrm{HF} @ 20^{\circ} \mathrm{C} \ldots \ldots \ldots \ldots \ldots \ldots$

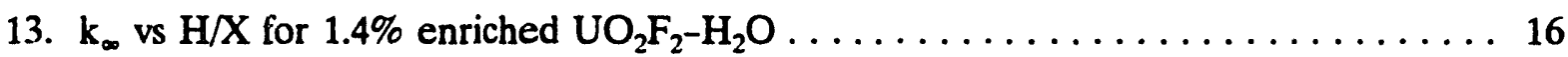

14. $\mathrm{k}_{\infty}$ vs $\mathrm{H} / \mathrm{X}$ for $1.7 \%$ enriched $\mathrm{UO}_{2} \mathrm{~F}_{2}-\mathrm{H}_{2} \mathrm{O} \ldots \ldots \ldots \ldots \ldots \ldots \ldots \ldots \ldots$

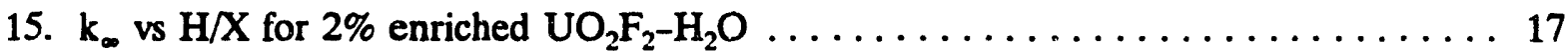

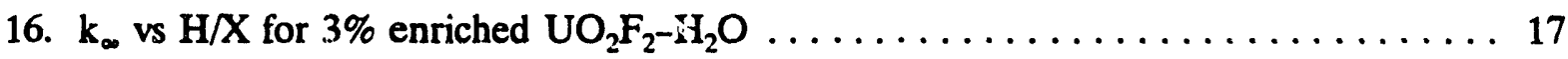

17. $\mathrm{k}_{\infty}$ vs $\mathrm{H} / \mathrm{X}$ for $5 \%$ enriched $\mathrm{UO}_{2} \mathrm{~F}_{2}-\mathrm{H}_{2} \mathrm{O} \ldots \ldots \ldots \ldots \ldots \ldots \ldots \ldots \ldots \ldots$

18. $\mathrm{k}_{\infty}$ vs $\mathrm{H} / \mathrm{X}$ for $1.4 \%$ enriched $\mathrm{UF}_{6}-\mathrm{HF} \ldots \ldots \ldots \ldots \ldots \ldots \ldots \ldots \ldots \ldots$

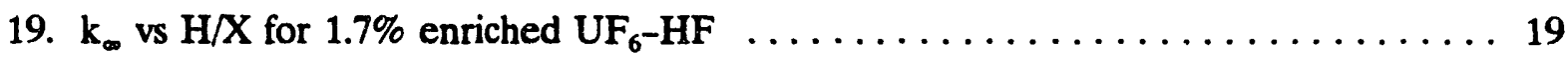

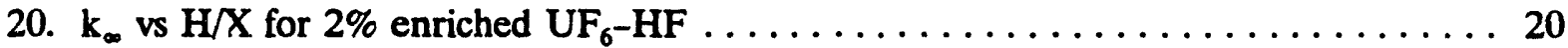

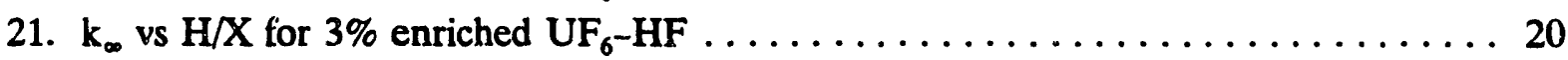

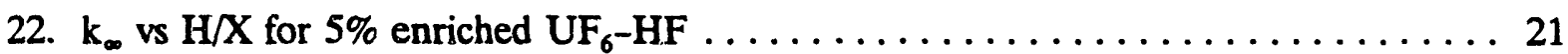

23. Knight-modified Hansen-Roach to SCALE 27-group library comparison,

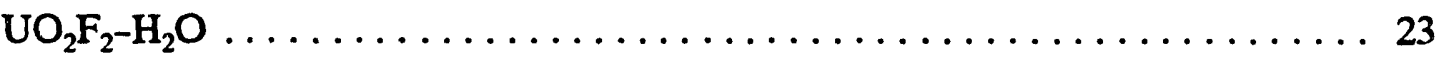

24. Knight-modified Hansen-Roach to SCALE 27-group library comparison,

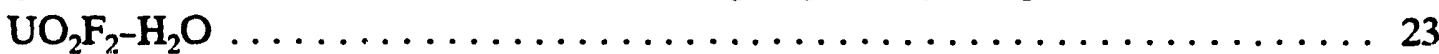

25. Knight-modified Hansen-Roach to SCALE 27-group library comparison,

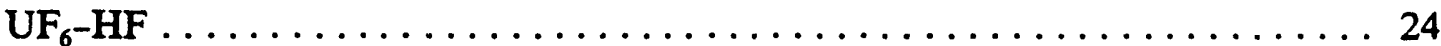

26. Knight-modified $\mathrm{F}$.ansen-Roach to SCALE 27-group library comparison,

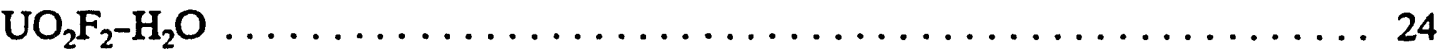

27. SCALE 16-group to SCALE 27-group library comparison, $\mathrm{UO}_{2} \mathrm{~F}_{2}-\mathrm{H}_{2} \mathrm{O} \ldots \ldots \ldots 25$

28. SCALE 16-group to SCALE 27-group library comparison, $\mathrm{UO}_{2} \mathrm{~F}_{2}-\mathrm{H}_{2} \mathrm{O} \ldots \ldots \ldots 25$

29. LAW 238-group to SCALE 27-group library comparison, $\mathrm{UO}_{2} \mathrm{~F}_{2}-\mathrm{H}_{2} \mathrm{O} \ldots \ldots \ldots \ldots$

30. LAW 238-group to SCALE 27-group library comparison, $\mathrm{UO}_{2} \mathrm{~F}_{2}-\mathrm{H}_{2} \mathrm{O} \ldots \ldots \ldots 26$

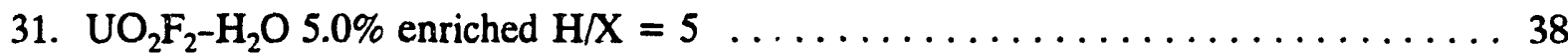




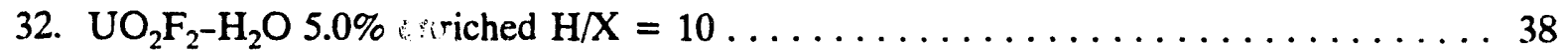

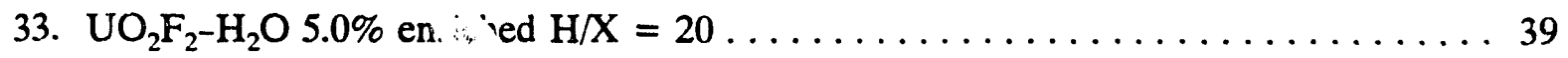

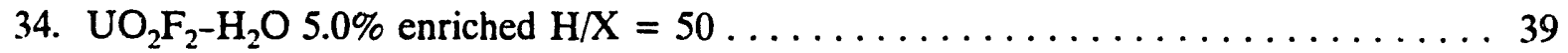

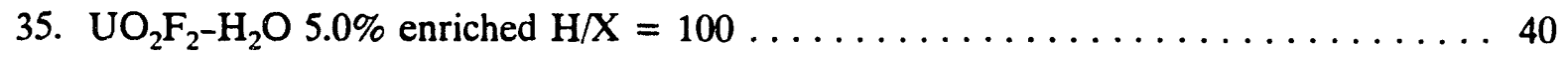

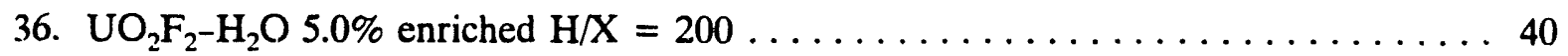

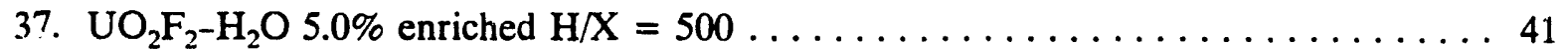

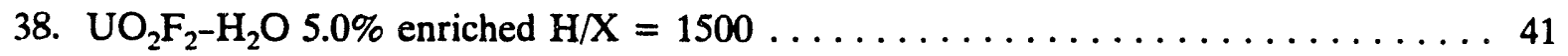

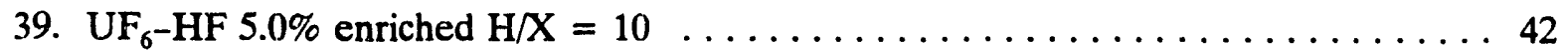

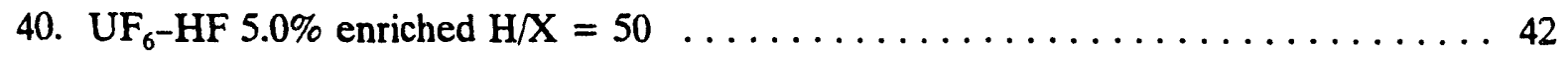

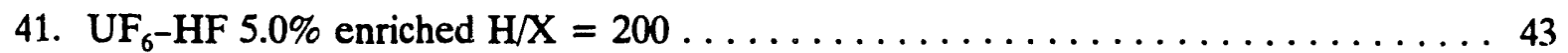

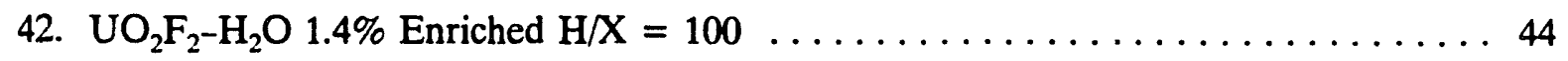

43. $\mathrm{UO}_{2} \mathrm{~F}_{2}-\mathrm{H}_{2} \mathrm{O} 1.4 \%$ Enriched $\mathrm{H} / \mathrm{X}=500 \ldots \ldots \ldots \ldots \ldots \ldots \ldots \ldots \ldots \ldots$

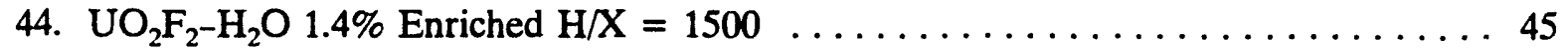




\section{LIST OF TABLES}

Table

Page

1. Estimated minimum critical parameters for $\mathrm{UO}_{2} \mathrm{~F}_{2}-\mathrm{H}_{2} \mathrm{O} \ldots \ldots \ldots \ldots \ldots \ldots$

2. Estimated minimum critical parameters for $\mathrm{UF}_{6}-\mathrm{HF} \ldots \ldots \ldots \ldots \ldots \ldots$

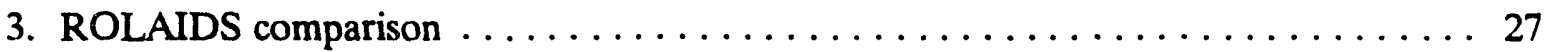

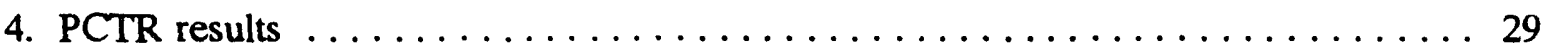

5. $\mathrm{H}-\mathrm{R}$ replacement calculations for $\mathrm{U}(5) \mathrm{O}_{2} \mathrm{~F}_{2}$ and water at $\mathrm{H} / \mathrm{X}=5 \ldots \ldots \ldots \ldots$

6. Intercomparison of XSDRNPM and KENO V.a results $\ldots \ldots \ldots \ldots \ldots \ldots \ldots$

7. Selected spectral information for $\mathrm{U}(5) \mathrm{O}_{2} \mathrm{~F}_{2}-\mathrm{H}_{2} \mathrm{O}$ systems $\ldots \ldots \ldots \ldots \ldots \ldots \ldots . \ldots \ldots$

8. Selected spectral information for $\mathrm{U}(1.4) \mathrm{O}_{2} \mathrm{~F}_{2}-\mathrm{H}_{2} \mathrm{O}$ systems $\ldots \ldots \ldots \ldots \ldots \ldots \ldots$

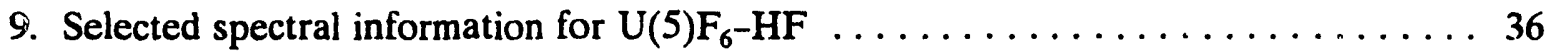

10. AEG for several calculated critical spheres $\ldots \ldots \ldots \ldots \ldots \ldots \ldots \ldots \ldots \ldots$

A.1. Properties of uranium and moderating compounds $\ldots \ldots \ldots \ldots \ldots \ldots \ldots \ldots$

A.2. Temperature variation of several compounds $\ldots \ldots \ldots \ldots \ldots \ldots \ldots \ldots \ldots$

A.3. Physical properties of $\mathrm{UO}_{2} \mathrm{~F}_{2}-\mathrm{H}_{2} \mathrm{O}$ mixtures $\ldots \ldots \ldots \ldots \ldots \ldots \ldots \ldots \ldots \ldots$

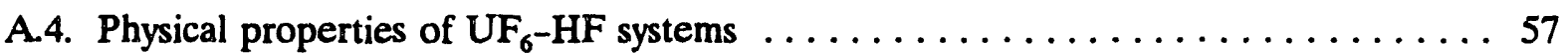

B.1. $\mathrm{k}_{\infty}$ for $\mathrm{UO}_{2} \mathrm{~F}_{2}-\mathrm{H}_{2} \mathrm{O}$ systems using the SCALE 27 -group library $\ldots \ldots \ldots \ldots \ldots$

B.2. $k_{\infty}$ for $\mathrm{UF}_{6}$-HF systems using the SCALE 27-group library $\ldots \ldots \ldots \ldots \ldots \ldots$

B.3. Critical parameters for $\mathrm{UO}_{2} \mathrm{~F}_{2}-\mathrm{H}_{2} \mathrm{O}$ using the SCALE 27-group library $\ldots \ldots \ldots 61$

B.4. Critical parameters for $\mathrm{UF}_{6}-\mathrm{HF}$ using the SCALE 27 -group library $\ldots \ldots \ldots \ldots 6$

C.1. $\mathrm{k}_{\infty}$ for $\mathrm{UO}_{2} \mathrm{~F}_{2}-\mathrm{H}_{2} \mathrm{O}$ systems using the Knight-modified Hansen-Roach cross sections 64

C.2. $k_{\infty} U_{6}-H F$ systems using the Knight-modified Hansen-Roach cross sections . . . . 64

C.3. Critical parameters for $\mathrm{UO}_{2} \mathrm{~F}_{2}-\mathrm{H}_{2} \mathrm{O}$ using the Knight-modified

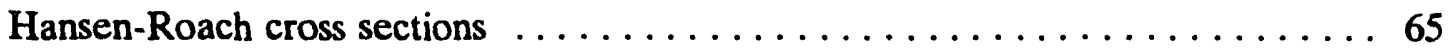

C.4. Critical parameters for $\mathrm{UF}_{6}$-HF systems using the Knight-modified

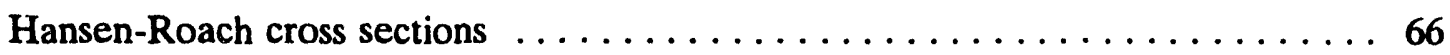

D.1. $\mathrm{k}_{\infty}$ for $\mathrm{UO}_{2} \mathrm{~F}_{2}-\mathrm{H}_{2} \mathrm{O}$ systems using the SCALE 16-group library $\ldots \ldots \ldots \ldots \ldots$

D.2. $\mathrm{k}_{\infty}$ for $\mathrm{UF}_{6}$-HF systems using the SCALE 16-group library $\ldots \ldots \ldots \ldots \ldots$

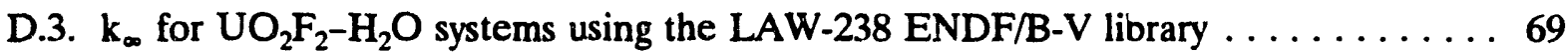

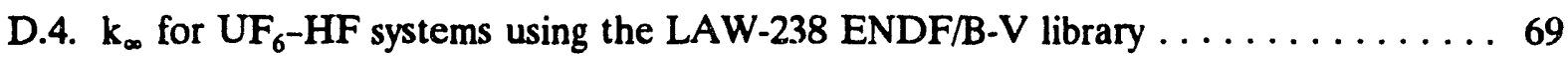




\section{ACKNOWLEDGMENTS}

The authors gratefully acknowledge the interest and support of the Uranium Enrichment Program for this work. 


\begin{abstract}
A parametric calculational analysis has been performed in order to estimate the minimum mass of moderator required for criticality of homogeneous low-enriched uranium systems. The analysis was performed using a version of the SCALE-4.0 code system and the 27-group ENDF/B-IV cross-section library. Water-moderated uranyl fluoride $\left(\mathrm{UO}_{2} \mathrm{~F}_{2}\right.$ and $\left.\mathrm{H}_{2} \mathrm{O}\right)$ and hydrofluoric-acid-moderated uranium hexaflouride $\left(\mathrm{UF}_{6}\right.$ and $\mathrm{HF}$ ) systems were considered in the analysis over enrichments of 1.4 to $5 \mathrm{wt} \%{ }^{235} \mathrm{U}$. Estimates of the minimum critical volume, minimum critical mass of uranium, and the minimum mass of moderator required for criticality are presented.

There was significant disagreement between the values generated in this study when compared with a similar undocumented study performed in 1983 using ANISN and the Knightmodified Hansen-Roach cross sections. An investigation into the cause of the disagreement was made, and the results are presented.
\end{abstract}




\section{INTRODUCTION}

Where practicable, the nuclear criticality safety of equipment or operations that involve fissile material should be based on single-parameter limits, such as safe mass or geometry, for a specified enrichment. ${ }^{1}$ These single-parameter limits are easily controlled and verifiable, and require a minimum of administrative control. The limits are well established and are usually based on optimum moderation and full reflection for the fissile material form under consideration.

There are, however, instances in which single-parameter limits are extremely conservative and unnecessarily limit the size of equipment or mais of uranium. In these cases, multiple parameter limits that control additional variables in conjunction with the mass or geometry may be safely imposed. A common second variable used in industry is the moderation level of the uranium in the process.

An example of a "moderation-limited" fissile material control is the subcritical mass limit for highly enriched uranium metal. ${ }^{1,2}$ The single-parameter mass limit for ${ }^{235} \mathrm{U}$ metal is $20.1 \mathrm{~kg}$. This limit is applicable only to a unit that has no reentrant space that can be occupied by water or another moderator. In the absence of any moderation control, the single-parameter subcritical mass limit is $760 \mathrm{~g}$.

Another example of moderation-limited fissile material control may be seen in the use

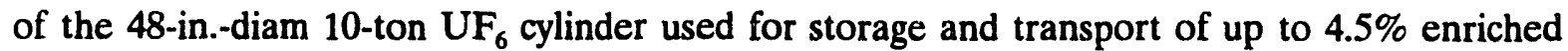
uranium. $^{3}$ The cylinder is safe due to moderation control. The cylinder wall isolates the fissile material from any moderators. The integrity of the wall can be checked through monitoring of the cylinder pressure (a vacuum condition). $\mathrm{UF}_{6}$ reacts with water to form $\mathrm{UO}_{2} \mathrm{~F}_{2}$ and $\mathrm{HF}$. The presence of $\mathrm{HF}$ in the cylinder is easily detected by measuring the pressure of the cylinder at a specified temperature. In the absence of moderation control, the subcritical mass limit for $4.5 \%$ enriched $\mathrm{UF}_{6}$ would be on the order of $43.5 \mathrm{~kg}$ of uranium; the subcritical infinite cylindrical geometry limit would be a diameter of about 11.0 in.

In each of these examples, the mass of the fissile material significantly exceeds the minimum critical values based on optimum moderation.

A characteristic of low-enriched uranium is that uranium enriched to less than about 5.6 wt $\%{ }^{235} \mathrm{U}$ cannot be made critical in the absence of a moderator. Thus, moderation control is of special interest in operations involving low-enriched uranium. It also suggests that a singieparameter limit based on the mass of moderator could be established for low-enriched uranium.

The single-parameter limit on moderator mass has similar characteristics to other singleparameter limits because, by controlling this parameter, a system is safely subcritical independent of the geometry, the manner in which the moderator is intermixed, and the reflective conditions of the material.

The purpose of this report is to establish estimates of the minimum moderator mass required for criticality for $\mathrm{H}_{2} \mathrm{O}$-moderated $\mathrm{UO}_{2} \mathrm{~F}_{2}$ and $\mathrm{HF}$-moderated $\mathrm{UF}_{6}$ systems involving enrichments ranging from 1.4 to $5 \mathrm{wt} \%{ }^{235} \mathrm{U}$. A similar undocumented study was performed at 
the Oak Ridge Gaseous Diffusion Plant (ORGDP) in Oak Ridge in 1983. The original intent of this analysis was to reconfirm the 1983 calculations using current codes and cross sections and to more formally document the results. The results of this stuidy did not agree well with the values determined in 1983 . The disagreement was significant enough to warrant investigation to determine the cause of the disagreement. Subsequently, the scope of this report was expanded into additional parts (Sects. 3 and 4).

In Sect. 2, the methodology for estimating the minimum mass of moderator is presented. Included are the techniques used to estimate the physical characteristics, such as uranium density, as a function of moderation level for the two mixtures considered. The results of infinite media multiplication calculations are given, along with the calculational results used to estimate the minimum mass of moderator required for criticality. Procedures for extending the results and estimating the critical spherical radius for systems of the same composition, but with different material densities, reflection conditions, or infinite media multiplication factors, are given.

In Sect. 3, the differences between the 1983 calculations and the current calculations performed with SCALE-4.0 (ref. 4) are investigated. In this investigation five cross-section sets were examined: (1) the SCALE 27-group ENDFB/IV library, ${ }^{5}$ (2) the LAW 238-group ENDF/B-V library, ${ }^{6}$ and (3) three variations of the Hansen-Roach 16-group cross-section set the Knight-modified Hansen-Roach cross sections as distributed with KENO-IV, ${ }^{7,8}$ the SC:ALE 16-group library, and the original Hansen-Roach cross sections. ${ }^{9}$

The minimum critical radius, volume, and mass predicted using SCALE-4.0 and the 27group ENDF/B-IV library are greater than those estimated in 1983 using ANISN $^{10}$ and the Knight-modified Hansen-Roach cross sections. There are also large differences in the calculated infinite media multiplication factors. An investigation was conducted to determine the possible causes of these differences. The investigation consists primarily of a comparison of cross-section performance on infinite media calculations. A comparison between the SCALE-4.0 results and the 1983 results are presented. The infinite media calculations presented in Sect. 2 are repeated using the SCALE 16-group library. These calculations were also performed again using the LAW 238-group ENDF/B-V library as an independent reference. Results of calculations using ENDF/B-IV, ENDF/B-V, and Knight-modified Hansen-Roach cross sections are presented. The ROLAIDS ${ }^{11}$ code is used to determine the adequacy of the NITAV: $\mathrm{L}^{12}$ resonance region crosssection processing. The performance of each cross-section library on several low-enriched, lowmoderated systems that have experimentally measured infinite media multiplication factors, referred to here as the PCTR experiments, ${ }^{13-15}$ is presented. A final comparison is then made using the original Hansen-Roach 16-group cross sections.

In Sect. 4, a brief discussion is presented on the effects of moderation level and enrichment on the neutron spectrum. An attempt is made to determine the adequacy of various parameters in establishing the area and range of applicability of a validation. 


\section{MINIMUM MASS OF MODERATOR REQUIRED FOR CRITICALITY OF HOMOGENEOUS LOW-ENRICHED URANIUM SYSTEMS}

\subsection{CALCULATIONAL RESULTS}

As a first step in determining the minimum mass of moderator required for criticality, the physical characteristics of the fissile mixtures used in the analysis must be accurately described over the specified range of parameters. In this case, the uranium density as a function of the moderation level specified as an $\mathrm{H} / \mathrm{X}$ (hydrogen-to-fissile uranium atomic ratio) for $\mathrm{H}_{2} \mathrm{O}$ moderated $\mathrm{UO}_{2} \mathrm{~F}_{2}$ and $\mathrm{HF}$-moderated $\mathrm{UF}_{6}$. The density formulations given in Appendix $\mathrm{A}$ were used to estimate the densities at a temperature of $20^{\circ} \mathrm{C}$. The temperature used for the determination of the theoretical densities is important because both of these systems have components whose density is a function of temperature.

Uranium-235 enrichments of $5 \%, 4 \%, 3 \%, 2 \%, 1.7 \%$, and $1.4 \%$ were considered. The uranium densities were predicted using the equations given in Appendix $A$ and then used to obtain the compound and moderator densities for the corresponding $\mathrm{H} / \mathrm{U}$ (hydrogen-to-uranium atomic ratio) value (also tabulated in Appendix A). Tables A.3 and A.4 give the values of uranium, uranium compound, and moderator densities in the mixture as a function of $\mathrm{H} / \mathrm{X}$ for $\mathrm{UO}_{2} \mathrm{~F}_{2}-\mathrm{H}_{2} \mathrm{O}$ and $\mathrm{UF}_{6}-\mathrm{HF}$ systems, respectively.

Criticality Safety Analysis Sequence No. 1X (CSAS1X) of the CSAS4 module ${ }^{16}$ in SCALE-4.0 was used to perform infinite media multiplication $\left(k_{\infty}\right)$ calculations for each system described in Tabies A.3 and A.4. This control sequence prepares input data and executes BONAMI, ${ }^{17}$ NII. NL, and XSDRNPM ${ }^{18}$ The results of these calculations using the 27-group ENDF/B-IV cross-section library are given in Tables B.1 and B.2 and plotted in Figs. 1 and 2.

The infinite media calculations were used to determine the $\mathrm{H} / \mathrm{X}$ range where peak reactivity occurs for each enrichment. The minimum volume system will occur in the $\mathrm{H} / \mathrm{X}$ region of peak reactivity. The minimum-mass system will occur in the region of $H / X=500$ nearly independent of enrichment.

Critical spherical radius searches were performed with XSDRNPM over the range of $H / X$ from about 100 to 700 . The critical radius, volume, mass of uranium, and mass of moderator for each system were calculated. The results are presented in Tables B.3 and B.4 and in Figs. 3 through 10. A minimum occurs for radius, volume, uranium mass, and moderator mass for each enrichment considered. The minimum values were inferred from Figs. 3 through 10 and are tabulated in Tables $I$ anu 2 and plotted in Figs. 11 and 12.

The estimated values for the infinite media multiplication, critical radius, volume, and mass presented in Tables 1 and 2 do not agree well with values previously calculated. The results of the previous calculations have been included in Appendix C. The results are in best agreement at 5\% enrichment and large $\mathrm{H} / \mathrm{X}$ values and get progressively worse as the enrichment and $\mathrm{H} / \mathrm{X}$ get smaller. A detailed review of both sets of data is presented in Sect. 3 of this report. 


\section{K-infirity vs $\mathrm{H} / \mathrm{X}$ for UO2F2-H2O}
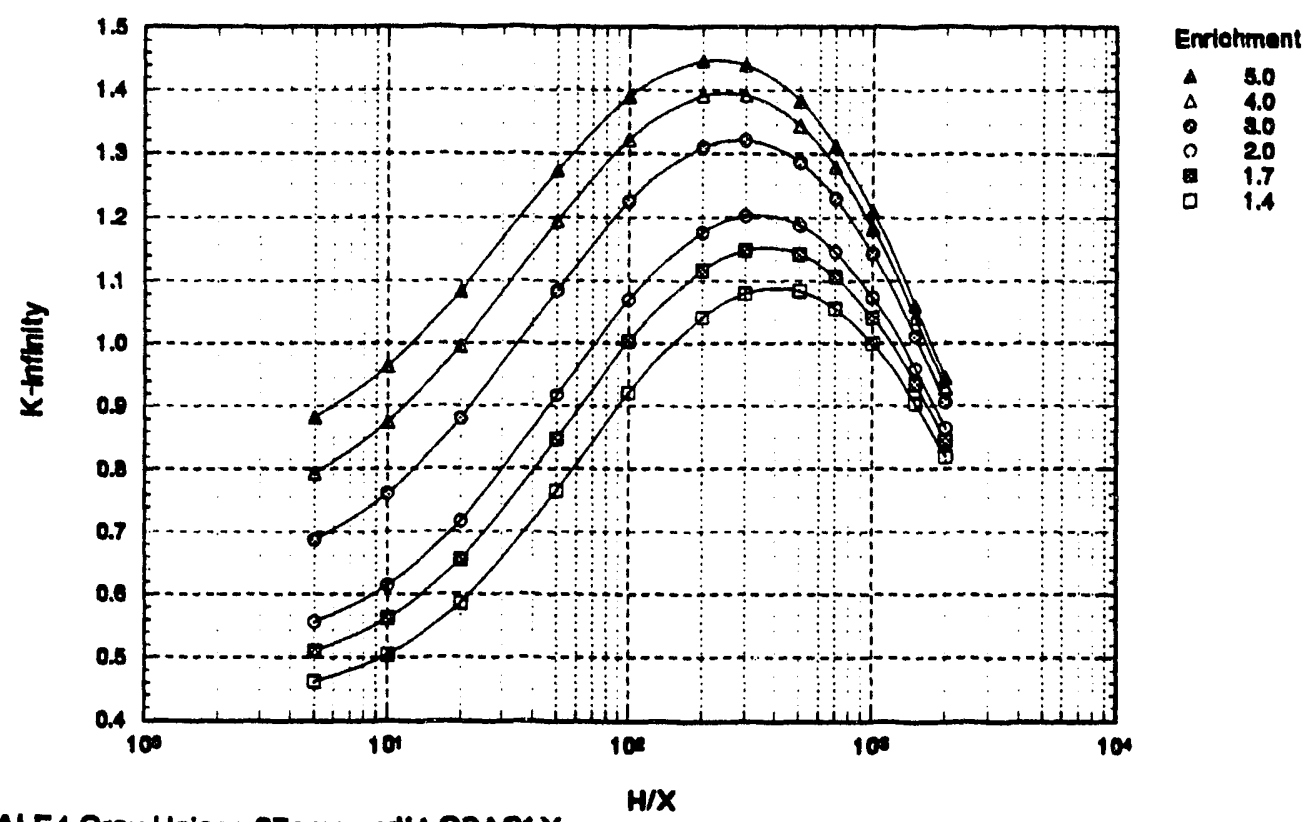

SCALE4 Cray Unicos 27groupndi4 C8A81X

Fig. 1. $\mathrm{k}$ vs $\mathrm{H} / \mathrm{X}$ for $\mathrm{UO}_{2} \mathrm{~F}_{2}-\mathrm{H}_{2} \mathrm{O}$.

NoT 10/20/92

\section{K-Infinity vs $\mathrm{H} / \mathrm{X}$ for UF6-HF}

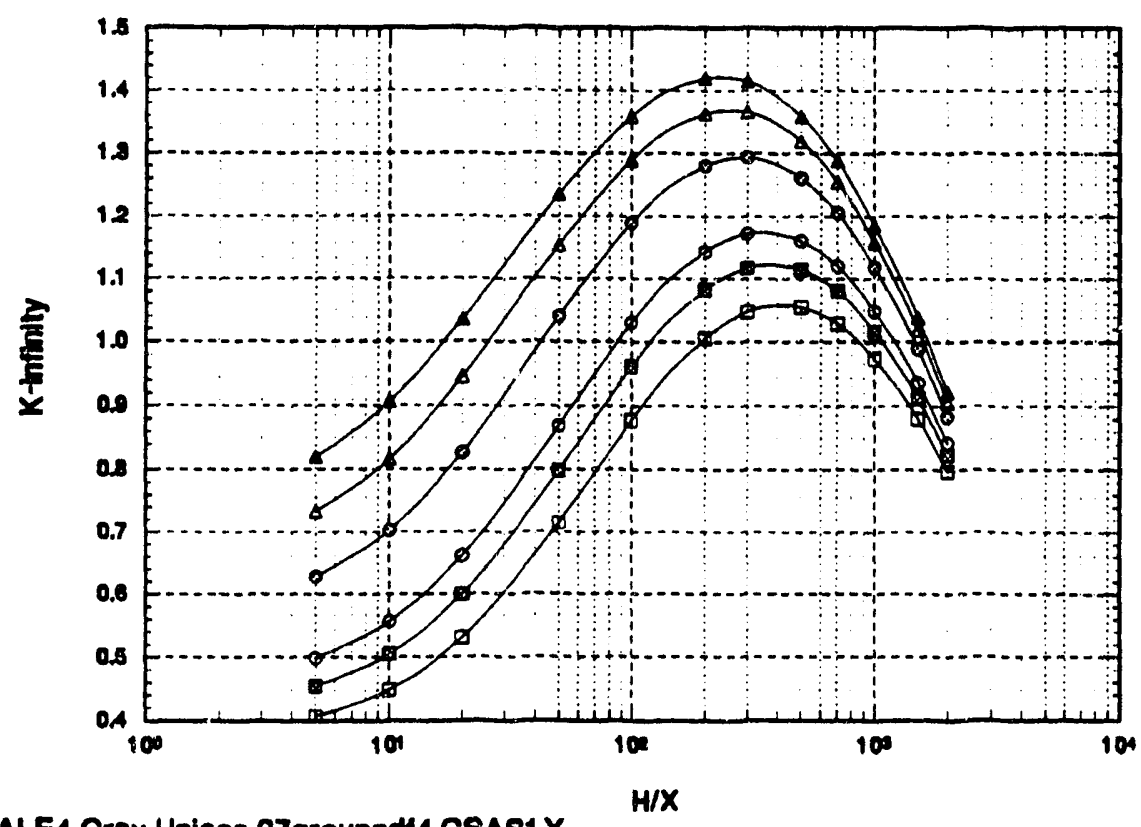

Fig. 2. $\mathrm{K}_{-}$vs $\mathrm{H} / \mathrm{X}$ for $\mathrm{UF}_{6}-\mathrm{HF}$. 


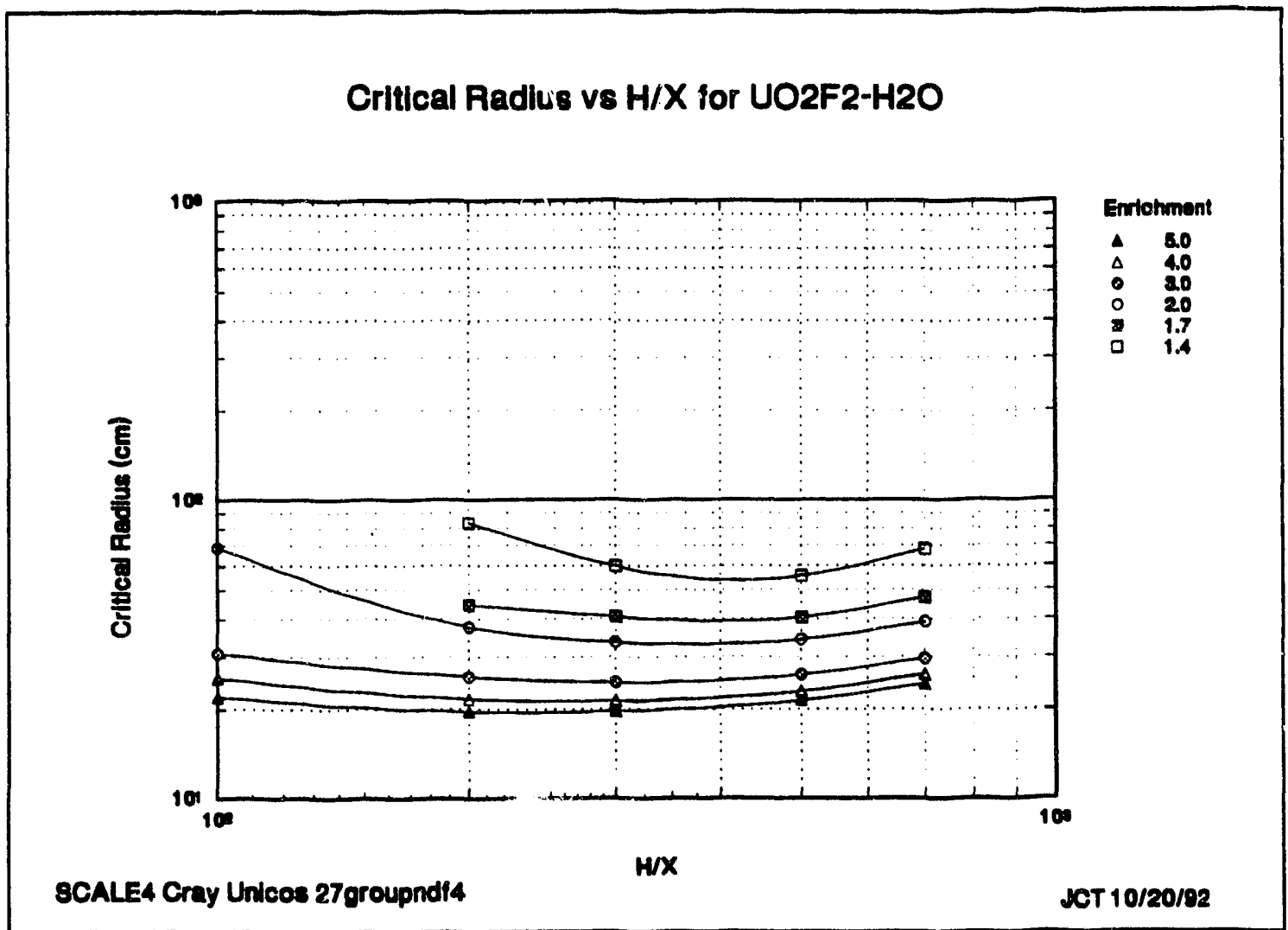

Fig. 3. Critical radius vs $\mathrm{H} / \mathrm{X}$ for $\mathrm{UO}_{2} \mathrm{~F}_{2}-\mathrm{H}_{2} \mathrm{O}$.

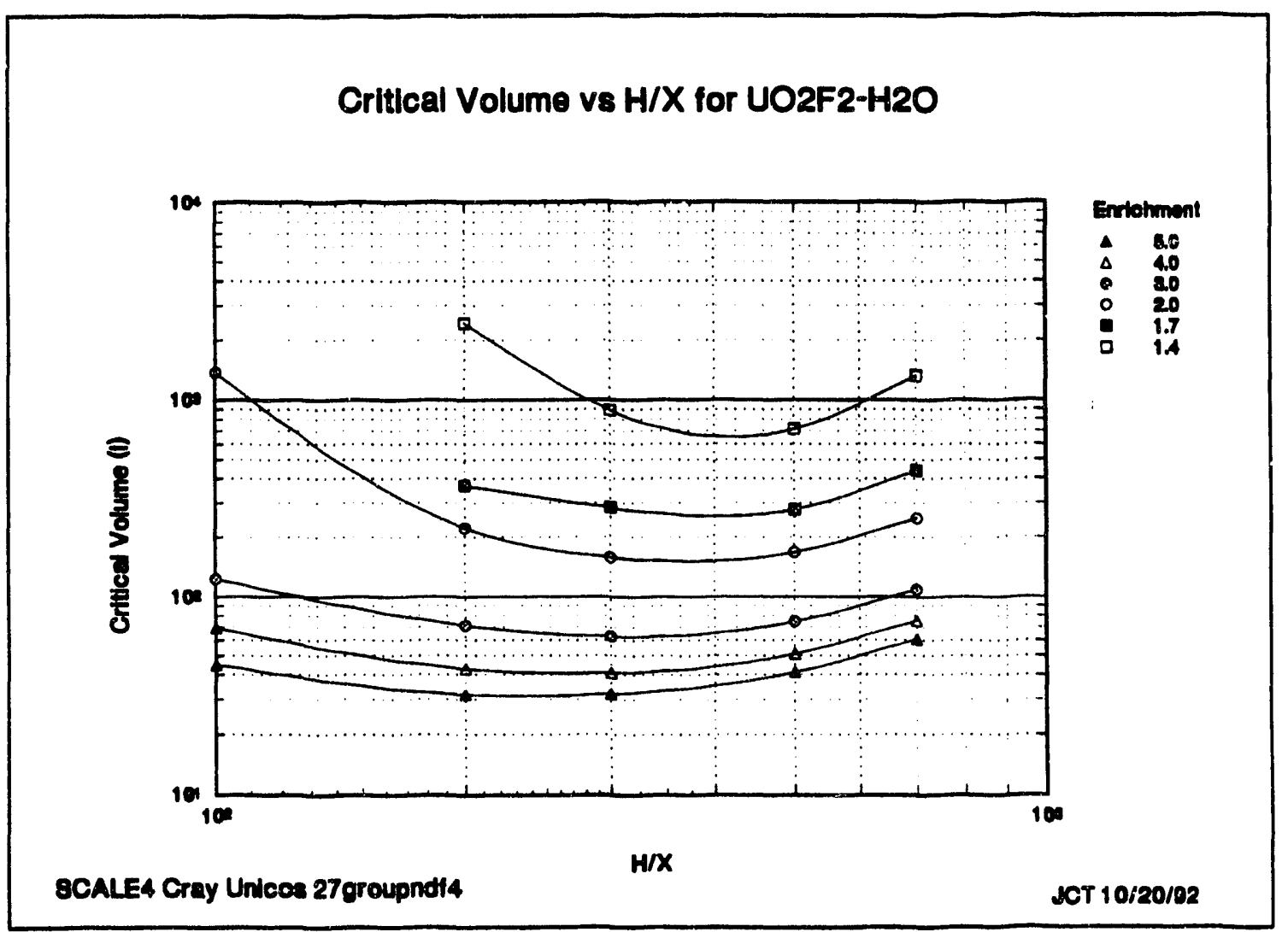

Fig. 4. Critical volume v8 $\mathrm{H} / \mathrm{X}$ for $\mathrm{UO}_{2} \mathrm{~F}_{2}-\mathrm{H}_{2} \mathrm{O}$. 


\section{Critical Mass U vs H/X for UO2F2-H2O}

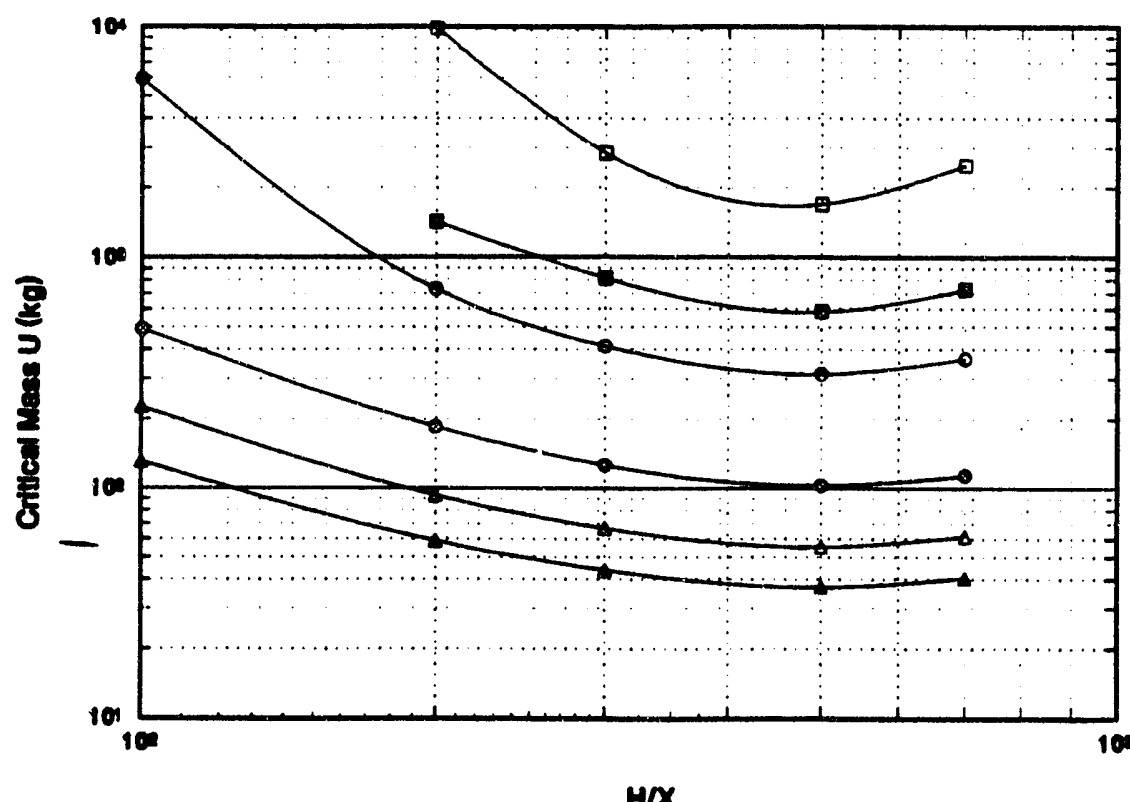

Encitiment

Fig. 5. Critical mass $\mathrm{U}$ vs $\mathrm{H} / \mathrm{X}$ for $\mathrm{UO}_{2} \mathrm{~F}_{2}-\mathrm{H}_{2} \mathrm{O}$.

\section{Mass of $\mathrm{H} 2 \mathrm{O}$ for Criticality vs $\mathrm{H} / \mathrm{X}$ for UO2F2-H2O}

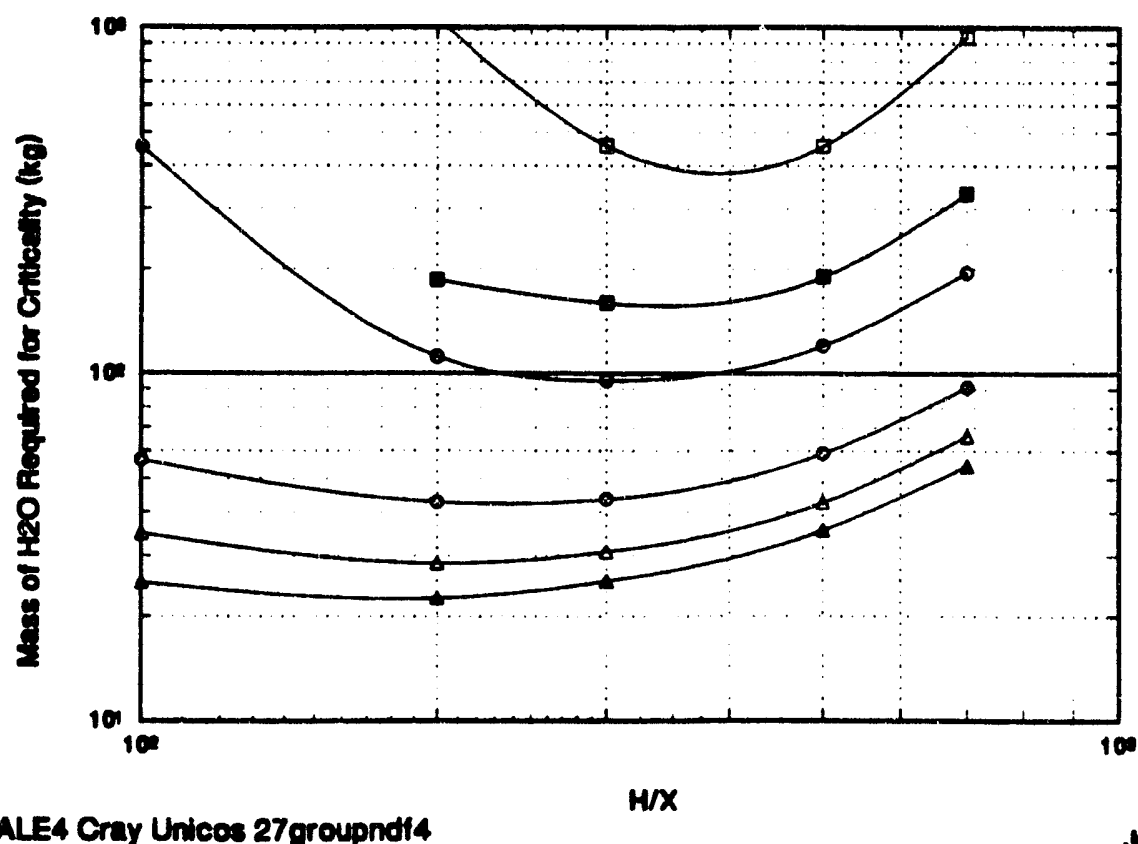

$\begin{array}{cc}\text { Enrtohmicen } \\ \Delta \quad 8.0 \\ \Delta & 4.0 \\ 0 & 8.0 \\ 0 & 2.0 \\ 0 & 1.7 \\ 0 & 1.4\end{array}$

Fig. 6. Mass of water for criticality vs $\mathrm{H} / \mathrm{X}$ for $\mathrm{UO}_{2} \mathrm{~F}_{2}-\mathrm{H}_{2} \mathrm{O}$. 


\section{Critical Radlus vs H/X for UF6-HF}
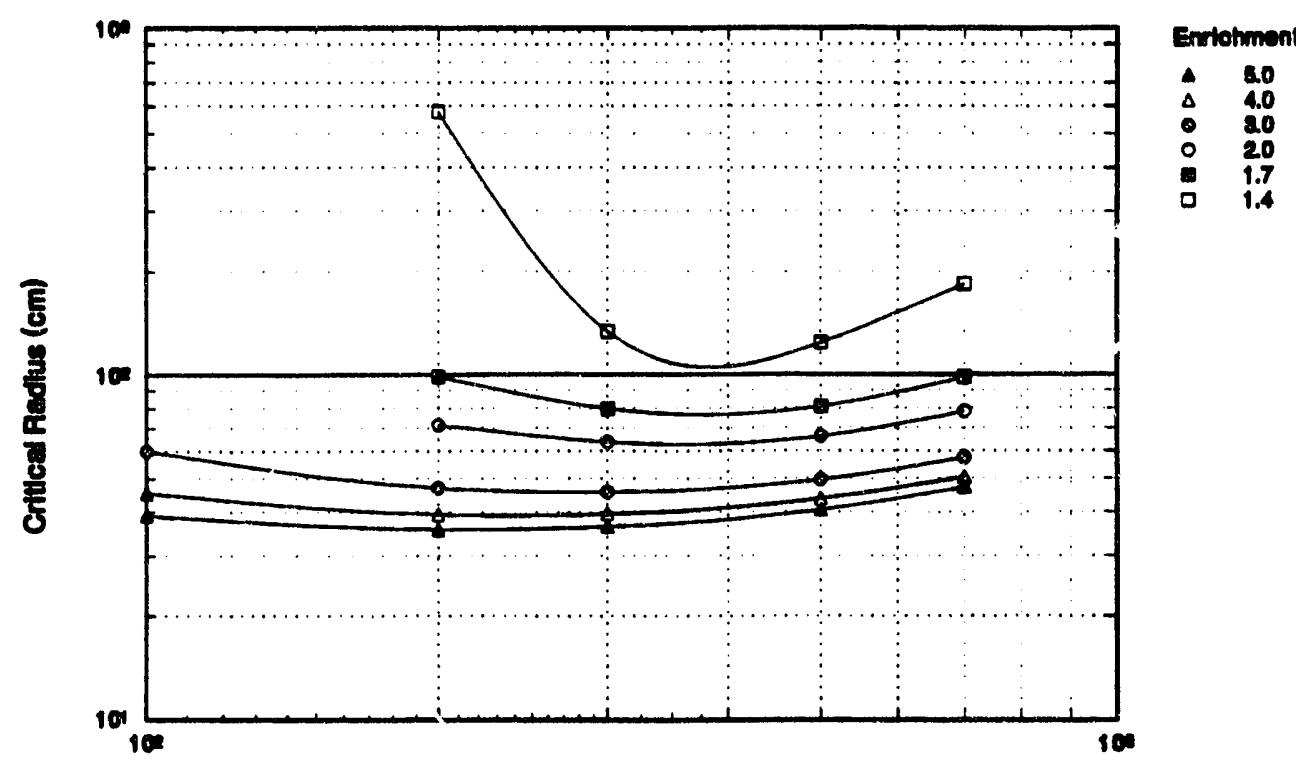

8CALE4 Cray Unicos 27groupndit4

$\mathrm{HX}$

LCT 10/20/02

Fig. 7. Critical radius vs $\mathrm{H} / \mathrm{X}$ for $\mathrm{UF}_{6}$-HF.

Critical Volume ve H/X for UF6-HF

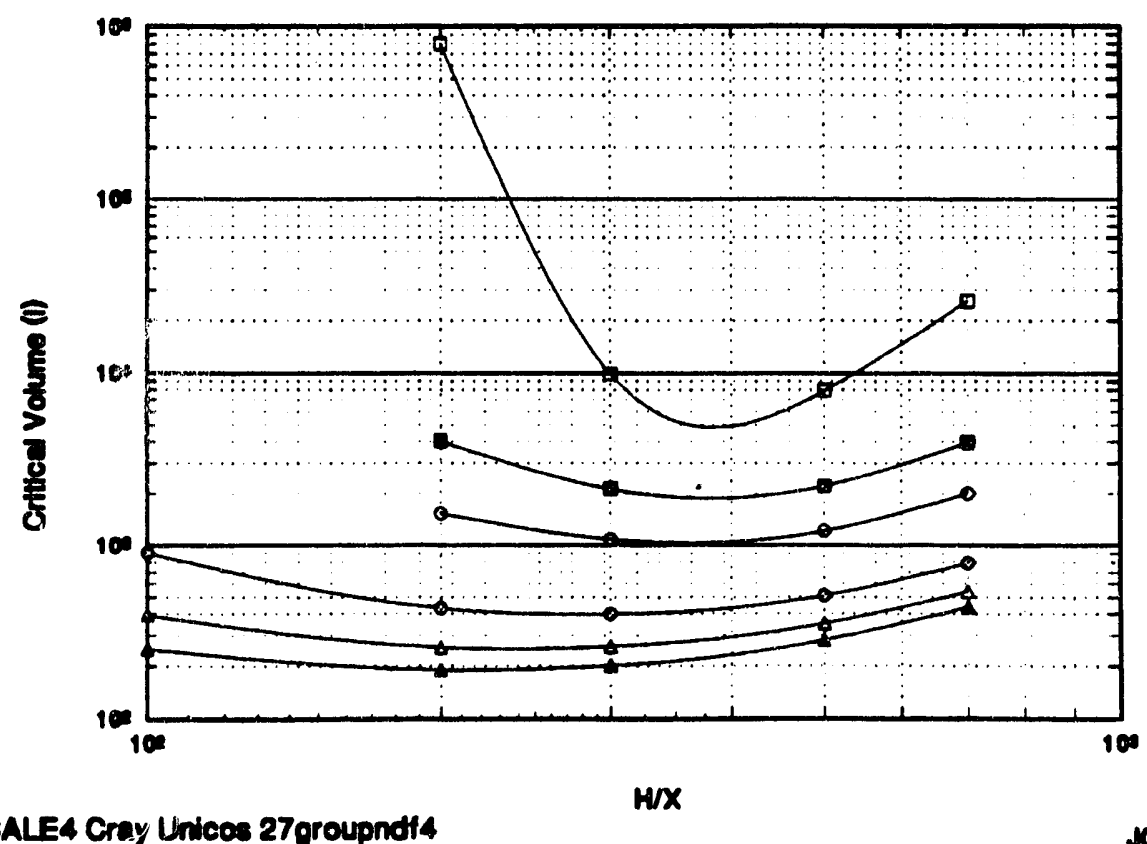

Entohinent

$\Delta \quad 80$

$\triangle \quad 40$

20

- 1.7 


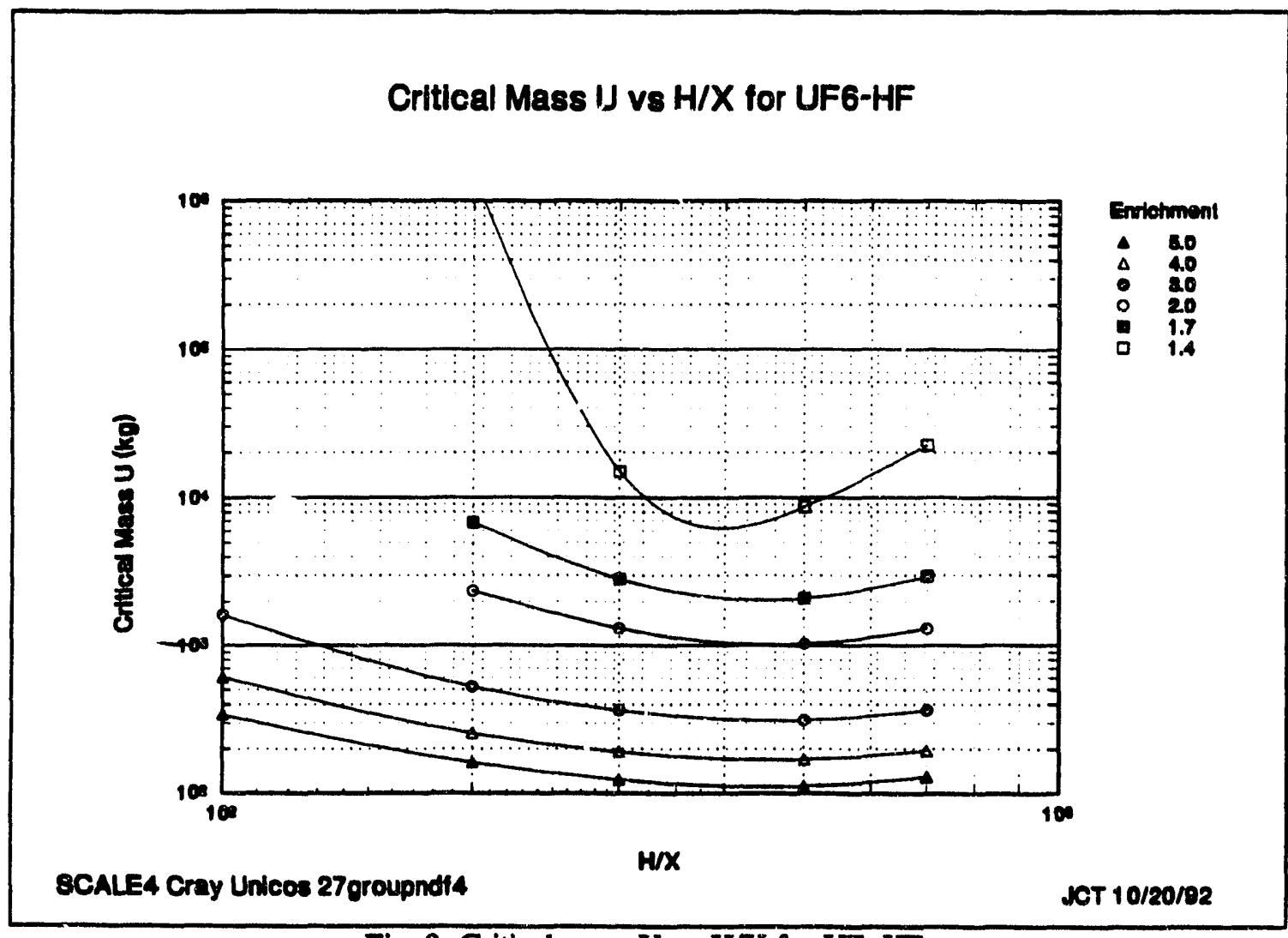

Fig. 9. Critical mass $U$ vs $H / X$ for $U F_{6}-H F$.

Masz of HF for Criticality ve H/X for UF6-HF

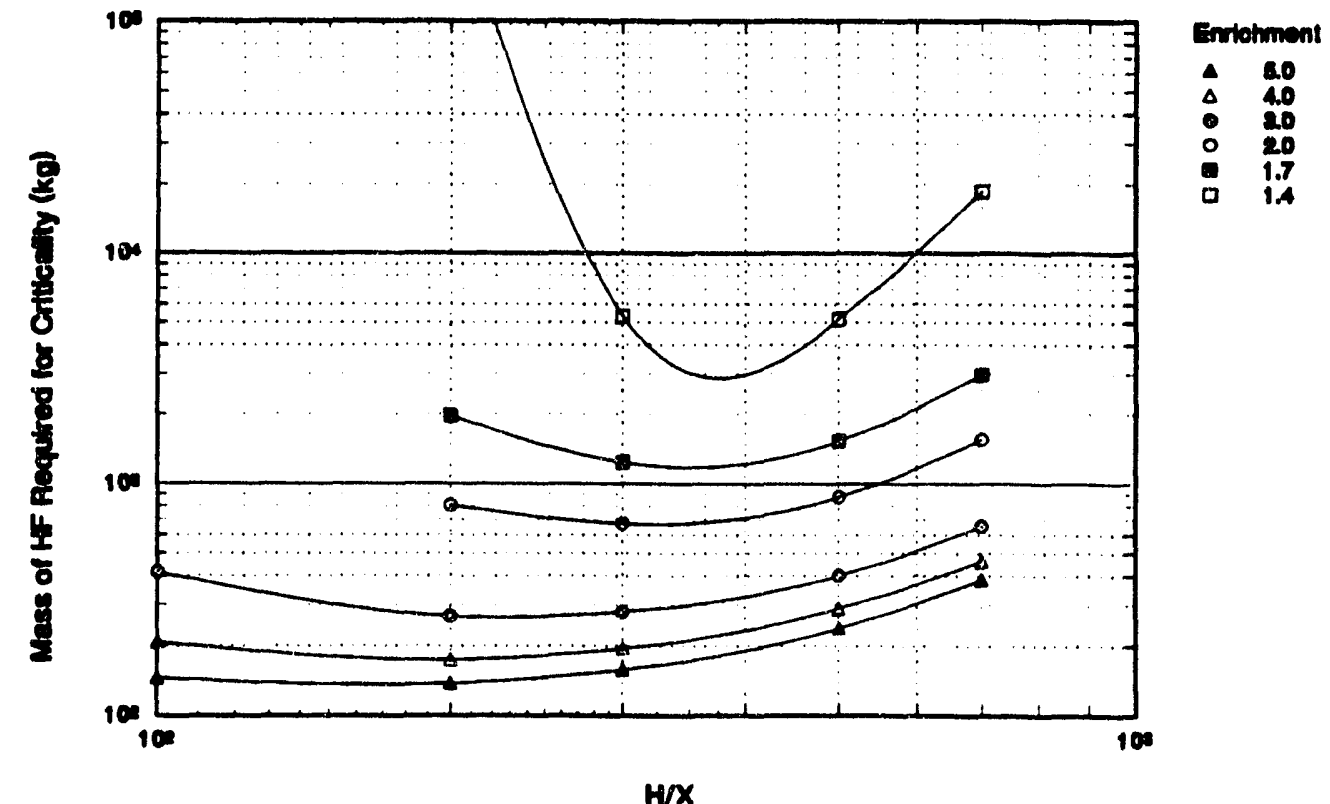

Fig. 10. Mass of HF for criticality vs $\mathrm{H} / \mathrm{X}$ for $\mathrm{UF}_{6}-\mathrm{HF}$. 
Table 1. Estimated minimum sritical parameters for $\mathrm{UO}_{2} \mathrm{~F}_{2}-\mathrm{H}_{2} \mathrm{O}$

\begin{tabular}{ccccc}
\hline Enrichment & $\begin{array}{c}\text { Minimum critical } \\
\text { radius (cm) }\end{array}$ & $\begin{array}{c}\text { Minimum critical } \\
\text { volume (l) }\end{array}$ & $\begin{array}{c}\text { Minimum } \\
\text { critical } \\
\text { U mass }(\mathrm{kg})\end{array}$ & $\begin{array}{c}\text { Minimum } \\
\text { critical } \\
\mathrm{H}_{2} \mathrm{O}(\mathrm{kg})\end{array}$ \\
\hline 5.0 & 19.6 & 31.5 & 37.0 & 22 \\
4.0 & 21.3 & 40.4 & 55.5 & 28 \\
3.0 & 24.6 & 62.3 & 102.0 & 42 \\
2.0 & 33.0 & 150.0 & 313.0 & 95 \\
1.7 & 40.0 & 268.0 & 581.0 & 157 \\
1.4 & 54.0 & 659.0 & 1698.0 & 405 \\
\hline
\end{tabular}

Table 2. Estimated minimum critical parameters for $\mathrm{UF}_{6}-\mathrm{HF}$

\begin{tabular}{ccccc}
\hline Enrichment & $\begin{array}{c}\text { Minimum critical } \\
\text { radius (cm) }\end{array}$ & $\begin{array}{c}\text { Minimum critical } \\
\text { volume (l) }\end{array}$ & $\begin{array}{c}\text { Minimum } \\
\text { critical } \\
\text { U mass (kg) }\end{array}$ & $\begin{array}{c}\text { Minimum critical } \\
\text { HF (kg) }\end{array}$ \\
\hline 5.0 & 35.6 & 188 & 105 & 135 \\
4.0 & 39.0 & 248 & 165 & 170 \\
3.0 & 45.0 & 381 & 310 & 265 \\
2.0 & 62.0 & 998 & 1000 & 670 \\
1.7 & 75.0 & 1760 & 2000 & 1200 \\
1.4 & 110.0 & 5570 & 7500 & 3600 \\
& & & & \\
\hline
\end{tabular}




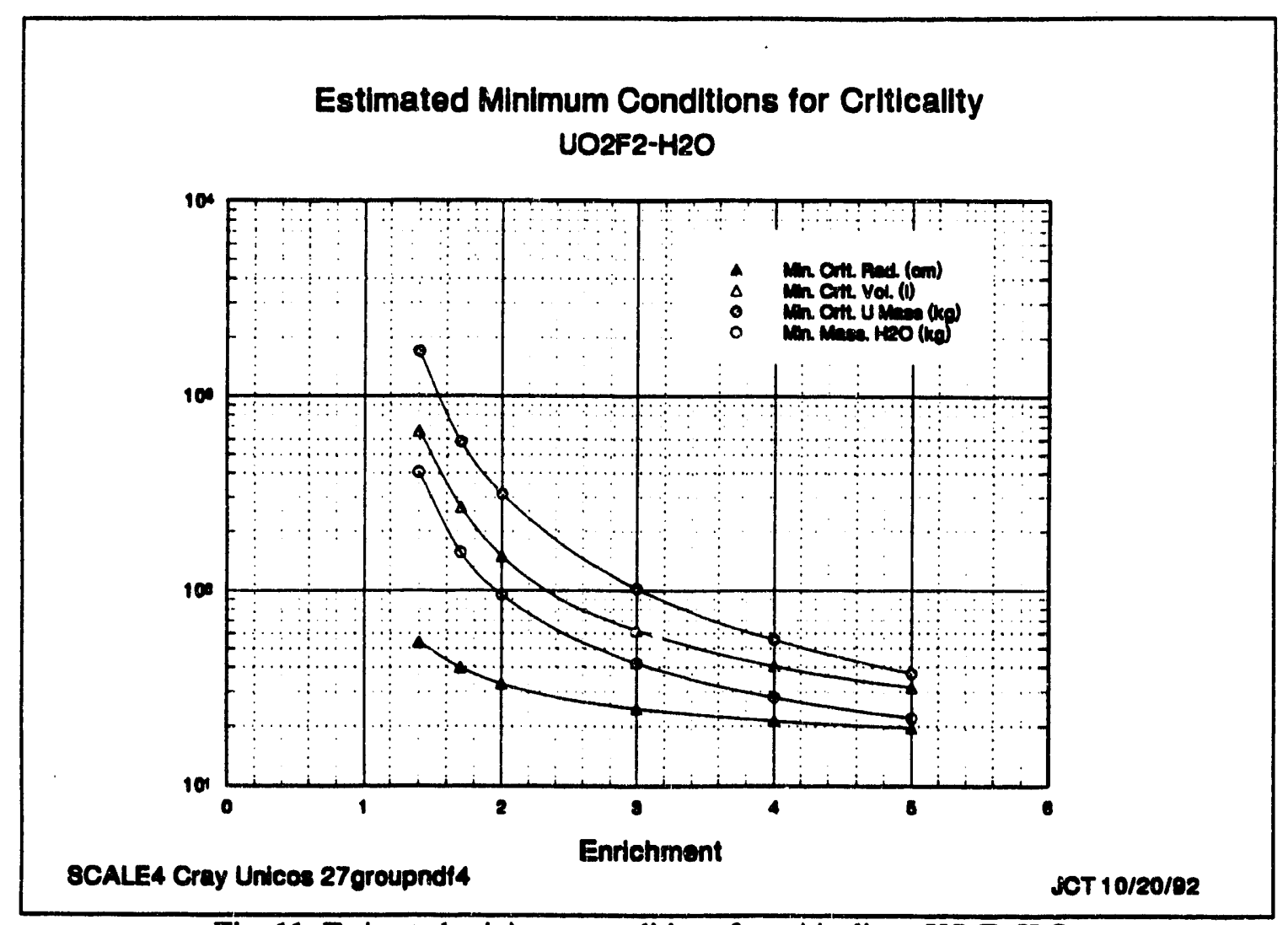

Fig. 11. Estimated minimum conditions for criticality - $\mathrm{UO}_{2} \mathrm{~F}_{2}-\mathrm{H}_{2} \mathrm{O}$.

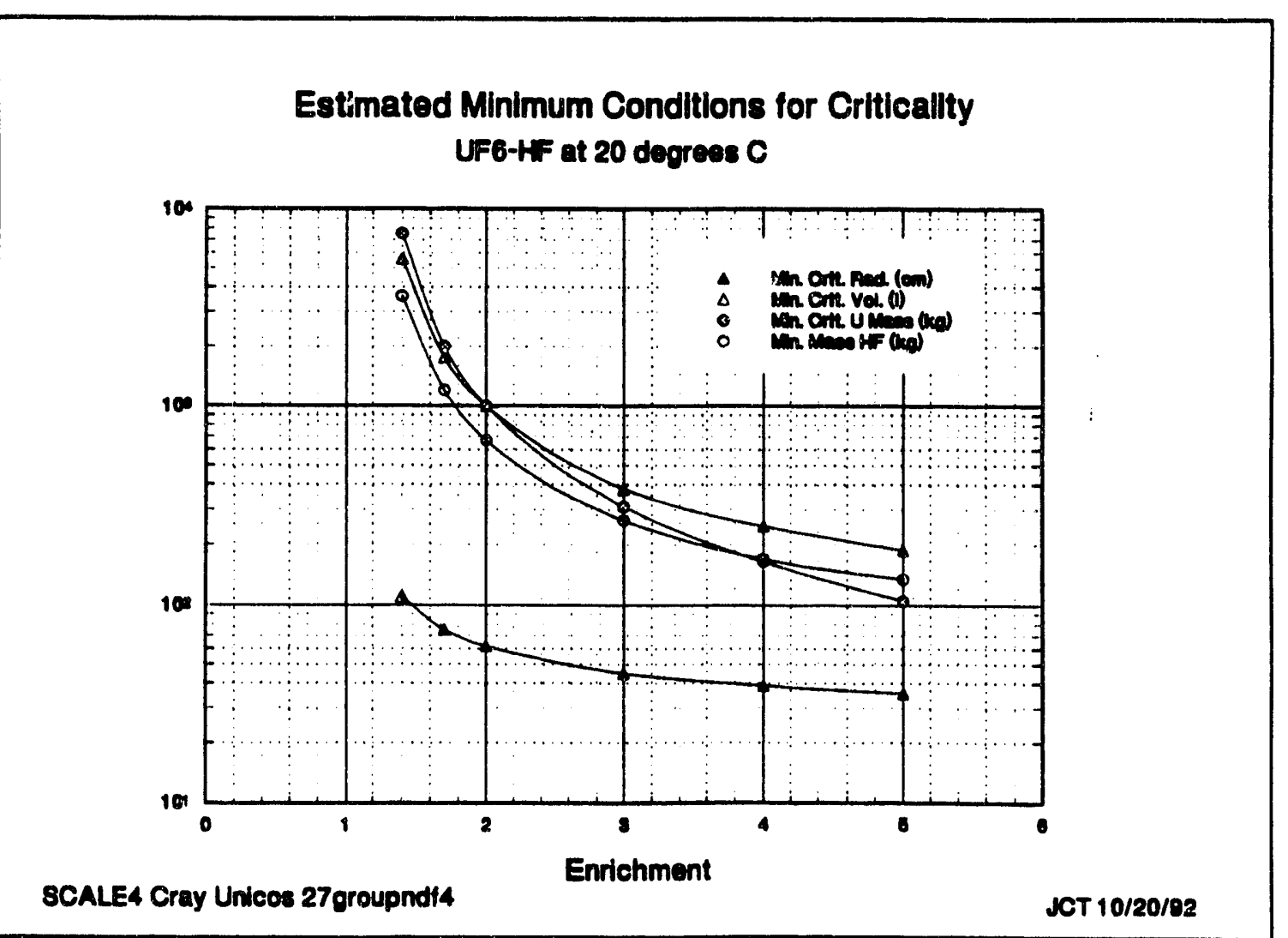

Fig. 12. Estimated minimum conditions for criticality - UF $-\mathrm{HF} @ 20^{\circ} \mathrm{C}$. 


\section{PROCEDURES FOR EXTENDING THE CALCULATED RESULTS}

The calculated minimum critical values presented in Tables 1 and 2 have a number of assumptions associated with them. These assumptions include the calculation of the physical properties of the system, the implied adequacy of the cross-section library used, and the fact that they were derived from critical systems (calculated $k_{\text {eff }}=1.0$ ). The ability to predict the effects of slight variations in these assumptions is useful. For example, a temperature of $20^{\circ} \mathrm{C}$ was used in this analysis. Estimates of the critical parameters for $\mathrm{UF}_{6}-\mathrm{HF}$ systems at a temperature of $0^{\circ} \mathrm{C}$ might be desired. Since the theoretical density of a system is a function of the temperature, estimates of $k_{\text {eff }}$ at a different temperature may be made by using the correspondent change in density. Another example might relate to the adequacy of the cross-section library. If one determines that there is a bias in the infinite media calculations, estimates of the effects on the critical parameters could be established by examining the relative change in $\mathrm{k}_{\mathrm{eff}}$ as a function of changes in $k_{\infty}$. As a final example, one may determine that they desire limits based on safely subcritical systems as opposed to critical systems. Estimates of a system that would yield a $k_{\text {eff }}$ of, for example, 0.95 may be made from calculational results of systems with a $k_{\text {eff }}=1.0$. The purpose of this sub-section is to briefly review the use of simple buckling theory in performing these estimates.

The effective multiplication of a fissile system may be estimated using the simple buckling relationship: $:^{19}$

$$
k_{\text {eff }}=\frac{k_{-}}{1+M^{2} B^{2}}
$$

where

$k_{\text {eff }}$ is the effective multiplication factor,

$k_{\infty}$ is the infinite media multiplication factor,

$\mathrm{M}^{2}$ is the neutron migration area,

$\mathrm{B}^{2}$ is the geometric buckling.

The infinite media multiplication factor and the neutron migration area are neutronic characteristics of the system under consideration. The geometric buckling is a function of the geometry and reflective conditions of the system. Equation (2) gives the geometric buckling for spherical geometry:

$$
B^{2}=\left(\frac{\pi}{R+\lambda}\right)^{2}
$$

where

$R$ is the radius of the sphere,

$\lambda$ is the reflector extrapolation distance. 
The extrapolation distance is an artificial quantity that is intended to account for the effects of a reflector. The extrapolation distance is a function of the physical form of the fissile material (fissile material compound, moderation ratio, enrichment, density, etc.) and the reflector material.

The effects of a change in the density of a system from $\rho_{0}$ to $\rho$ (where all of the constituents remain in the same relative ratios) may be estimated from the buckling relationship using the following assumptions:

1. $\mathbf{k}_{\infty}$ does not change as a function of density,

2. $\mathbf{M}^{2}$ is proportional to $\left(\rho_{0} / \rho\right)^{2}$ [i.e., $\mathbf{M}^{2}=\left(\rho_{0} / \rho\right)^{2} * \mathbf{M}_{0}^{2}$ ],

3. $\lambda$ is constant (i.e., $\lambda=\lambda_{0}$ ).

Under these assumptions the radius of the system at the new density is given by Eq. (3):

$$
R=\frac{P_{0}\left(R_{0}+\lambda_{0}\right)}{\rho}-\lambda .
$$

The zero-scripted values are those of the original system, and nonscripted values are those at the new conditions. Approximations such as Eq. (3) should be used with caution. This is particularly true because the assumptions may not be valid if the effects of large changes are being estimated. For example, the extrapolation distance, $\lambda$, cannot be treated as constant for estimations involving large density changes. Physically, this is related to the change in leakage of the system and to the effectiveness of the reflector in returning neutrons to more important regions of the system. As the density of the fissile material becomes smaller, leakage becomes larger. Reflected neutrons penetrate deeper before interacting. The effectiveness of the reflector increases because of these effects. The extrapolation distance for the new system which yields correct results is a function of the change in density similar to the migration area [i.e., $\lambda$ $\left.=\lambda_{0}^{*}\left(\rho_{0}^{\prime} n\right)^{c}\right]$, where $c$ could be on the order of 1.3 .

I. omc cases it may be desirable to estimate the effect of a change in $k_{00}$ on the critical radius or volume of a system. For example, one could estimate the change in critical geometry between two cross-section libraries which give slightly different values of $\mathrm{k}_{\infty}$ for the same system. Similarly, if a cross-section set is known or suspected to have a bias for a particular type of system, the impact of this bias on the predicted critical parameters may be estimated. The effects of a change in $\mathrm{k}_{\infty}$ may be approximated using the following assumptions:

1. $\mathbf{M}^{2}$ does not change, and

2. $\lambda$ is not a function of system size.

Under these assumptions the radius of the system with the modified infinite media multiplication factor may be estimated using Eq. (4): 


$$
R=\left(\frac{k_{\infty}^{0}-1}{k_{\infty}-1}\right)^{\frac{1}{2}}\left(R_{0}+\lambda\right)-\lambda
$$

It may also be desirable to estimate the critical parameters of a system that has an effective multiplication different than that calculated. For example, critical parameters (values for $\mathrm{k}_{\mathrm{eff}}=1.0$ ) may have been calculated, and the parameters that correspond to a $\mathrm{k}_{\mathrm{eff}}=0.95$ or 0.90 may be desired. The radius of a system for a different value of the effective multiplication factor may be estimated using Eq. (5):

$$
R=\left(R_{0}+\lambda\right)\left(\frac{k_{e f f}\left(k_{\infty}-k_{e f f}^{0}\right)}{k_{e f f}^{0}\left(k_{\infty}-k_{e f f}\right)}\right)^{\frac{1}{2}}-\lambda
$$

The relationships given in Eqs. (3) through (5) are approximate, but they are useful in estimating the effects of small perturbations on a particular system. An estimate of the extrapolation distance of about $6.5 \mathrm{~cm}$ may be used over the $\mathrm{H} / \mathrm{X}$ range of 100 to 700 for the low-enriched systems considered in this report. ${ }^{19}$

An interesting observation may be made if Eq. (5) is used to evaluate the change in the radius for a decrease in $k_{\text {eff }}$ from 1.0 to 0.95 . The magnitude of the change in the radius is sensitive to the infinite media multiplication of the system under consideration. For example, if the infinite media multiplication factor is 1.01 , the new radius would be only $40 \%$ of the radius, which gave a $\mathbf{k}_{\mathrm{eff}}=1.0$. If $\mathbf{k}_{\infty}=1.1$, the new radius would be about $80 \%$ of the original radius. If $k_{\infty}=2.0$, the new radius would be about $95 \%$ of the original. Basing the criticality safety of a system on a calculated $k_{\text {eff }}$ of 0.95 (or any other arbitrary value), independent of the characteristics of the system, places a tremendous conservatism on the systems with an already low reactivity. The use of a safety factor on the critical geometry (a 5 or $10 \%$ reduction) would seem a reasonable alternative to using a margin of subcriticality on calculated $k_{\text {eff }}$ -

Equation (4) indicates that the critical radius is also more sensitive to a change in the infinite media multiplication factor for systems with smaller values of $k_{\infty}$ than for systems that have a large infinite media multiplication. A $1 \%$ uncertainty in the infinite media multiplication around a value of $\mathrm{k}_{\infty}=1.01$ would yield a change in radius of $0.25 \mathrm{R}_{0}<\mathrm{R}<\infty$. A similar uncertainty for $k_{\infty}=1.1$ yields a change in radius of $0.81 R_{0}<R<1.26 R_{0}$; a value of $k_{\infty}=2.0$ yields a change of $0.96 R_{0}<R<1.04 R_{0}$. The smaller the infinite media multiplication, the more precise the cross sections, computational techniques, and experimental benchmarks have to be to reasonably predict values for critical radius, volume, and mass. 


\section{INVESTIGATION OF A CALCULATIONAL DISCREPANCY}

The results presented in Sect. 2 did not agree well with those of a similar analysis performed in 1983 using the ANISN code and the Knight-modified Hansen-Roach 16-group cross sections. For reference purposes, the results of the 1983 analysis are presented in Appendix C. There are significant differences in the predicted infinite media multiplication, critical radius, volume, and mass which appear to be a function of enrichment and moderation ratio. The disagreement is of considerable interest for several reasons.

The results of the 1983 analysis were checked against published data available at the time they were performed. Both the critical data for low-enriched uranium presented in TID-7028 ${ }^{20}$ and the subcritical data presented in TID-7016 21 and "safe" values presented in K-101922 tend to support the original calculations. Differences of as large as $10 \%$ in the infinite media multiplication factor were observed between the 1983 calculations and those presented in Sect. 2. If the 1983 calculations are taken as correct, then one must conclude that the results from the SCALE-4.0 calculations using the 27-group ENDF/B-IV library are substantially nonconservative.

Both the ANISN code with the Knight-modified Hansen-Roach cross sections and the XSDRNPM code with the SCALE 27-group library have been used extensively and validated against the same set of critical experiments. Even though each of the cross-section libraries have shown indications of bias, there has been no evidence to suggest that there should be a significant inadequacy in either code or cross-section library. It was not expected that there would be as large as a $10 \%$ difference in the calculated infinite media multiplication factors for the type of system analyzed here. Since previous validations against the same experiments have not indicated such large differences between the codes and libraries, the discrepancy strongly suggests that there has been inadequate validation and that the codes and cross sections are being used outside the range of validation in this analysis.

The determination as to which calculations are more reliable is not easy in the absence of directly related critical experiment benchmarks. The purpose of this section is to identify which calculations appear to be inadequate. Three separate comparisons were performed toward this end. Each is discussed separately below.

\subsection{COMPARISON WTTH OTHER CROSS-SECTION LIBRARIES}

The input data and calculational methodology used in the 1983 analysis were reviewed to determine if there were any errors or significant differences in the problem being solved. It was determined that there were differences in the formulations used to specify mixture densities.

The calculated densities for the $\mathrm{UO}_{2} \mathrm{~F}_{2}-\mathrm{H}_{2} \mathrm{O}$ systems were similar except at $\mathrm{H} / \mathrm{U}$ values less than 4. The density formulation given for $\mathrm{UO}_{2} \mathrm{~F}_{2}$ in Appendix $\mathrm{A}$ is discontinuous at an $\mathrm{H} / \mathrm{U}$ $=4$ in order to conservatively account for mixtures of hydrates that may exist below this 
mociration level. The formulation used in 1983 is potentially nonconservative for systems below an $\mathrm{H} / \mathrm{U}=4$.

The calculated densities for $\mathrm{UF}_{6}-\mathrm{HF}$ systems were considerably different. It was determined that the calculations performed in 1983 were based on a temperature of $-100^{\circ} \mathrm{F}$ $\left(-73.3^{\circ} \mathrm{C}\right)$. The theoretical density for $\mathrm{UF}_{6}$ and $\mathrm{HF}$ are $9.5 \%$ and $23.6 \%$ larger, respectively, at $-73.3^{\circ} \mathrm{C}$ when compared with the theoretical dersities at $20^{\circ} \mathrm{C}$ used in Sect. 2.

In addition, the 1983 calculations were set up using the KENO-IV $\sigma_{p}$ methodology. No interpolation was performed between $\sigma_{p}$ values for the ${ }^{215} U$ and ${ }^{238} U$ cross sections; the nearest $\sigma_{p}$ cross-section set below the calculated value was chosen for ${ }^{238} \mathrm{U}$, and the nearest set above was chosen for ${ }^{235} \mathrm{U}$. This methodology yields a conservative result with respect to actually interpolating between sets. The 1983 analysis was performed with ANISN as opposed to XSDRNPM.

The differences in the density help explain some of the observed difference in the estimated critical parameters between the current calculations and those performed in 1983,

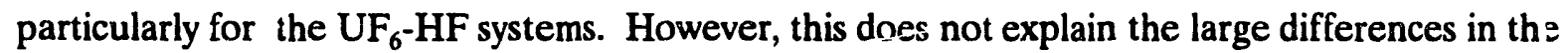
calculated infinite media multiplication. The infinite media multiplication is a function of the: relative ratios of the materials in the fissile system and is independent of the density of the system. Since the infinite media multiplication calculations revealed the largest differences, infinite $\mathrm{UO}_{2} \mathrm{~F}_{2}-\mathrm{H}_{2} \mathrm{O}$ systems were chosen for further analysis.

All the infinite media systems in Sect. 2 were recalculated using SCALE-4.0 and the SCALE 16-group library. This eliminated the differences in density, built-in conservatism, and codes used. In addition, all the infinite media systems were recalculated using SCALE-4.0, and a preliminary version of the LAW-238 ENDF/B-V fine-group cross-section library was generated at ORNL. The results of these calculations are given in Tables D.1 through D.4. The results of each series of calculations is also presented as $k_{\infty}$ versus $\mathrm{H} / \mathrm{X}$ at each enrichment in Figs. 13 through 22.

The differences in calculated $k_{\infty}$ between the 1983 calculations using the Knight-modified Hansen-Roach cross sections and the current calculations using the SCALE 16-group library are relatively minor (on the order of 1\%), as can be seen in Figs. 13 through 22. The 1983 calculations (labeled as KMHR) appear to be slightly conservative with respect to the SCALE 16-group calculations for both the $\mathrm{UO}_{2} \mathrm{~F}_{2}-\mathrm{H}_{2} \mathrm{O}$ and $\mathrm{UF}_{6}-\mathrm{HF}$ systems. This indicates that there is not a significant difference between the two versions of the Knight-modified Hansen-Roach cross sections. It also indicates that there are not significant differences between the ANISN and XSDRNPM codes.

Both the Knight-modified Hansen-Roach and the SCALE 16-group cross sections overpredict the infinite media multiplication factor compared with the SCALE 27-group library. There appears to be a trend between the Knight-modified Hansen-Roach cross sections and the 27-group library which is a function of both the enrichment and $H / X$. The calculations performed with the LAW 238-group library tend to consistently fall 0.5 to $1 \%$ higher than the SCALE 27-group calculations. (These differences appear to be consistent with the changes 


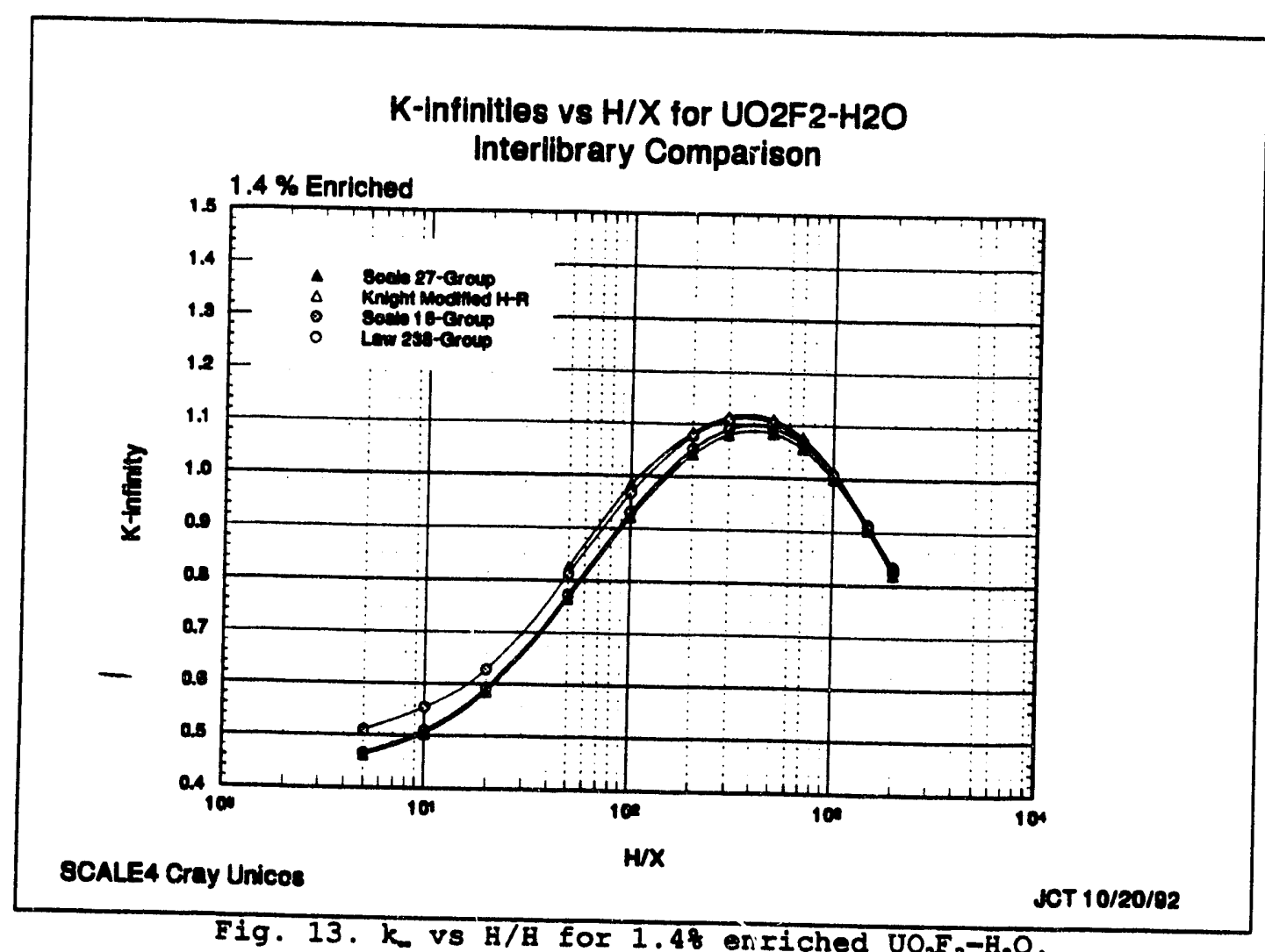

Fig. 13. $\mathrm{K}$ vs $\mathrm{H} / \mathrm{H}$ for 1.48 en riched $\mathrm{UO}_{2} \overline{\mathrm{F}}_{2}-\mathrm{H}_{2} \mathrm{O}$.
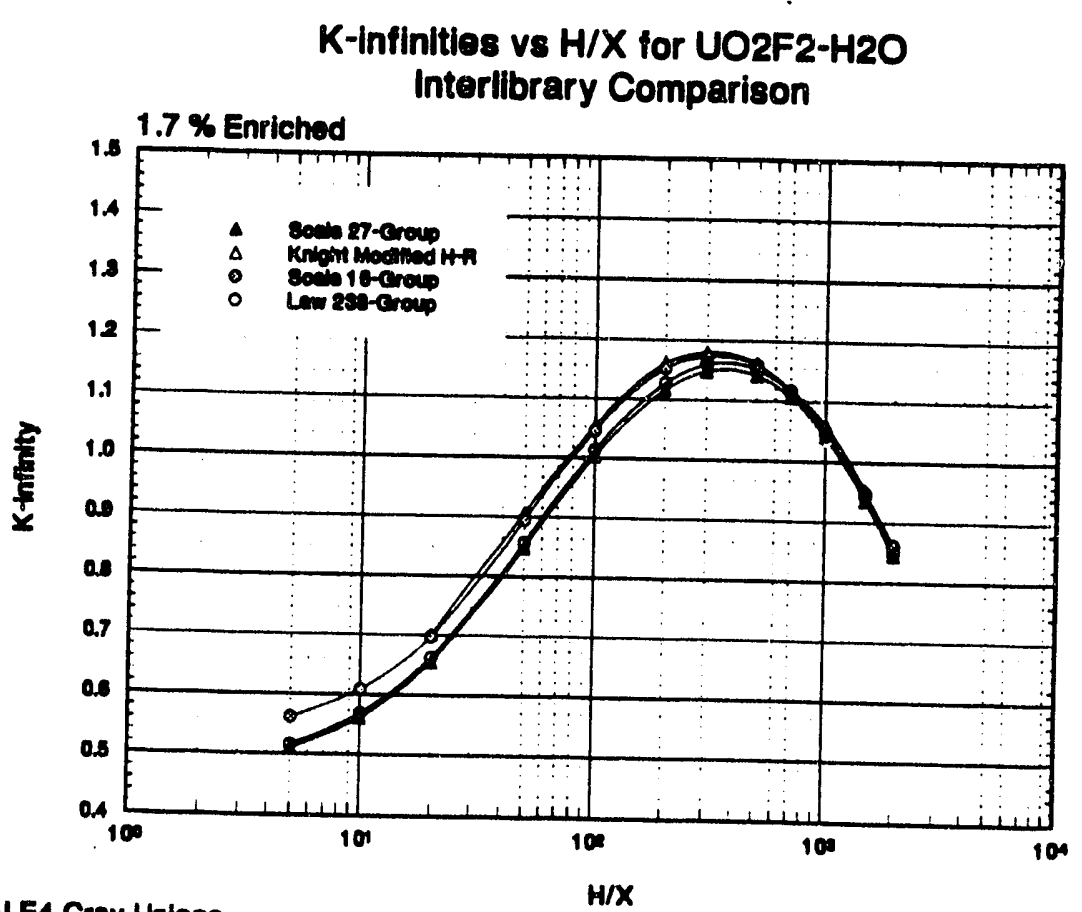

8CALE4 Cray Unicos

NCT 10/20/02

Fig. 14. $k$ vs $\mathrm{H} / \mathrm{X}$ for 1.7 enriched $\mathrm{UO}_{2} \mathrm{~F}_{2}-\mathrm{H}_{2} \mathrm{O}$. 


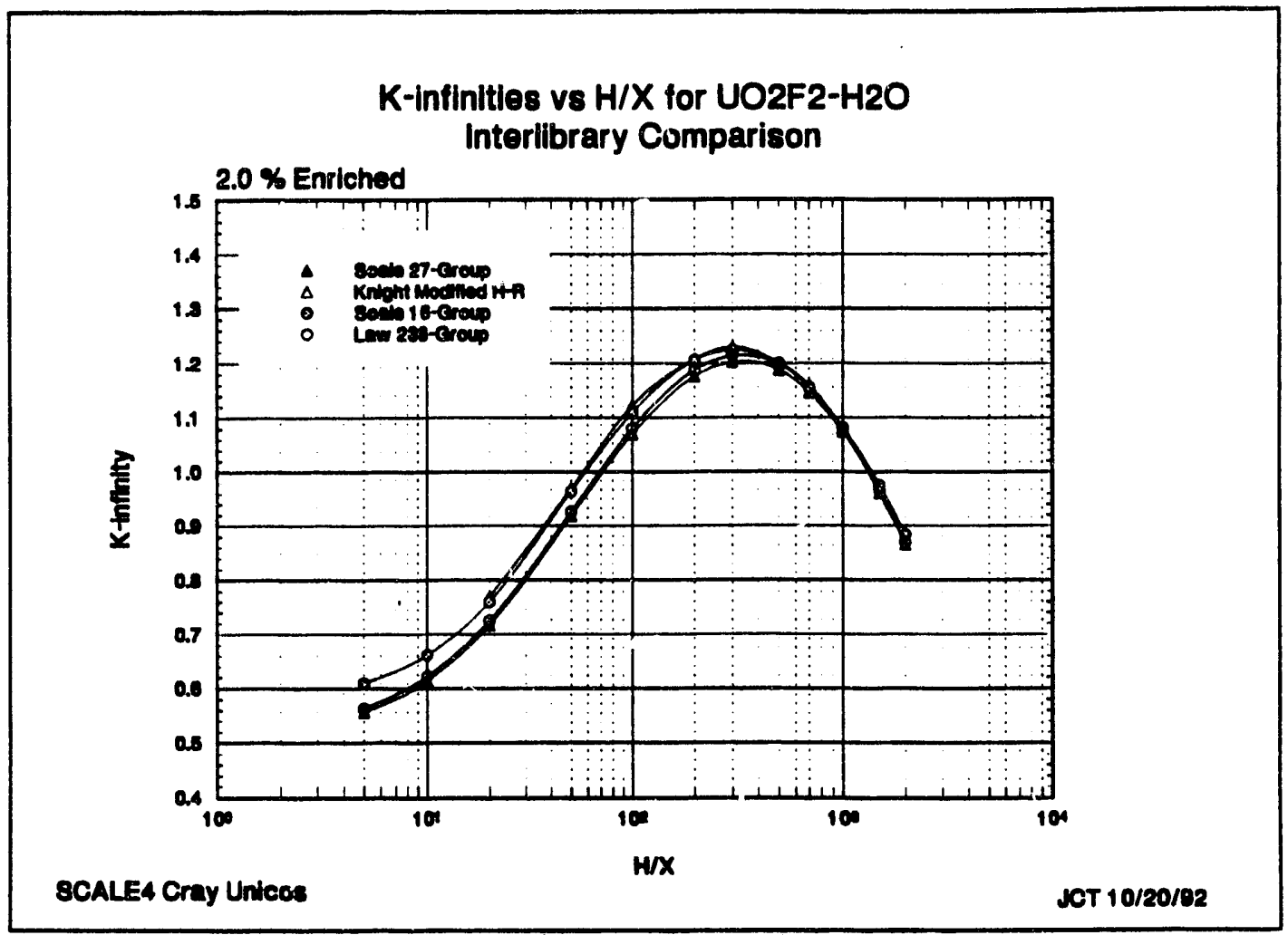

Fig. 15. $k$ vs $\mathrm{B} / \mathrm{X}$ for 28 enriched $\mathrm{OO}_{2} \bar{F}_{2}-\mathrm{H}_{2} \mathrm{O}$.

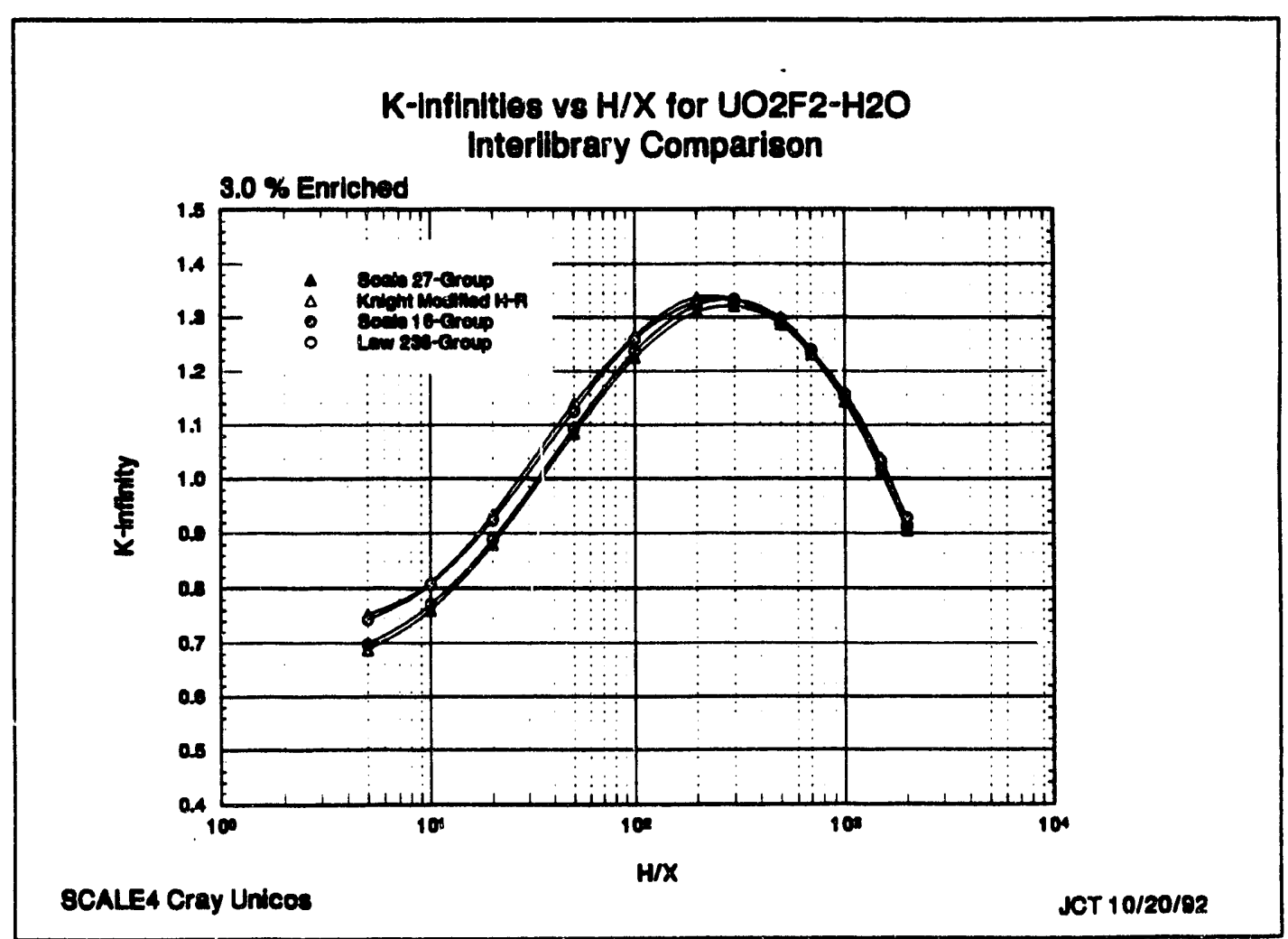

Fig. 16. $k_{n}$ vs $\mathrm{H} / \mathrm{X}$ for $3 \frac{8}{8}$ enriched $\mathrm{UO}_{2} \mathrm{~F}_{2}-\mathrm{H}_{2} \mathrm{O}$. 


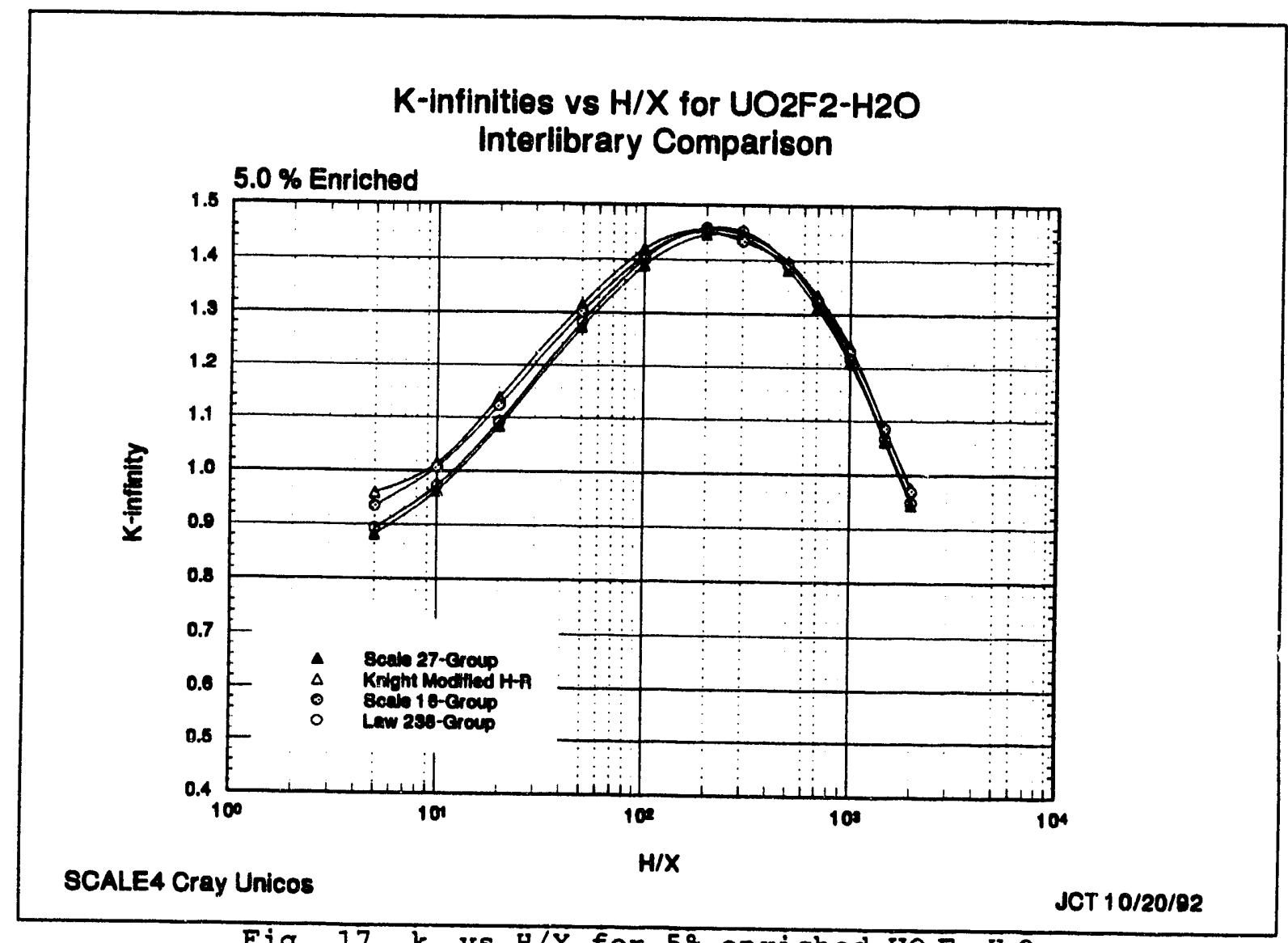

Fig. 17. $\mathrm{k}_{m}$ vs $\mathrm{H} / \mathrm{X}$ for $5 \frac{8}{8}$ enriched $\mathrm{UO}_{2} \bar{F}_{2}-\mathrm{H}_{2} \mathrm{O}$. 


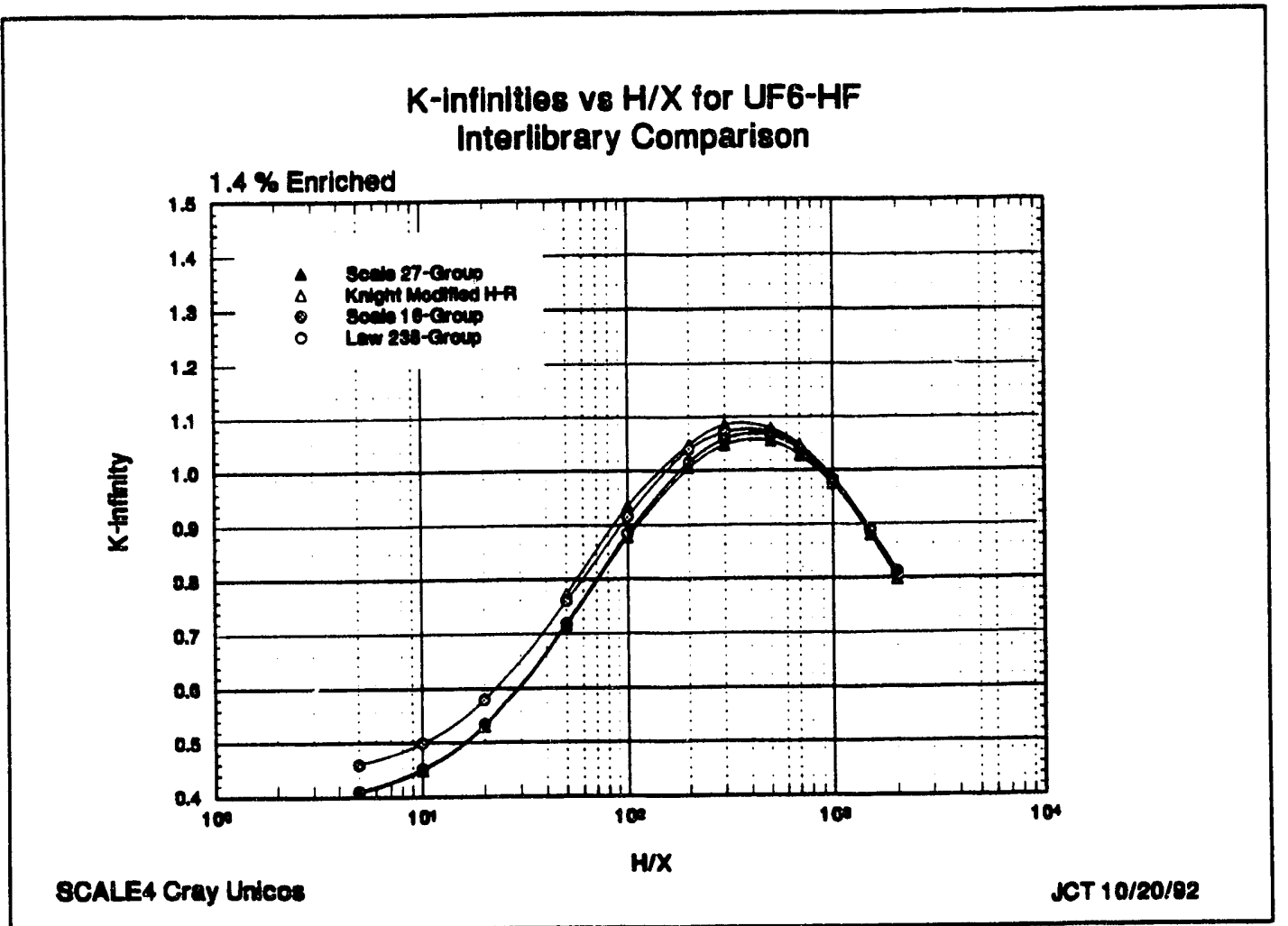

Fig. 18. k v8 A/E for 1.48 enriched UF - HF.

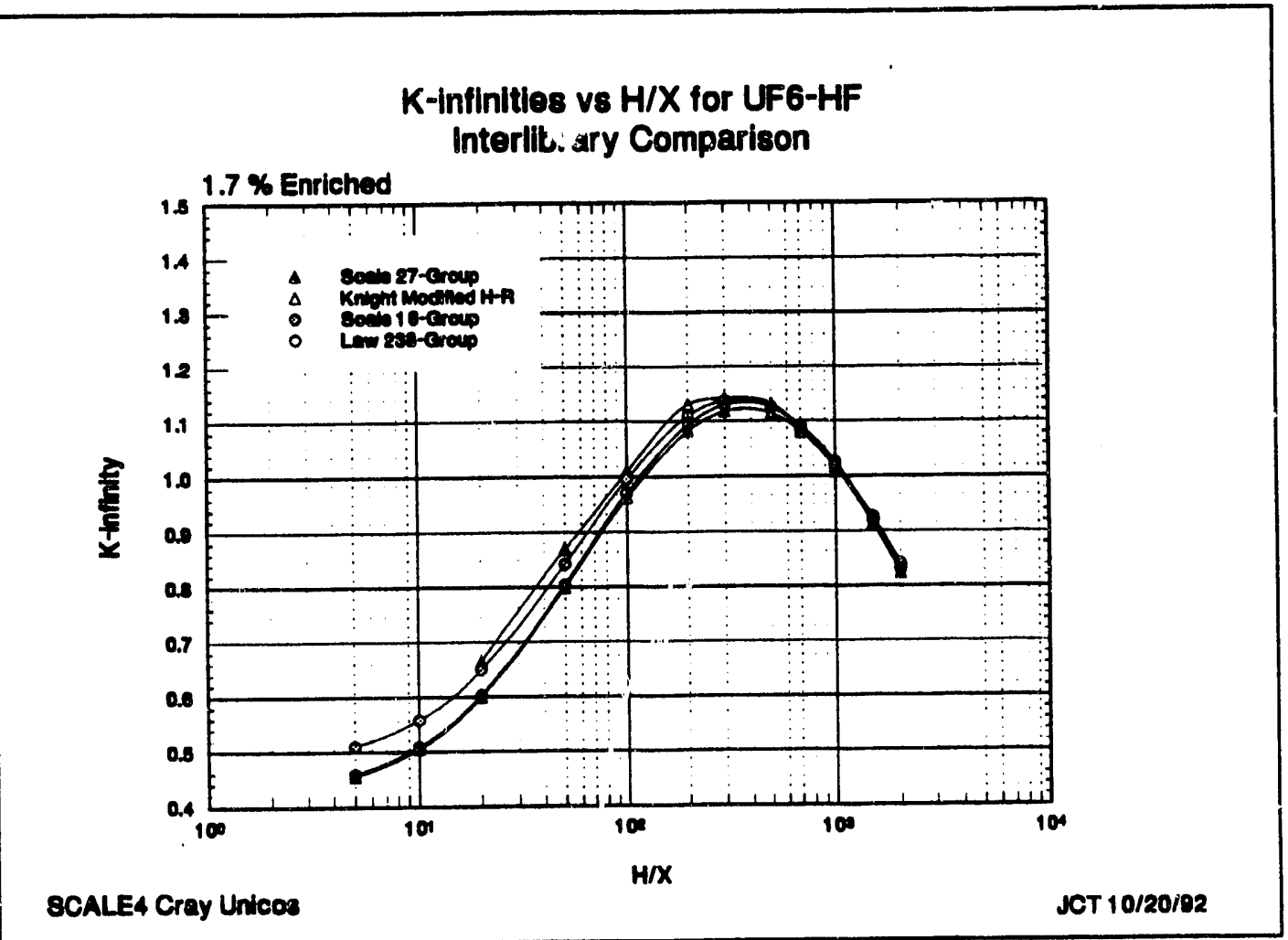

Fig. 19. $\mathrm{K}_{6}$ v8 $\mathrm{H} / \mathrm{X}$ for $1.7 \%$ enriched $\mathrm{UF}_{6}-\mathrm{HF}$. 


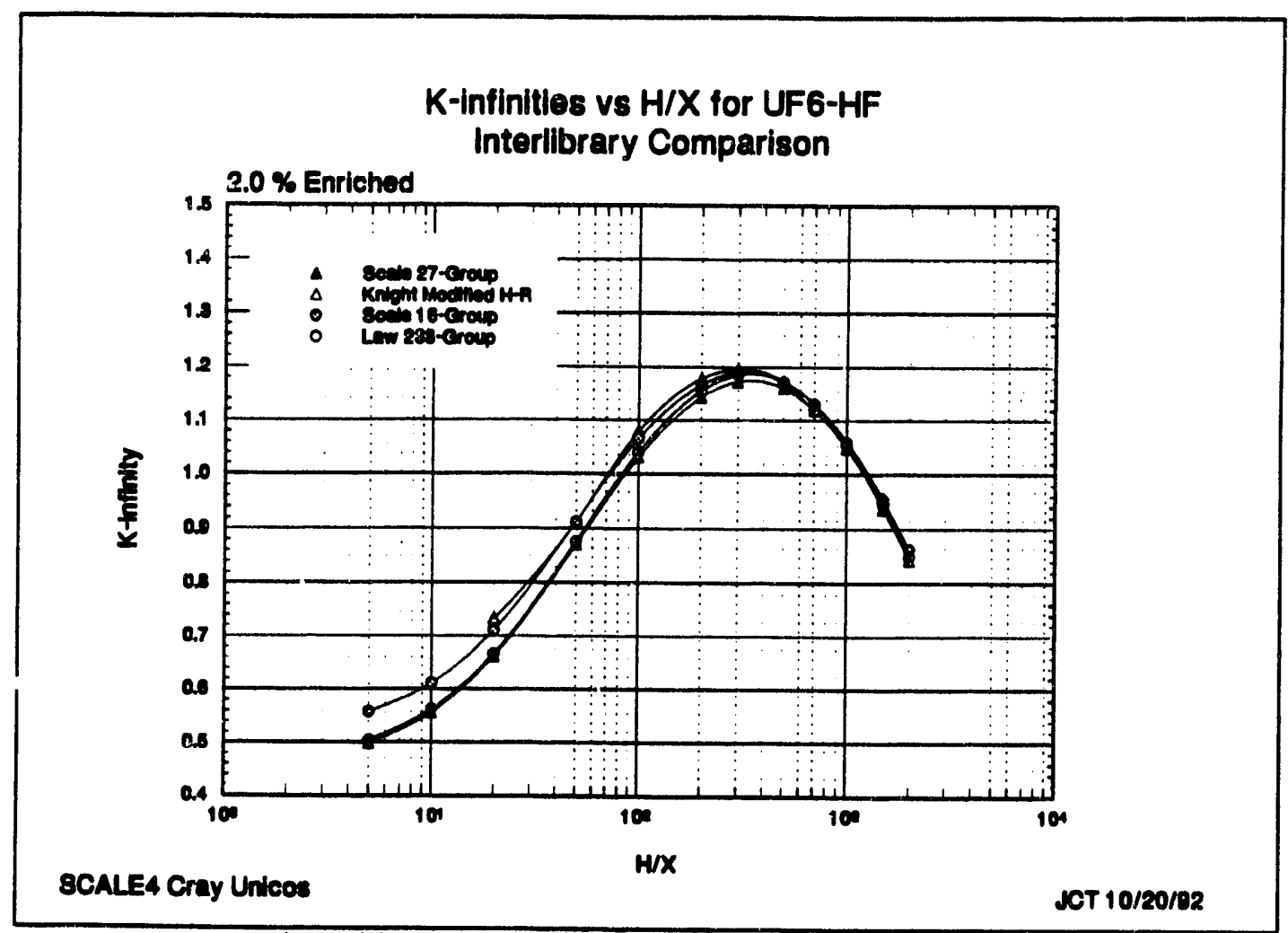

Fig. 20 . $k_{6}$ vs $\mathrm{H} / \mathrm{X}$ for 28 enriched $\mathrm{UF}_{6}-\mathrm{BF}$.

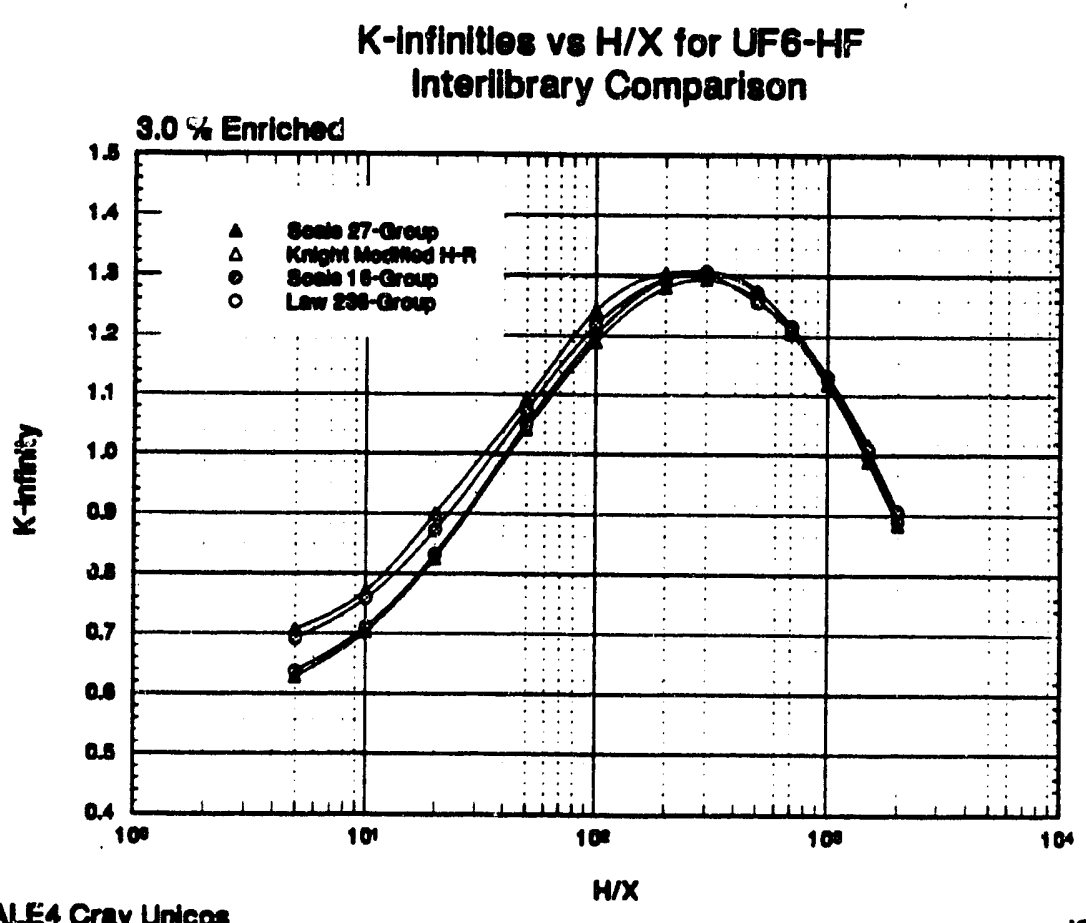

8CAlEA Cray Unicos

JCT 10/20/82

Fig. 21. $k$ v8 $B / X$ for $3^{\text {g enriched }} \mathrm{UF}_{6}-\mathrm{HF}$. 


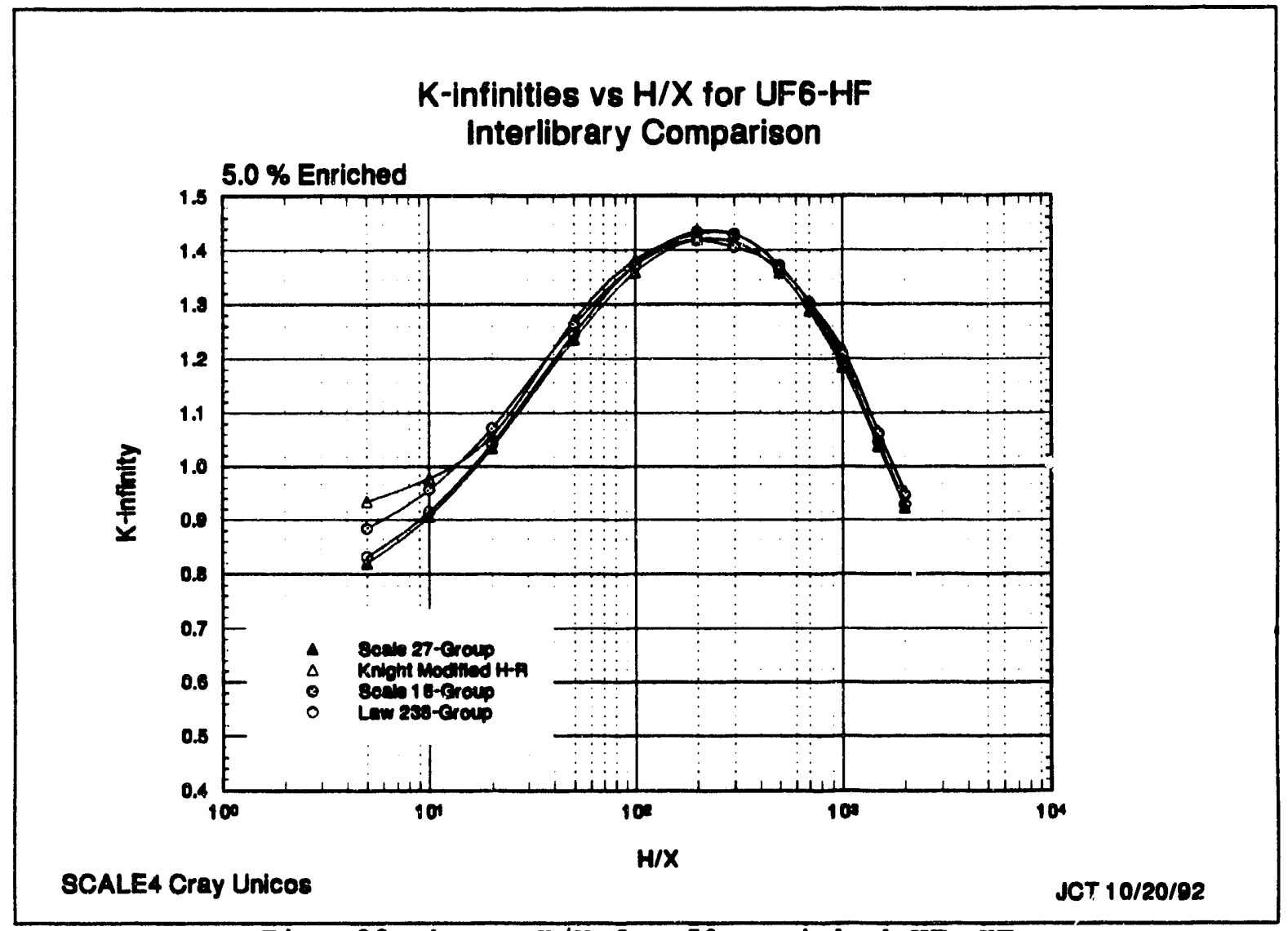

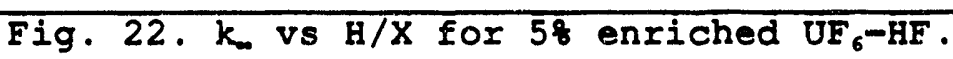


that were made to ${ }^{238} \mathrm{U}$ from ENDF/B-IV to ENDF/B-V. They are also consistent with the fact that the unresolved resonance region for ${ }^{235} U$ and ${ }^{238} U$ were processsed at $\sigma_{p}=50,000$ in the SCALE 27-group library.)

Of interest is the departure between the Knight-modified Hi nsen-Roach calculations and the 27-group calculations as a function of $\mathrm{H} / \mathrm{X}$ and enrichment. There is a significant difference in calculated $\mathrm{k}_{\infty}$ over a range of $\mathrm{H} / \mathrm{X}$ from 5 to 500 at $1.4 \%$ enrichment. The differences at $5 \%$ enrichment do not become significant until the $\mathrm{H} / \mathrm{X}$ ratio is below about 100 . In both cases, the differences in the infinite media multiplication are much greater at the lower values of $k_{\infty}$. The relatively good agreement between the libraries at $\mathrm{H} / \mathrm{X}=500$ for all the systems may help explain why there has not been more evidence in validations of an inadequacy in either library.

In general, minimum-mass systems occur at an $\mathrm{H} / \mathrm{X}$ of around 500 for hydrogenmoderated uranium systems. Most critical experiments designed for low-enriched uranium have been designed to study the moderation region around minimum mass. This is especially true for enrichments much below $5 \%$. The minimum volume system for $5 \%$ enriched uranium occurs at an $\mathrm{H} / \mathrm{X}$ of about 200 . As the enrichment gets smaller, the $\mathrm{H} / \mathrm{X}$ at which minimum volume occurs moves toward an $\mathrm{H} / \mathrm{X}$ of 500 . There are fewer critical experiments with systems of low-enriched uranium at moderation levels below optimum because of the tremendous quantities of uranium required to attain criticality. Of the critical experiments that have been performed at low enrichment, low $\mathrm{H} / \mathrm{X}$, many have utilized "drivers" to attain criticality.

The trends between calculations performed with the Knight-modified Hansen-Roach cross sections, the SCALE 16-group library, and the LAW 238-group library as compared with the SCALE 27-group library are presented graphically in Figs. 23 through 30 . These figures were generated by dividing the calculated $k_{\infty}$ predicted by a library by the $k_{\infty}$ predicted by the SCALE 27-group library. The results are presented on both log scales and linear scales. Figures 23 though 26 show that the 1983 Knight-modified Hansen-Roach (KMHR) calculations have a significant trend that is a function of both the enrichment and $\mathrm{H} / \mathrm{X}$ ratio. The $5 \%$ results range from $0.5 \%$ higher at $\mathrm{H} / \mathrm{X}=300$ to about $9 \%$ higher at $\mathrm{H} / \mathrm{X}=5$ with a minima at $\mathrm{H} / \mathrm{X}=300$. The $1.4 \%$ results range from $1.2 \%$ higher at $\mathrm{H} / \mathrm{X}=2000$ to $8 \%$ higher at $\mathrm{H} / \mathrm{X}=$ 50.

The infinite media ratios for the SCALE 16-group library are shown in Figs. 27 and 28 for the $\mathrm{UO}_{2} \mathrm{~F}_{2}-\mathrm{H}_{2} \mathrm{O}$ system. The SCALE 16-group calculations show the same general trends seen in the 1983 calculations. If the trends observed with both the Knight-modified HansenRoach and SCALE 16-group cross sections compared with the SCALE 27-group rontinue at higher enrichments, then there is a region of enrichments above 5\% where the Hansen-Roach libraries will underpredict $\mathbf{k}_{\infty}$ with respect to the 27 -group library.

Figures 29 and 30 show the ratio of the LAW-238 library against the 27-group library. The calculations using the LAW-238 library range from 0.5 to $1.5 \%$ higher than the 27 -group library over the $\mathrm{H} / \mathrm{X}$ range at all enrichments. 


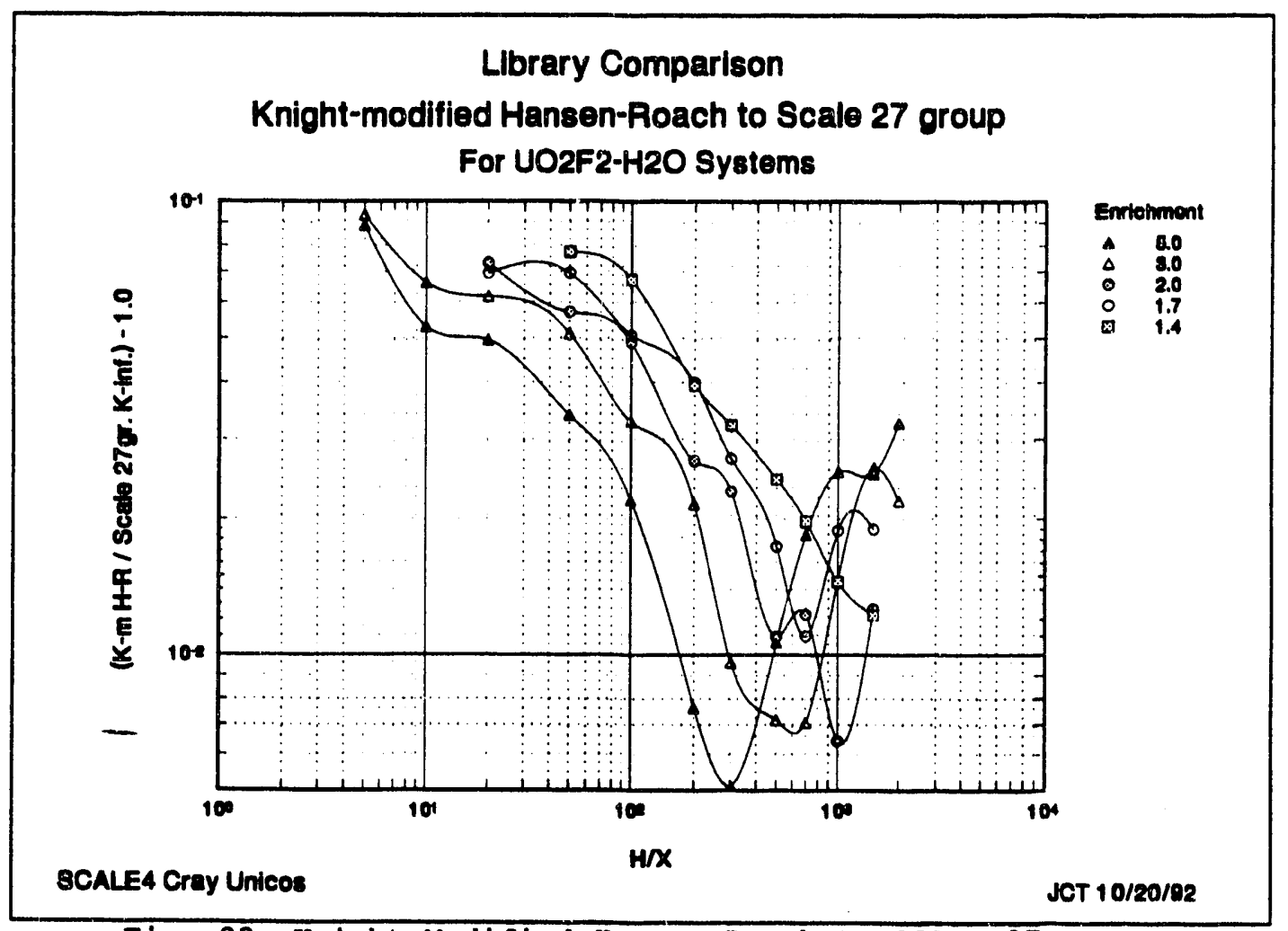

Fig. 23. Knight-Modified Hansen-Roach to SCALE 27-group library comparison - $\mathrm{UO}_{2} \mathrm{~F}_{2}-\mathrm{H}_{2} \mathrm{O}$.

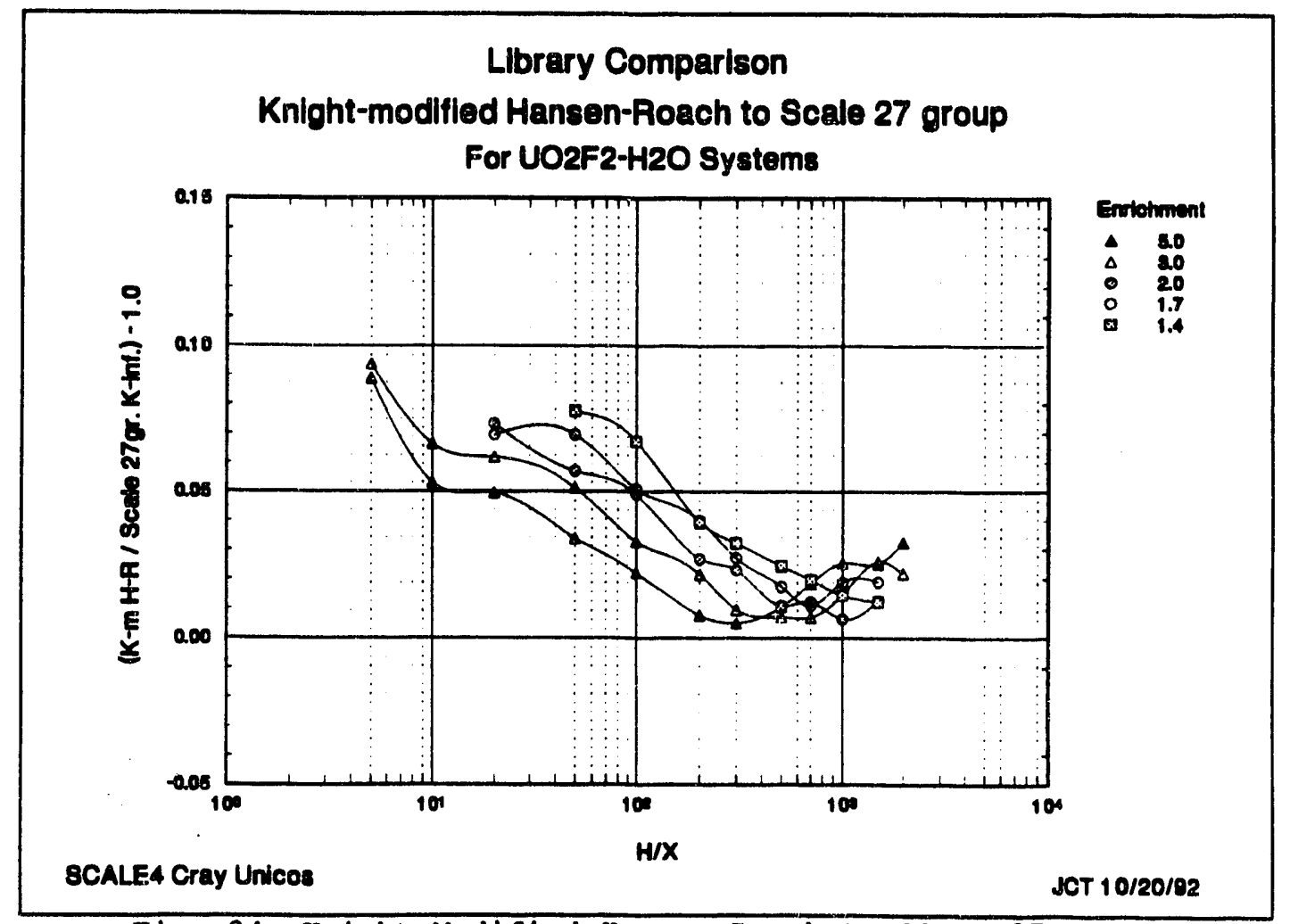

Fig. 24. Knight-Modified Hansen-Roach to SCALE 27-group library comparison - $\mathrm{UO}_{2} \mathrm{~F}_{2}-\mathrm{H}_{2} \mathrm{O}$. 


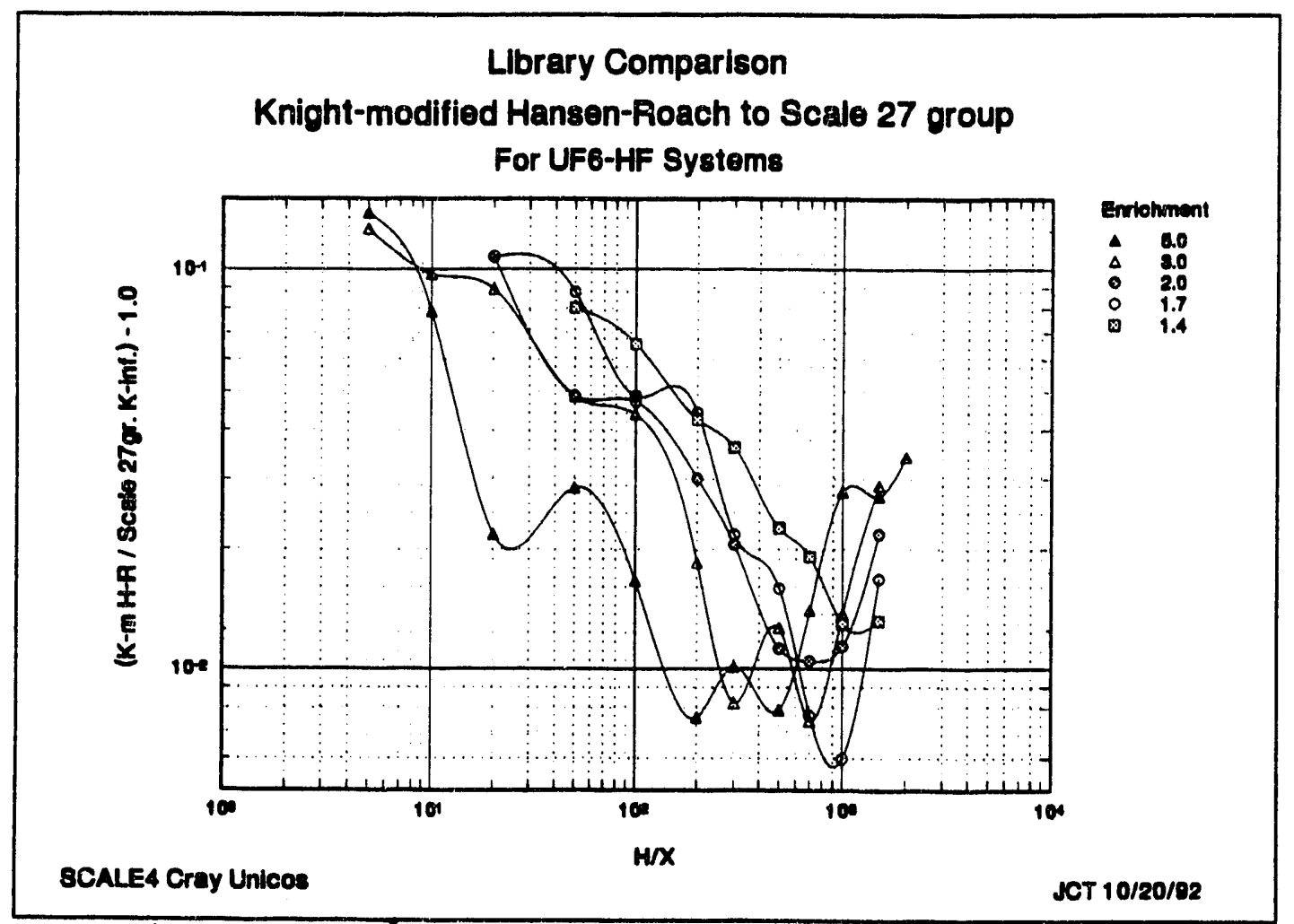

Fig. 25. Knight-Modified Hansen-Roach to SCALE 27-group libxary comparison - $\mathrm{UF}_{6}-\mathrm{HF}$.

Llbrary Comparison

Knight-modifled Hansen-Roach to Scale 27 group

For UF6-HF Systems

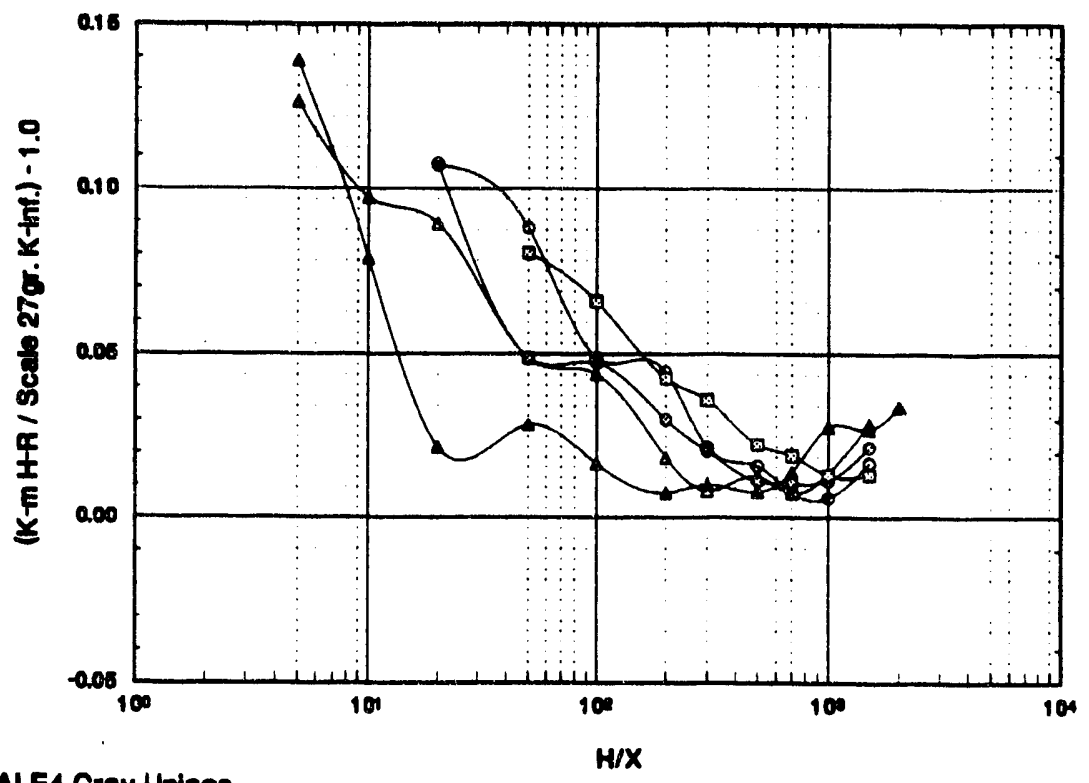

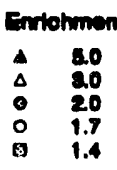

SCALE4 Cray Unicos

JCT 10/20/02

Fig. 26. Knight-Modified Hansen-Roach to SCALE 27-group

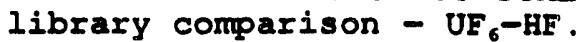




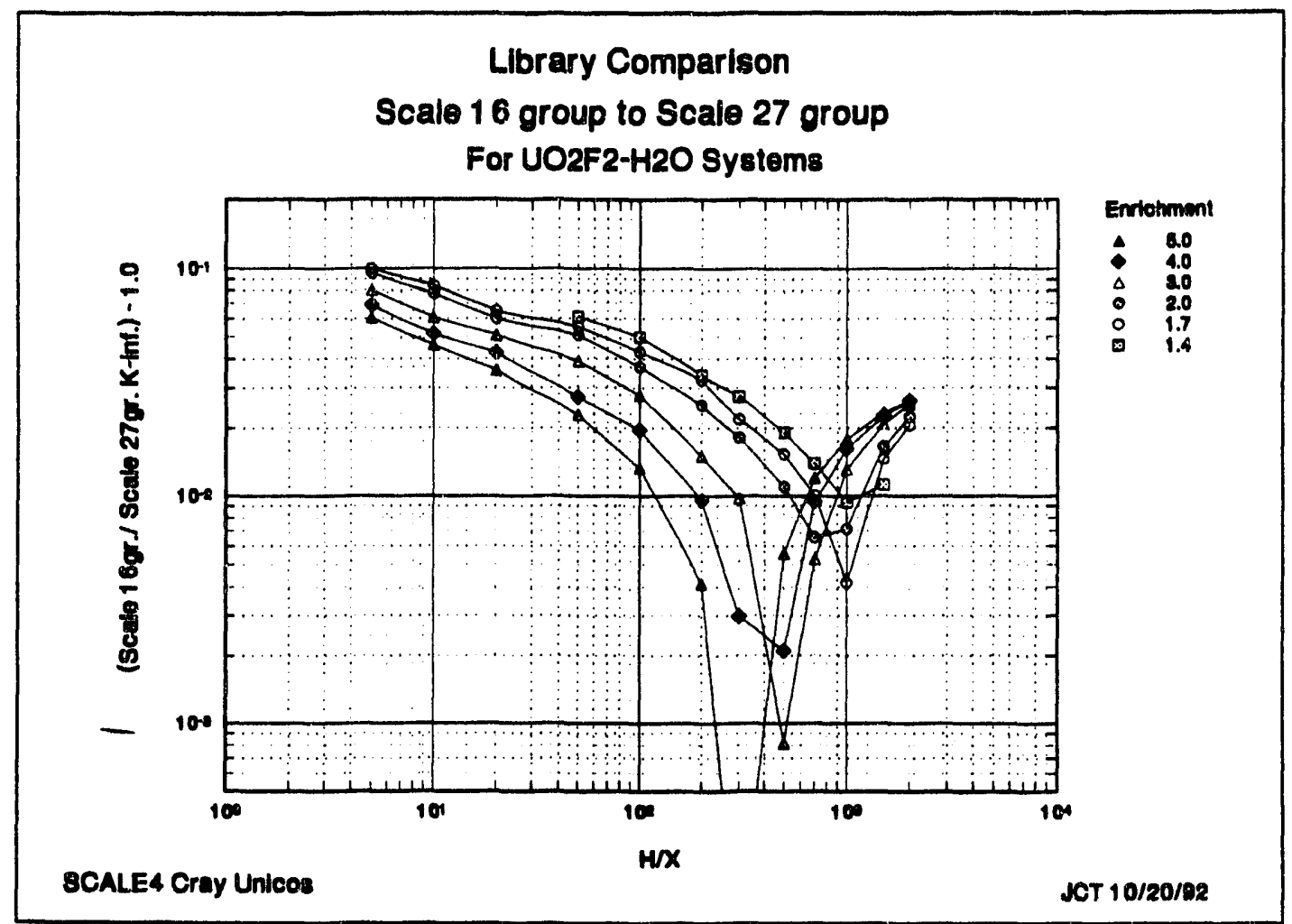

Fig. 27. SCALE 16-group to SCALE 27-group library comparison $-\mathrm{UO}_{2} \mathrm{~F}_{2}-\mathrm{H}_{2} \mathrm{O}$.

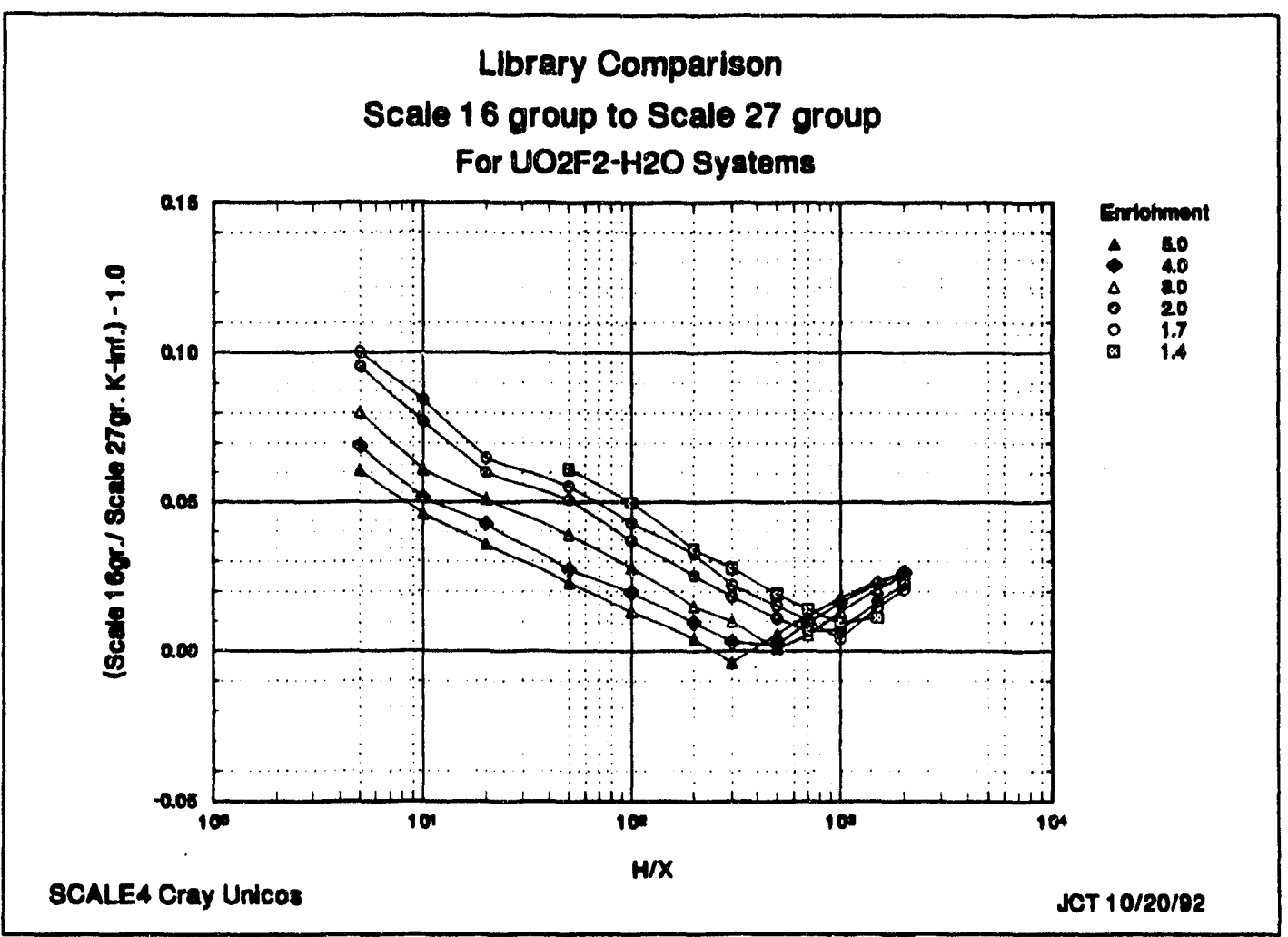

Fig. 28. SCALE 16-group to SCALE 27-group library comparison $-\mathrm{OO}_{2} \mathrm{~F}_{2}-\mathrm{H}_{2} \mathrm{O}$. 


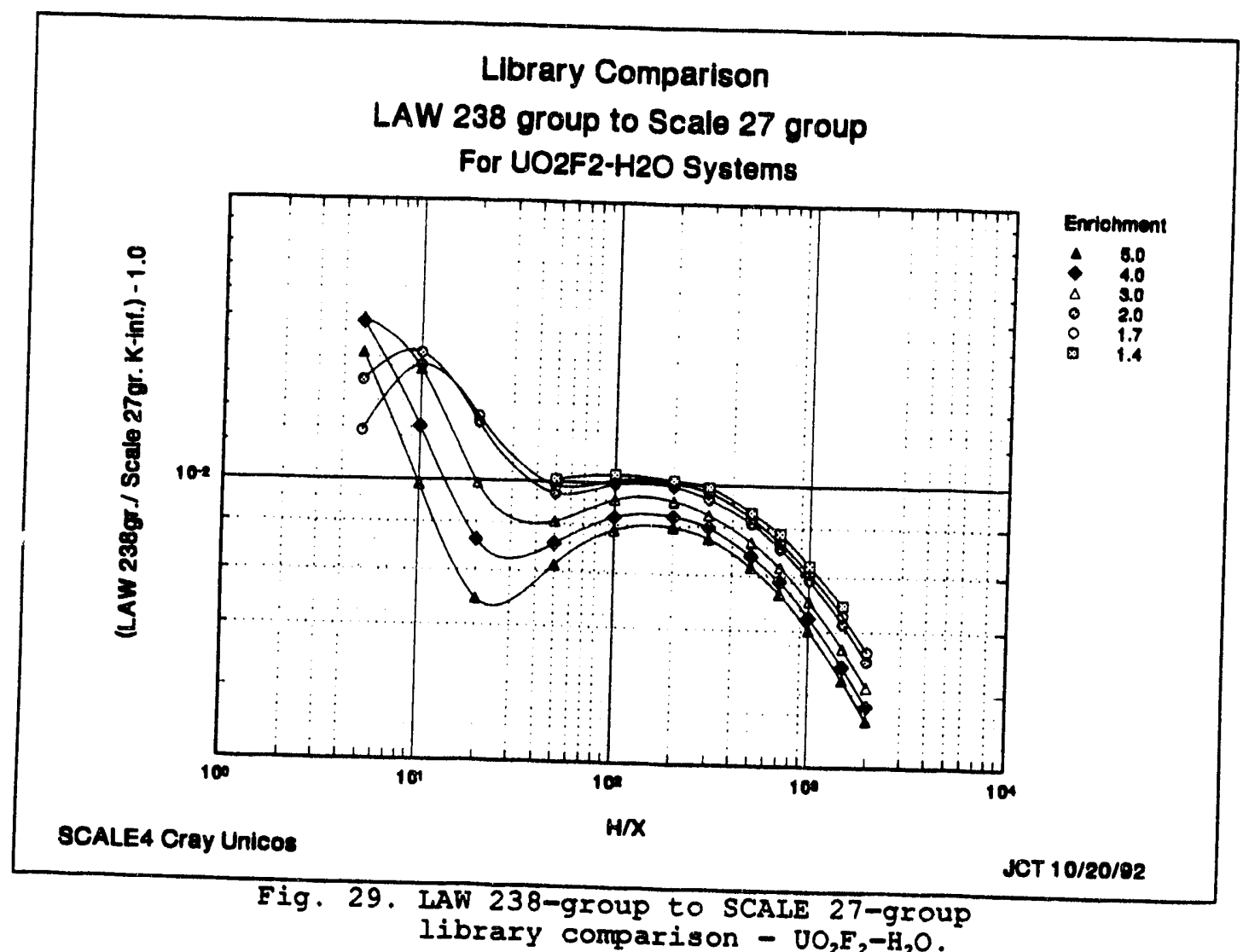

library comparison $-\mathrm{VO}_{2} \mathrm{~F}_{2}-\mathrm{H}_{2} \mathrm{O}$.

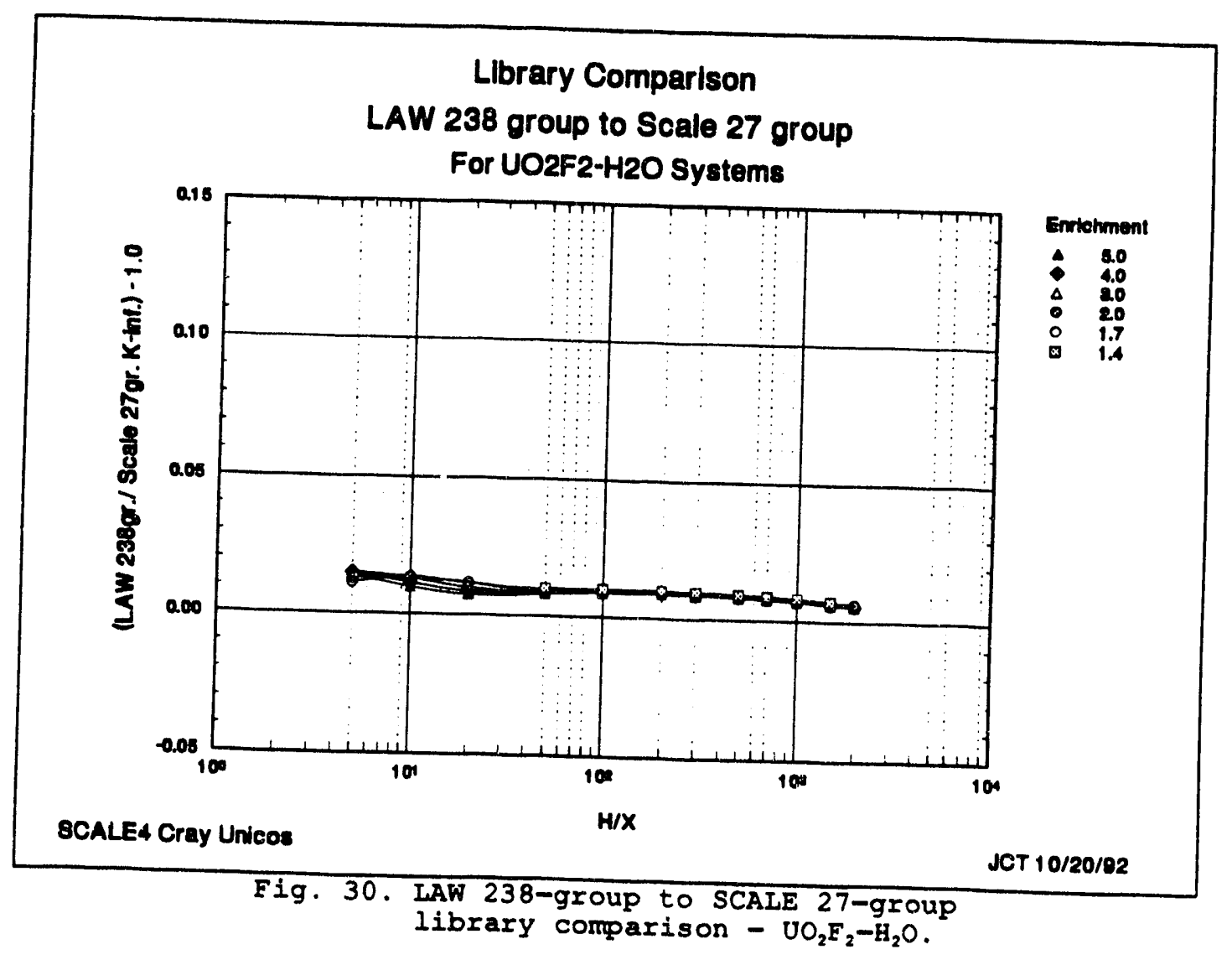


While the interlibrary comparison indicates that there is a difference in the infinite media multiplication factors predicted, it does not demonstrate which library is correct. Additional testing of the adequacy of the ENDF/B libraries was done using the ROLAIDS code.

\subsection{ROLAIDS CALCULATIONS}

The interlibrary comparison did not indicate which cross-section library should be considered more correct for the minimum-mass study. The possibility of poor resonance region cross-section processing could cause poor results for the ENDF/B libraries and exhibit the type of trends observed. The resonance region cross-section processing of the ENDF/B libraries was tested using the ROLAIDS code.

The ROLAIDS code performs a multiregion, energy-pointwise, resolved resonance treatment and was designed for use in cases where the Nordheim treatment implemented in NITAWL may not be adequate. ROLAIDS uses an energy-pointwise library and can more accurately reproduce the flux shape across the resonance region. ROLAIDS also treats resonance overlap. Several of the $1.4 \%$ and $5 \%$ enriched $\mathrm{UO}_{2} \mathrm{~F}_{2}-\mathrm{H}_{2} \mathrm{O}$ calculations were rerun using ROLAIDS-processed cross sections. The results of these calculations are presented in Table 3.

Table 3. ROLAIDS comparison

\begin{tabular}{rrllll}
\hline Enrichment & H/X & $\begin{array}{c}\text { SCALE 27-group } \\
\text { ROLAIDS }\end{array}$ & $\begin{array}{l}\text { ENDF/B-IV } \\
\text { NITAWL }\end{array}$ & $\begin{array}{c}\text { LAW 238-group } \\
\text { ROLAIDS }\end{array}$ & $\begin{array}{l}\text { ENDF/B-V } \\
\text { NITAWL }\end{array}$ \\
\hline 5.0 & 5 & 0.866579 & 0.881333 & 0.889335 & 0.893399 \\
& 10 & 0.946088 & 0.963163 & 0.969576 & 0.972681 \\
& 200 & 1.43972 & 1.44607 & 1.45673 & 1.45904 \\
& 2000 & 0.942285 & 0.943632 & 0.948294 & 0.948921 \\
& & & & & \\
1.4 & 5 & 0.45088 & 0.462036 & 0.463756 & 0.466234 \\
& 100 & 0.907377 & 0.920974 & 0.929367 & 0.930380 \\
& & & & & \\
\hline
\end{tabular}

The results in Table 3 indicate that ROLAIDS consistently underpredicts NITAWL for the ENDF/B-IV calculations. This result is in the opposite direction of that required to explain the difference between the 27-group and Hansen-Roach calculations. The difference between ROLAIDS and NITAWL results for the ENDF/B-IV cross sections has been observed in the past. $^{23}$ 
There appears to be good agreement between the ENDF/B-V ROLAIDS and NITAWL calculations. The ENDF/B-V results are 0.5 to $1 \%$ greater than the ENDF/B-IV NITAWL results, which is the general trend expected from ENDF/B-IV to ENDF/B-V. The inconsistency of the ENDF/B-IV ROLAIDS calculations raises questions about the reliability of those results. The ENDF/B-V results indicate that there is probably not a problem in the NITAWL resonanceregion cross sections for these systems.

The ROLAIDS results did not demorstrate a significant inadequacy of the 27-group calculations. Critical experimental data were reviewed to determine if there were experiments that would test the regions of the cross sections where the largest differences occurred. The Physical Constants Test Reactor (PCTR) series of experiments was identified as a possible candidate.

\subsection{THE PCTR ANALYSIS}

The PCTR experiments are a series of experiments which were performed at Hanford Experimental Development Laboratory (HEDL) in the 1950s and early 1960s. A series of experiments performed in 1957 for $\mathrm{UO}_{2}-\mathrm{H}_{2} \mathrm{O}$ mixtures at enrichments near $1 \%$ was of particular interest because it included $k_{\infty}$ measurements for systems with an infinite media multiplication factor of less than 1.0. The trends in the Hansen-Roach and the 27-group calculations indicate that the lower the enrichment, the larger the disagreement in calculated $k_{\infty}$. Table 4 gives the experimentally measured values for $k_{\infty}$ along with those calculated using the 27-group and Hansen-Roach libraries. Selected cases were analyzed with ROLAIDS and the LAW 238-group library. Both the Hansen-Roach $\mathrm{dE} / \mathrm{E}$ and $\mathrm{X}(\mathrm{E})$ hydrogen were used to determine if the highenergy scattering was impacting these results.

The results presented in Table 4 lead to the following observations:

1. The SCALE 27-group ENDF/B-IV library gives consistently better results when compared with the results using the Knight-modified Hansen-Roach cross sections. The ratio of the results of the Knight-modified Hansen-Roach calculations to the SCALE 27. group library calculations follow the same general trends as those observed in Fig. 23.

2. The 27-group calculations appear to be consistently 0.5 to $1 \%$ low relative to the experimental values.

3. The ENDF/B-IV results using ROLAIDS tend to underpredict both the measured $\mathbf{k}_{\infty}$ and that calculated with the SCALE 27-group library using NITAWL.

4. The LAW-238 ENDF/B-V library appears to give good overall agreement for the few cases in which this library was used. 


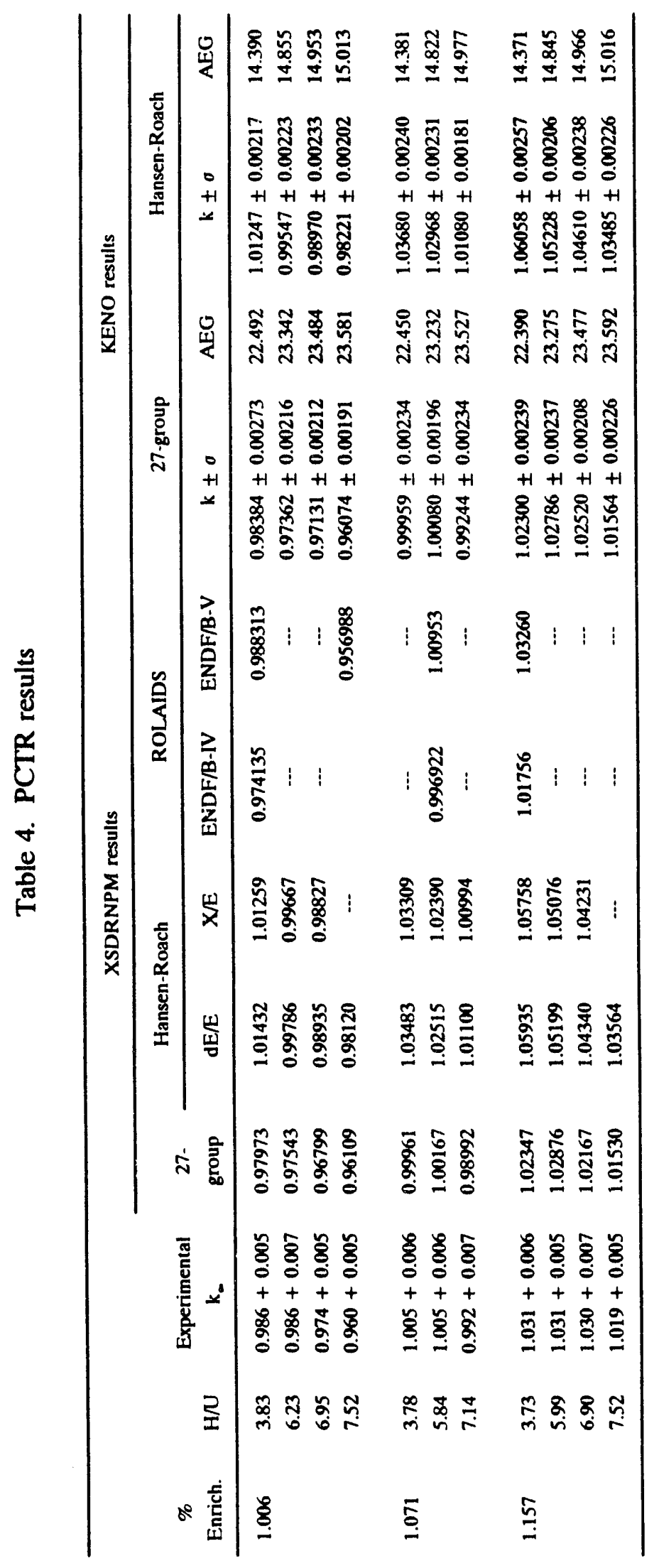


The case for $1.006 \%$ enrichment at $\mathrm{H} / \mathrm{U}=3.83$ was selected for further study to determine the cause of the poor performance of the Knight-modified Hansen-Roach cross sections. The SCALE 16-group library is based on the Knight-modified cross sections which have been put into a form that can be processed by BONAMI. BONAMI performs an iteration and calculates the $\sigma_{\mathrm{p}}$ on a groupwise basis as opposed to selecting a specific $\sigma_{\mathrm{p}}$ cross-section set. To test if there is a sensitivity to the manner in which $\sigma_{\mathrm{p}}$ 's are calculated, the $\sigma_{\mathrm{p}}$ 's for ${ }^{235} \mathrm{U}$ and ${ }^{238} \mathrm{U}$ were calculated by the KENO-IV methodology. The results using the Knight-modified Hansen-Roach cross sections gave $k_{\infty}$ values within a few tenths of a percent of the SCALE 16group library.

All the Hansen-Roach calculations considered up to this point have been ORNL Knightmodified versions of the cross sections. It was of interest to determine if the poor performance of the Hansen-Roach calculations could be attributed to the Knight modifications. Several calculations were performed using the original Hansen-Roach cross-section library. The $\sigma_{\mathrm{p}}$ methodology proposed by Hopper-Renier of $\xi$ weighting was used, ${ }^{24}$ with one modification. The modification involves adding into the $\sigma_{\mathrm{p}}$ calculation the background self-shielding for the nuclide being considered. The original Hansen-Roach library using this $\sigma_{p}$ formalism gave a value of $k_{\infty}$ $=0.99317$ and is in relatively good agreement with experiment. This represents a $2 \%$ improvement. The significant improvement of the calculated $\mathbf{k}_{\infty}$ value suggests that there is an inadequacy in the manner in which the Knight modifications were applied to the original Hansen-Roach cross sections. The systems considered in the minimum-mass study may have extended into the range of extrapolation of the Knight modifications, and the results of the analysis with the Knight-modified Hansen-Roach cross sections may be significantly biased.

Additional comparisons using the modified Hopper-Renier $\sigma_{\mathrm{p}}$ weighting were performed for the $5 \%$ enriched $\mathrm{UO}_{2} \mathrm{~F}_{2}-\mathrm{H}_{2} \mathrm{O}$ system at $\mathrm{H} / \mathrm{X}=5$. The use of this formulation with the original Hansen-Roach library improved the agreement to the SCALE 27-group library but did not account for all of the difference. A series of calculations were performed in which the cross sections in the original Hansen-Roach library were replaced by ENDF/B-V cross sections processed into the same group structure. The results of these replacement calculations are presented in Table 5.

As shown in Table 5, the use of the Hopper-Renier formulation and the original HansenRoach library (Case $01 \mathrm{~A}$ ) yields a $0.7 \%$ reduction in the infinite media multiplication factor compared to the SCALE-4 16-group library. The replacement of the Hansen-Roach fluorine in Case $01 \mathrm{~A}$ yields a $1 \%$ reduction in infinite media multiplication, and the replacement of oxygen yields an $0.8 \%$ reduction. Replacement of the Hansen-Roach hydrogen with ENDF/B-V hydrogen yields a slight increase in $k_{\infty}$. Replacement of $\mathrm{H}, \mathrm{O}$, and $\mathrm{F}$ in Case $01 \mathrm{~A}$ with ENDF/B-V cross sections yields a $1.5 \%$ reduction in the calculated $k_{\infty}$.

It appears that the Knight-modified Hansen-Roach cross sections are not well suited for the range of systems encountered in the minimum-mass study. Both the Knight-modified and original Hansen-Roach libraries tend to overpredict the infinite media multiplication factor and thus underpredict the critical radii. This is a reverse in trend compared with the observations of 
Table 5. H-R replacement calculations for $\mathrm{U}(5) \mathrm{O}_{2} \mathrm{~F}_{2}$ and water at $\mathrm{H} / \mathrm{X}=5$

\begin{tabular}{lll}
\hline Case & \multicolumn{1}{c}{ Description } & $\mathbf{k}_{\infty}$ \\
\hline Ref. & SCALE-4 16-group & 0.934757 \\
01A & Original H-R library & 0.928203 \\
01B & Case 01A except ENDF/B-V F & 0.918825 \\
01C & Case 01A except ENDF/B-V O & 0.921045 \\
01D & Case 01A except ENDF/B-V H & 0.931194 \\
01E & Case 01A except ENDF/B-V F \& O & 0.911973 \\
01F & Case 01A except ENDF/B-V F,O \& H & 0.914886 \\
\hline
\end{tabular}

Stratton. $^{25}$ The reversal of calculational trends for the original library may be due to the use of different $\sigma_{\mathrm{p}}$ formulations.

It also appears that one might expect a 0.5 to $1 \%$ negative bias in the value of $\mathbf{k}_{\infty}$ predicted by the SCALE 27-group ENDF/B-IV NITAWL-processed cross-section library for the range of systems analyzed. This bias may be accounted for using the procedures outlined in Sect. 2. The ROLAIDS-processed ENDF/B-IV cross sections tend to underpredict the NITAWL-processed library and significantly underpredict the measured $k_{\infty}$ 's in the PCTR experiments analyzed.

The LAW 238-group ENDF/B-V library gave good results for the PCTR calculations and appears to be the most reliable of the libraries tested.

An important conclusion of the investigation into the discrepancies between calculations with the Knight-modified Hansen-Roach cross sections and the SCALE 27-group library is that there are areas of application that have not been validated. Infinite media measurements and critical experiments at the lower range of moderation level may need to be included in future validations. If these experiments are not available, then new critical experiments are needed.

It is apparent that the $\sigma_{\mathrm{p}}$ formalism used with the Hansen-Roach library must be consistent between the validation and the subsequent application. The trends and bias observed will be related to this formalism. This statement can be generalized. In validation of a criticality code, the code, cross sections, and cross-section processing methodology are being validated. In application, care must be taken to ensure that the code, cross sections, and processing methodology are consistent with the validation. If the application is inconsistent with the validation, trends and bias may be introduced which have not been properly taken into account in establishing the calculational acceptance criteria. 


\section{EFFECTS OF MODERATION LEVEL ON THE NEUTRON SPECTRUM}

The significant disagreement between the calculations using the SCALE 27-group and Knight-modified Hansen-Roach libraries was not expected. Both of these libraries have been in use for years and have been validated against substantially the same set of critical experiments. Large differences between the two libraries have not been previously encountered. The large differences between the libraries seen in the minimum-mass study suggest that the libraries are being used outside of their respective validation. The purpose of this section is to briefly review the adequacy of the parameters used to demonstrate the area of applicability and range of applicability of a particular set of validation problems in relation to another (unknown) system.

In the strictest sense, one should have critical experiments (benchmarks) that are directly related to the unknown systems being calculated. The adequacy of the codes and cross sections for use in predicting criticality for the unknown system should be demonstrated ty calculating the benchmarks (this is commonly called the "validation" of the code ard cross sections). Virtually all the critical experiments used for benchmarking codes were performed decades ago. In practice, the criticality engineer must review the data base of old experimerts and find those directly applicable to the systems under consideration. In the absence of directly applicable experiments, those that appear to encompass the unknown system parameters must be used for validation, since there is little chance of obtaining new experiments in a timely manner.

Common parameters in establishing the range of applicability of a validation include the fissile material compound, the uranium enrichment, the moderator compound, the level of moderation, and the system geometry and reflective conditions. Another parameter which has been used is the average energy group of the neutron-causing fission (AEG). ${ }^{26,27,28}$

The systems considered in the minimum-mass study have low-enriched uranium in the form of $\mathrm{UO}_{2} \mathrm{~F}_{2}$ or $\mathrm{UF}_{6}$ as the uranium compound. The moderators considered are $\mathrm{H}_{2} \mathrm{O}$ and $\mathrm{HF}$ over a range of moderation levels. Fully $\mathrm{H}_{2} \mathrm{O}$-reflected spherical geometry was considered. The fissile materials, moderators, moderation levels, and geometries are those one might expect to encounter (routinely) in a gaseous diffusion plant or in the analysis of $\mathrm{UF}_{6}$ transportation and storage.

There are a number of critical experiments for low-enriched uranium. These cover an enrichment range from near 1 to $5 \%$. A number of these experiments involve $\mathrm{UO}_{2} \mathrm{~F}_{2}$ as the fissile compound. There are no critical experiments that involve low-enriched $U_{6}$. Experiments with $\mathrm{UF}_{4}$ are generally used to validate cross sections for $\mathrm{UF}_{6}$ systems.

The moderation levels for the critical experiments for $\mathrm{H}_{2} \mathrm{O}$-moderated $\mathrm{UO}_{2} \mathrm{~F}_{2}$ cover a range from $H / U=15$ to $H / U=100$. At moderator ratios much below $H / U=15$, the system is no longer a "free-flowing" solution, but more like syrup; at moderation ratios below $\mathrm{H} / \mathrm{U}=$ 9 , the systems become more comparable to toothpaste; below $\mathrm{H} / \mathrm{U}=4$, one has mixtures of solid hydrated uranyl fluoride compounds. Critical experiments with other materials, such as $\mathrm{UF}_{4}$ or uranium oxides, are used to evaluate the cross sections at the lower moderation levels. There 
are a number of experiments involving these compounds with paraffin, sterotex, or water as the moderator. There are no low-enriched critical experiments that have $\mathrm{HF}$ as a moderator.

The lack of experiments with liquid HF may be of significant importance. There are no thermal-scattering data in ENDF for HF. The cross sections used for hydrogen in calculations involving HF are those for water-bound hydrogen. There is no reason to expect that the neutron thermal scattering in water and HF are the same. The only way to evaluate the acceptability of this approximation is through evaluation of the thermal-scattering kernel in $\mathrm{HF}$ and through experimentation with HF as a moderator.

In establishing an acceptable set of validation experiments for the calculations performed in Sect. 2, observe that there are few critical experiments performed in spherical geometry for low-enriched uranium. This is because of the difficulties involved in manufacturing the spherical vessels in combination with the appropriate size for criticality. It is rare that a partially filled spherical experiment is described because the calculational codes available twenty years ago could not handle these systems. Slab, cylindrical, and spherical geometries must be considered collectively in order to establish an adequate benchmark data base.

The AEG has been used as a parameter to establish the range of applicability of validations. The AEG has embedded information related to the moderation level and leakage of a system. It also has embedded information on the spectral effects of the reflector. Using the AEG as a parameter tends to smear all of the critical experiments involving different geometries, fissile compounds, moderators, and moderation levels into the same group. The unknown system can be related through its AEG to the group of validation experiments.

The AEG for several of the infinite media systems in the minimum moderator mass study were calculated using KENO V.a. The systems considered were $\mathrm{UO}_{2} \mathrm{~F}_{2}-\mathrm{H}_{2} \mathrm{O}$ at $5 \%$ enrichment, $\mathrm{UO}_{2} \mathrm{~F}_{2}-\mathrm{H}_{2} \mathrm{O}$ at $1.4 \%$ enrichment, and $\mathrm{UF}_{6}-\mathrm{HF}$ at $5 \%$ enrichment. The results are presented in Table 6, along with XSDRNPM results. There is excellent agreement between KENO V.a and XSDRNPM for both of the cross-section libraries considered.

Additional details of the neutron spectrum for the SCALE 27-group calculations in Table 6 were obtained from the system summary tables of the XSDRNPM calculations and are presented in Tables 7 through 9. Included in these tables is the percentage of the flux, absorptions, and fissions for five energy regions. This enables one to determine what the important cross-section regions are for the problem. The energy region boundaries were chosen to correspond roughly to the following energy regions: (1) fission spectrum (groups 1-7 of the 27-group library); (2) unresolved resonance region (groups 8 and 9); (3) top of the ${ }^{238} U$ resolved resonance region (groups 10-12); (4) the ${ }^{235} \mathrm{U}$ resolved resonance region and the bottom of the ${ }^{238} \mathrm{U}$ resolved resonance region (groups 13-15); and (5) the thermal region (groups 16-27). The percentage of the generating flux which occurs in each of the five energy regions is also given in Table 7. 
Table 6. Intercomparison of XSDRNPM and KENO V.a results

\begin{tabular}{|c|c|c|c|c|c|c|c|c|}
\hline \multirow[b]{3}{*}{$\mathrm{H} / \mathrm{X}$} & \multicolumn{7}{|c|}{$5 \%$ enriched $\mathrm{UO}_{2} \mathrm{~F}_{2}-\mathrm{H}_{2} \mathrm{O}$} & \\
\hline & \multicolumn{4}{|c|}{ 27-Group } & \multicolumn{4}{|c|}{ Hansen-Roach } \\
\hline & $\begin{array}{l}\text { XSDRN } \\
k_{\infty}\end{array}$ & $\begin{array}{c}\text { KENO V.a } \\
k\end{array}$ & Dev. & AEG & $\begin{array}{c}\text { XSDRN } \\
k_{\infty}\end{array}$ & $\begin{array}{c}\text { KENO V.a } \\
\mathbf{k}\end{array}$ & Dev. & AEG \\
\hline 5 & 0.881333 & 0.88112 & 0.00209 & 10.0848 & 0.934757 & 0.93707 & 0.00249 & 7.6242 \\
\hline 10 & 0.963163 & 0.96512 & 0.00253 & 12.2513 & 1.00741 & 1.00759 & 0.00239 & 9.0192 \\
\hline 20 & 1.08401 & 1.08783 & 0.00279 & 15.3618 & 1.12277 & 1.11931 & 0.00332 & 10.8151 \\
\hline 50 & 1.27189 & 1.26804 & 0.00319 & 19.3531 & 1.30100 & 1.30207 & 0.00290 & 13.0341 \\
\hline 100 & 1.38902 & 1.39477 & 0.00356 & 21.7170 & 1.40743 & 1.40793 & 0.00321 & 14.2131 \\
\hline 200 & 1.44607 & 1.44711 & 0.00296 & 23.2340 & 1.45203 & 1.45073 & 0.00287 & 14.9778 \\
\hline 500 & 1.38267 & 1.38230 & 0.00291 & 24.3418 & 1.39039 & 1.39216 & 0.00281 & 15.5130 \\
\hline 1500 & 1.06147 & 1.06229 & 0.00186 & 24.8981 & 1.08629 & 1.08505 & 0.00187 & 15.7762 \\
\hline \multicolumn{9}{|c|}{$1.4 \%$ enriched $\mathrm{UO}_{2} \mathrm{~F}_{2}-\mathrm{H}_{2} \mathrm{O}$} \\
\hline 100 & 0.920974 & 0.91856 & 0.00262 & 19.6329 & 0.966783 & 0.96463 & 0.60262 & 12.9369 \\
\hline 200 & 1.04172 & 1.04320 & 0.00288 & 21.8093 & 1.07727 & 1.07574 & 0.00302 & 14.0912 \\
\hline 500 & 1.08382 & 1.08377 & 0.00208 & 23.5369 & 1.10453 & $1.1 C 765$ & 0.002222 & 15.0118 \\
\hline 1500 & 0.903401 & 0.90499 & 0.00171 & 24.4997 & 0.913548 & 0.91644 & $0.00^{1} 53$ & 15.531 .6 \\
\hline \multicolumn{9}{|c|}{$5 \%$ enricher $\mathrm{UF}_{6}-\mathrm{HF}$} \\
\hline 10 & 0.905968 & 0.90803 & 0.00267 & 12.8951 & 0.955991 & 0.95210 & 0.00245 & 9.4568 \\
\hline 50 & 1.23487 & 1.23205 & 0.00323 & 19.7314 & 1.26124 & 1.25983 & 0.00305 & 13.2370 \\
\hline 200 & 1.41973 & 1.42274 & 0.00293 & 23.3646 & 1.41898 & 1.41686 & 0.00285 & 15.0473 \\
\hline
\end{tabular}


Table 7. Selected spectral information for $\mathrm{U}(5) \mathrm{O}_{2} \mathrm{~F}_{2}-\mathrm{H}_{2} \mathrm{O}$ systems

\begin{tabular}{|c|c|c|c|c|c|c|c|}
\hline $\mathrm{H} / \mathrm{X}$ & $\mathrm{H} / \mathrm{U}$ & Group & $\begin{array}{c}\text { Flux } \\
\%\end{array}$ & $\begin{array}{c}\text { Absorptions } \\
\% \\
\end{array}$ & $\begin{array}{c}\text { Fissions } \\
\%\end{array}$ & AEG & $\begin{array}{c}\text { Generating } \\
\text { flux }\end{array}$ \\
\hline 5 & 0.25 & $\begin{array}{c}<7 \\
8-9 \\
10-12 \\
13-15 \\
(>16)\end{array}$ & $\begin{array}{r}45.82 \\
33.62 \\
17.72 \\
2.10 \\
0.74\end{array}$ & $\begin{array}{r}15.28 \\
25.07 \\
43.31 \\
11.39 \\
4.95\end{array}$ & $\begin{array}{r}22.39 \\
13.35 \\
40.47 \\
9.69 \\
14.10\end{array}$ & 10.08 & $\begin{array}{r}44.5 \\
11.9 \\
13.2 \\
8.1 \\
22.3\end{array}$ \\
\hline 10 & 0.51 & $\begin{array}{c}<7 \\
8-9 \\
10-12 \\
13-15 \\
(>16)\end{array}$ & $\begin{array}{r}47.45 \\
28.16 \\
18.75 \\
3.71 \\
1.93\end{array}$ & $\begin{array}{l}13.14 \\
16.94 \\
40.47 \\
16.78 \\
12.67\end{array}$ & $\begin{array}{r}20.85 \\
8.18 \\
33.66 \\
12.46 \\
24.85\end{array}$ & 12.25 & \\
\hline 20 & 1.01 & $\begin{array}{c}<7 \\
8-9 \\
10-12 \\
13-15 \\
(>16)\end{array}$ & $\begin{array}{r}48.61 \\
23.17 \\
18.62 \\
5.43 \\
4.17\end{array}$ & $\begin{array}{l}10.49 \\
10.38 \\
33.33 \\
19.93 \\
25.87\end{array}$ & $\begin{array}{r}15.17 \\
4.40 \\
23.29 \\
12.11 \\
45.03\end{array}$ & 15.36 & \\
\hline 50 & 2.53 & $\begin{array}{c}<7 \\
8-9 \\
10-12 \\
13-15 \\
(>16)\end{array}$ & $\begin{array}{r}48.73 \\
18.15 \\
17.16 \\
6.95 \\
9.01\end{array}$ & $\begin{array}{r}6.84 \\
4.89 \\
21.94 \\
18.69 \\
47.64\end{array}$ & $\begin{array}{r}8.63 \\
1.74 \\
11.53 \\
8.20 \\
69.90\end{array}$ & 19.35 & \\
\hline 100 & 5.06 & $\begin{array}{c}<7 \\
8-9 \\
10-12 \\
13-15 \\
(>16)\end{array}$ & $\begin{array}{r}47.20 \\
15.40 \\
15.63 \\
7.35 \\
14.42\end{array}$ & $\begin{array}{r}4.50 \\
2.63 \\
14.81 \\
15.30 \\
62.76\end{array}$ & $\begin{array}{r}5.17 \\
0.85 \\
6.23 \\
5.1 \% \\
82.58\end{array}$ & 21.72 & \\
\hline 200 & 10.1 & $\begin{array}{c}<7 \\
8-9 \\
10-12 \\
13-15 \\
(>16)\end{array}$ & $\begin{array}{r}43.86 \\
13.11 \\
13.90 \\
7.18 \\
22.95\end{array}$ & $\begin{array}{r}2.78 \\
1.38 \\
9.67 \\
11.68 \\
74.49\end{array}$ & $\begin{array}{r}2.96 \\
0.42 \\
3.31 \\
3.05 \\
90.26\end{array}$ & 23.23 & \\
\hline 500 & 15.2 & $\begin{array}{c}<7 \\
8-9 \\
10-12 \\
13-15 \\
(>16)\end{array}$ & $\begin{array}{r}36.68 \\
10.29 \\
11.26 \\
6.25 \\
35.52\end{array}$ & $\begin{array}{r}1.43 \\
0.58 \\
5.37 \\
7.81 \\
84.81\end{array}$ & $\begin{array}{r}1.41 \\
0.18 \\
1.49 \\
1.49 \\
95.43\end{array}$ & 24.34 & \\
\hline 500 & 50.6 & $\begin{array}{c}<7 \\
8-9 \\
10-12 \\
13-15 \\
(>16)\end{array}$ & $\begin{array}{r}26.84 \\
7.29 \\
8.13 \\
4.73 \\
53.01\end{array}$ & $\begin{array}{r}0.71 \\
0.20 \\
2.62 \\
4.69 \\
91.78\end{array}$ & $\begin{array}{r}0.65 \\
0.08 \\
0.67 \\
0.71 \\
97.89\end{array}$ & 24.89 & \\
\hline
\end{tabular}


36

Table 8. Selected spectral information for $\mathrm{U}(1.4) \mathrm{O}_{2} \mathrm{~F}_{2}-\mathrm{H}_{2} \mathrm{O}$ systems

\begin{tabular}{ccccccc}
\hline \multirow{H}{*}{$/ \mathrm{X}$} & $\mathrm{H} / \mathrm{U}$ & Group & $\begin{array}{c}\text { Flux } \\
\%\end{array}$ & $\begin{array}{c}\text { Absorptions } \\
\%\end{array}$ & $\begin{array}{c}\text { Fissions } \\
\%\end{array}$ & AEG \\
\hline 100 & 0.08 & $<7$ & 43.78 & 8.12 & 13.11 & 19.63 \\
& & $8-9$ & 19.18 & 6.90 & 1.14 & \\
& & $10-12$ & 17.76 & 22.92 & 7.49 & \\
& & $13-15$ & 7.01 & 18.56 & 5.52 & \\
& & $(>16)$ & 12.27 & 43.50 & 72.74 & \\
500 & 7.09 & $<7$ & 37.45 & 3.27 & 4.53 & 23.54 \\
& & $8-9$ & 11.68 & 1.65 & 0.22 & \\
& & $10-12$ & 12.35 & 9.69 & 1.76 & \\
& & $13-15$ & 6.39 & 11.56 & 1.66 & \\
& & $(>16)$ & 32.13 & 73.83 & 91.83 & \\
1500 & 21.3 & & & & & \\
& & & & & & \\
& & $8-9$ & 28.40 & 1.51 & 2.22 & 24.49 \\
& & $10-12$ & 8.03 & 0.58 & 0.09 & \\
& & $13-15$ & 4.92 & 5.11 & 0.76 & \\
& & $(>16)$ & 49.85 & 85.28 & 9.78 & \\
\hline
\end{tabular}

Table 9. Selected spectral information for $\mathrm{U}(5) \mathrm{F}_{6}-\mathrm{HF}$

\begin{tabular}{|c|c|c|c|c|c|c|}
\hline $\mathrm{H} / \mathrm{X}$ & $\mathrm{H} / \mathrm{U}$ & Group & $\underset{\%}{\text { Flux }}$ & $\begin{array}{c}\text { Absorptions } \\
\%\end{array}$ & $\begin{array}{c}\text { Fissions } \\
\%\end{array}$ & AEG \\
\hline 10 & 0.51 & $\begin{array}{c}<7 \\
8-9 \\
10-12 \\
13-15 \\
(>16)\end{array}$ & $\begin{array}{r}38.01 \\
33.59 \\
21.79 \\
4.33 \\
2.28\end{array}$ & $\begin{array}{r}9.85 \\
17.47 \\
41.88 \\
17.78 \\
13.02\end{array}$ & $\begin{array}{r}15.73 \\
8.72 \\
35.38 \\
13.31 \\
26.86\end{array}$ & 12.89 \\
\hline 50 & 2.53 & $\begin{array}{c}<7 \\
8-9 \\
10-12 \\
13-15 \\
(>16)\end{array}$ & $\begin{array}{r}42.46 \\
20.66 \\
19.09 \\
7.72 \\
9.97\end{array}$ & $\begin{array}{r}5.86 \\
5.04 \\
22.37 \\
19.14 \\
47.59\end{array}$ & $\begin{array}{r}6.73 \\
1.79 \\
11.70 \\
8.37 \\
71.41\end{array}$ & 19.73 \\
\hline 200 & 10.1 & $\begin{array}{c}<7 \\
8-9 \\
10-12 \\
13-15 \\
(>16)\end{array}$ & $\begin{array}{r}39.17 \\
14.36 \\
14.99 \\
7.74 \\
23.74\end{array}$ & $\begin{array}{r}2.80 \\
1.44 \\
9.79 \\
11.89 \\
74.08\end{array}$ & $\begin{array}{r}2.36 \\
0.43 \\
3.32 \\
3.06 \\
90.83\end{array}$ & 23.36 \\
\hline
\end{tabular}


A desirable characteristic of group cross sections is that the spectral flux used to generate the cross sections be similar to the spectral flux of the system being analyzed. As these two fluxes get farther apart, more energy groups are required to adequately represent the cross sections. As the generating flux and true flux become significantly different, it is likely that the library will yield unacceptable calculational results.

The information presented in Tables 7 through 9 is depicted graphically in Figs. 31-44. In each of these figures the fine-group (218-group) and broad-group (27-group) generating spectrums are shown as a function of energy.

For $\mathrm{UO}_{2} \mathrm{~F}_{2}$ at $\mathrm{H} / \mathrm{X}=5$, the $\mathrm{AEG}=10.08$ when using the SCALE 27-group library. This corresponds to an energy of about $3 \mathrm{keV}$. The majority of the flux is in the fission spectrum region with smaller, about equal amounts in the resolved and unresolved regions. There is a very small flux in the thermal region. The increased importance of the thermal flux over the fluxes in the other regions may be seen by the large fission contribution in the thermal region. This type of system tests the resonance region of the fissile material and the scattering matrices of the moderating material. One of the validation documents for KENO V.a and the SCALE 27-group library was reviewed to determine if this AEG range had been validated. ${ }^{28}$ The review indicated that AEGs greater than about 13 were validated for low-enriched uranium. Any systems with an AEG less than 13 must be considered outside the range of validation.

As the $\mathrm{H} / \mathrm{X}$ ratio is increased, the AEG becomes larger (the system becomes more thermal). The flux in the unresolved resonance region becomes smaller, and then the flux in the resolved resonance regions becomes smaller. The relative amount of fissions in the thermal region grows rapidly. The figures demonstrate that the AEG is closely related to the moderation level of the system. At an $H / X$ of about 20 , the AEG comes into the range of the validation. However, virtually all of the validation criticals in the AEG range from 13 to 20 involve heterogeneous systems or had highly enriched uranium drivers in order to reach criticality. It may not be appropriate to use AEG to relate homogeneous calculations to heterogeneous or driven benchmark experiments (i.e., the AEG of the unknown system is within the range of AEG validated, but the unknown system is outside the area of applicability of the validation).

There is good agreement between the generating flux and the calculated flux at $\mathrm{H} / \mathrm{X}=$ 200. It might be expected that the cross sections would be more reliable at this moderation level. The AEG for this range is on the order of 23. There appear to be numerous critical experiments with a calculated AEG between 22 and 25 . Above $H / X=200$, there is a gradual decrease in the flux in the resonance region; the flux in the fission spectrum region is nearly constant.

The flux plots for $1.4 \% \mathrm{UO}_{2} \mathrm{~F}_{2}-\mathrm{H}_{2} \mathrm{O}$ are similar to those for $5 \%$ enrichment, except there is a slight spectral hardening that can be seen in the AEG at a given $\mathrm{H} / \mathrm{X}$. The $5 \% \mathrm{UF}_{6}-\mathrm{HF}$ systems show a slight spectral softening when compared with the $5 \% \mathrm{UO}_{2} \mathrm{~F}_{2}-\mathrm{H}_{2} \mathrm{O}$ system at the $\mathrm{H} / \mathrm{X}$. The effects of enrichment on the AEG are given in Table 10 for several of the predicted critical systems from Sect. 2. 


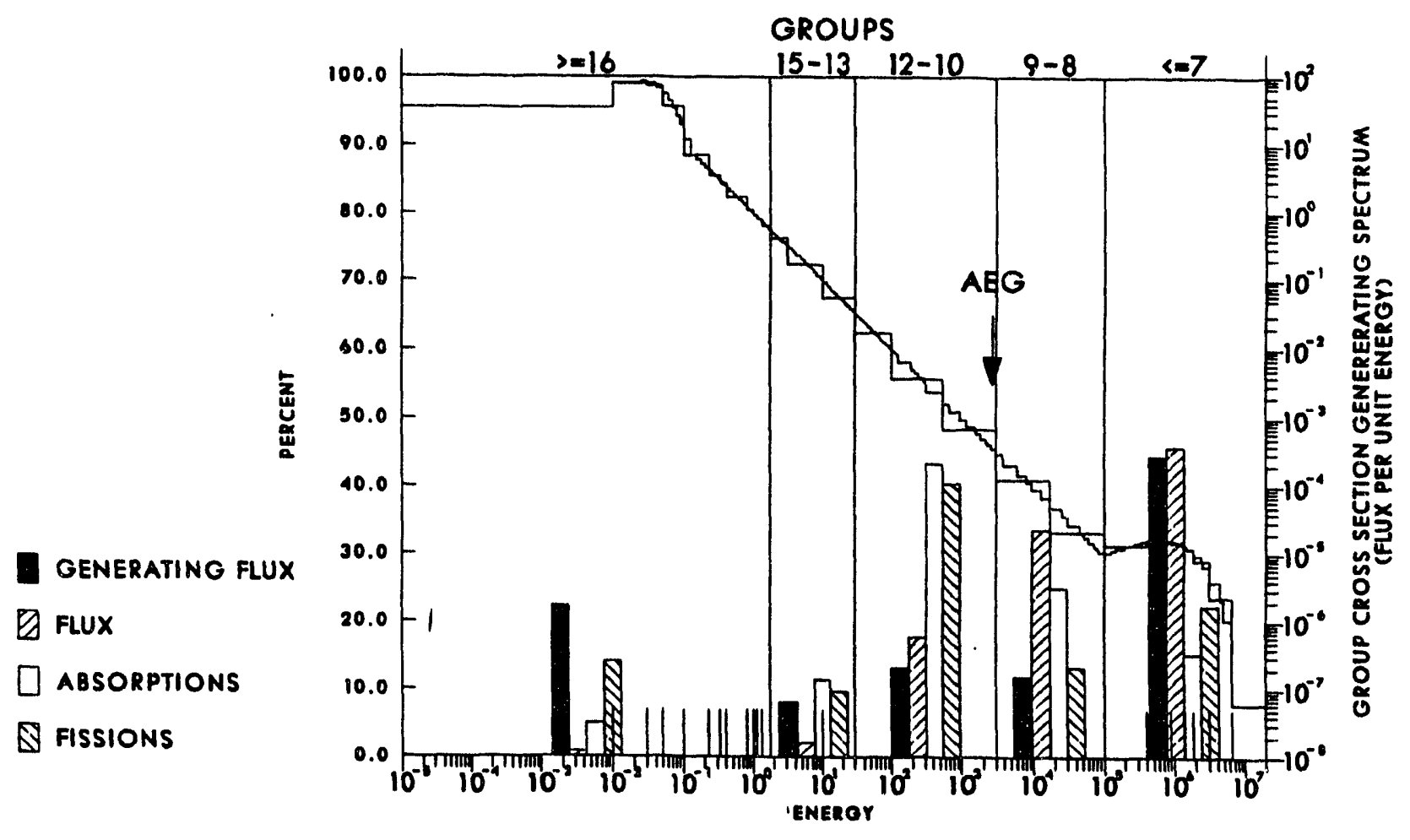

Fig. 31. $\mathrm{UO}_{2} \mathrm{~F}_{2}-\mathrm{H}_{2} \mathrm{O} 5.0 \%$ enriched $\mathrm{H} / \mathrm{X}=5$.

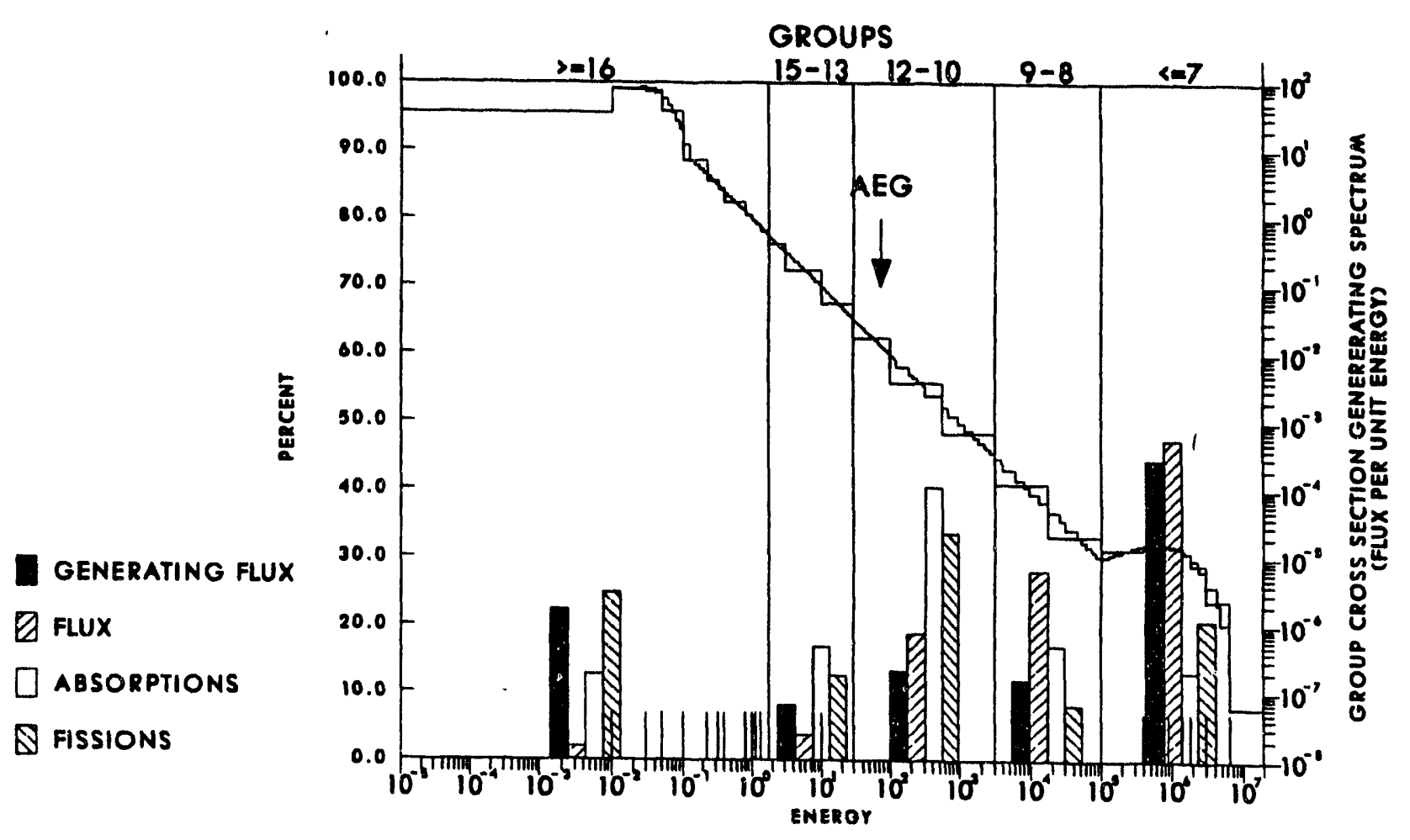

Fig. 32. $\mathrm{UO}_{2} \mathrm{~F}_{2}-\mathrm{H}_{2} \mathrm{O} 5.0 \%$ enriched $\mathrm{H} / \mathrm{X}=10$. 


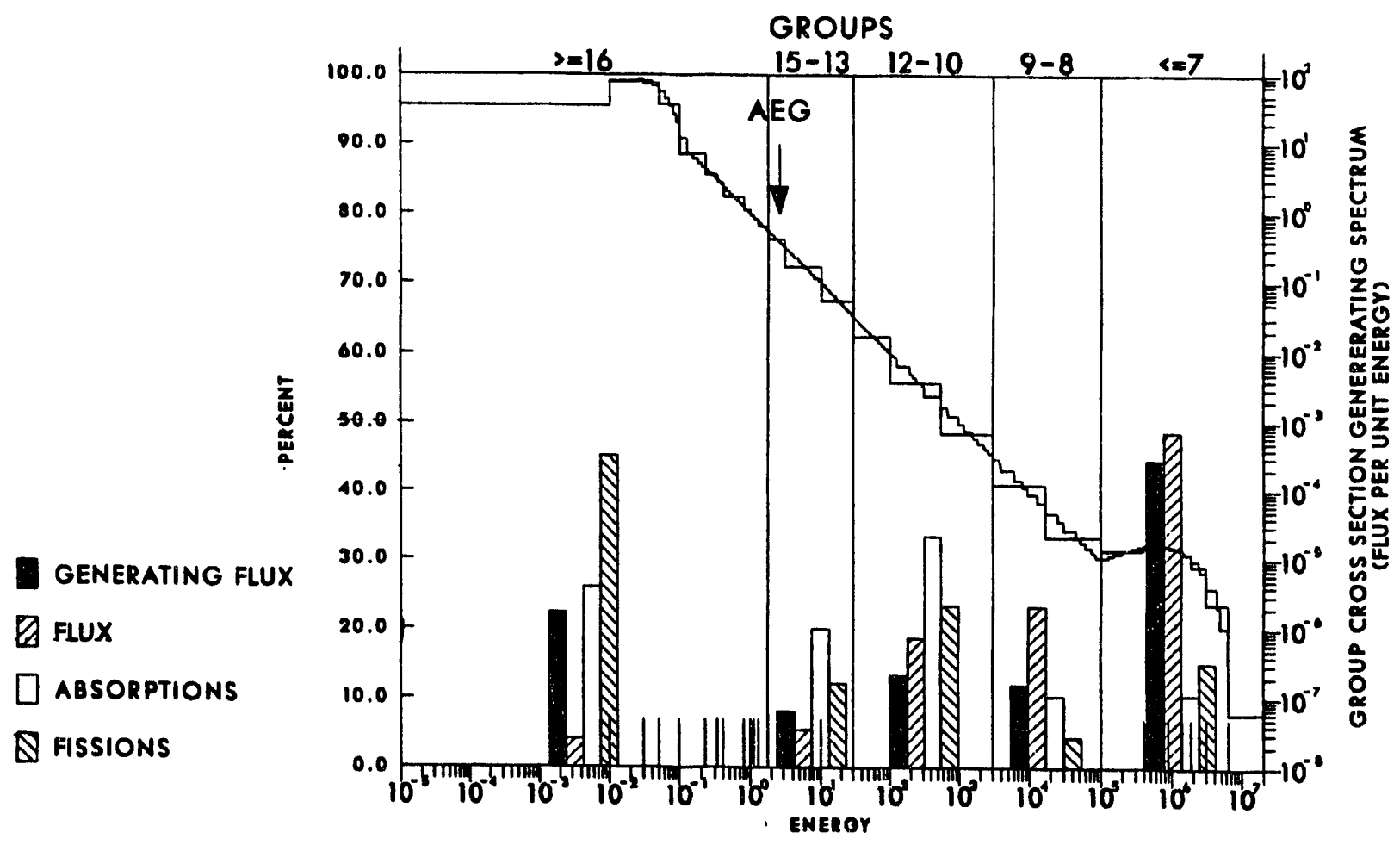

Fig. 33. $\mathrm{UO}_{2} \mathrm{~F}_{2}-\mathrm{H}_{2} \mathrm{O} 5.0 \%$ enriched $\mathrm{H} / \mathrm{X}=20$

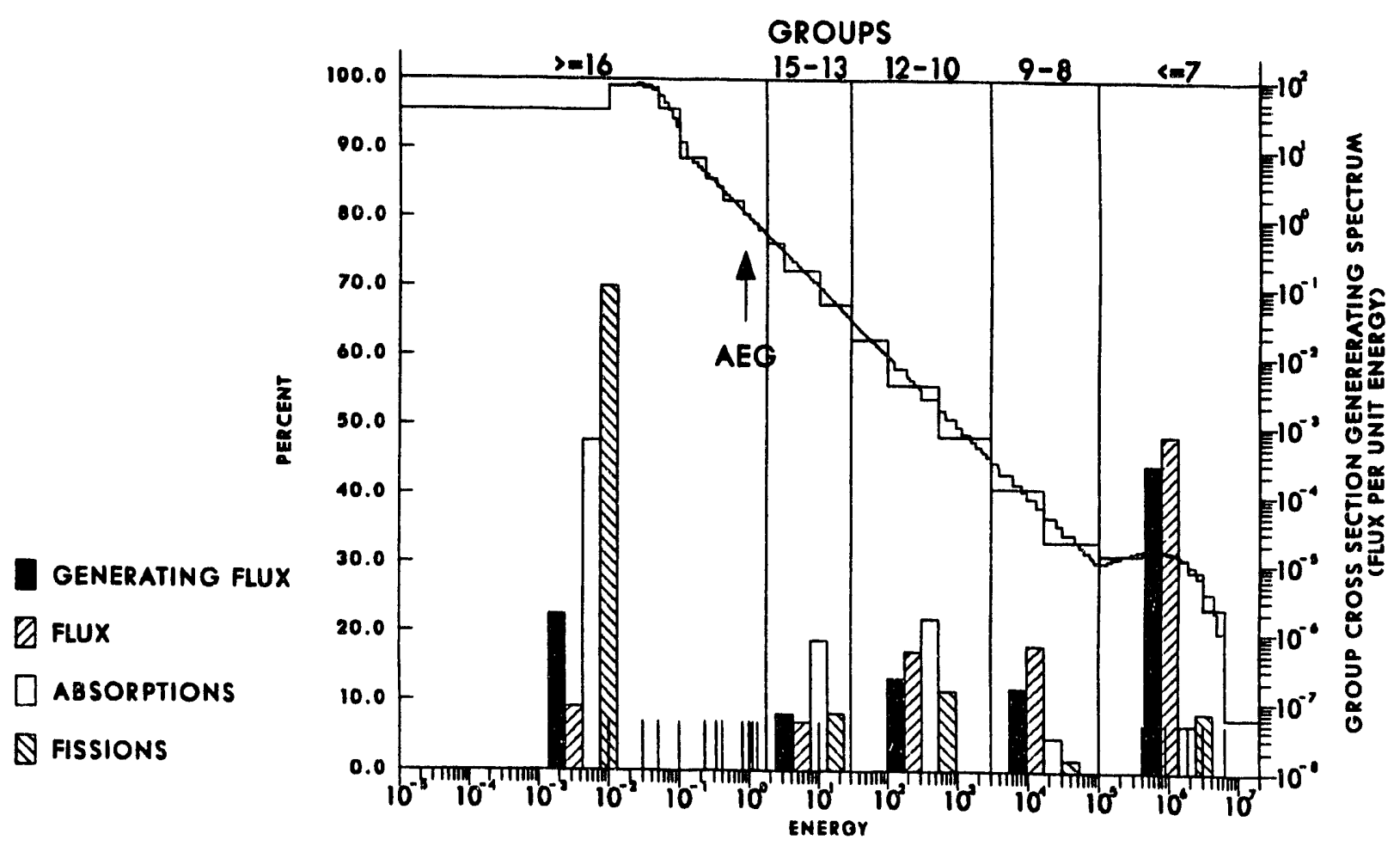

Fig. 34. $\mathrm{UO}_{2} \mathrm{~F}_{2}-\mathrm{H}_{2} \mathrm{O} 5.0 \%$ enriched $\mathrm{H} / \mathrm{X}=50$. 


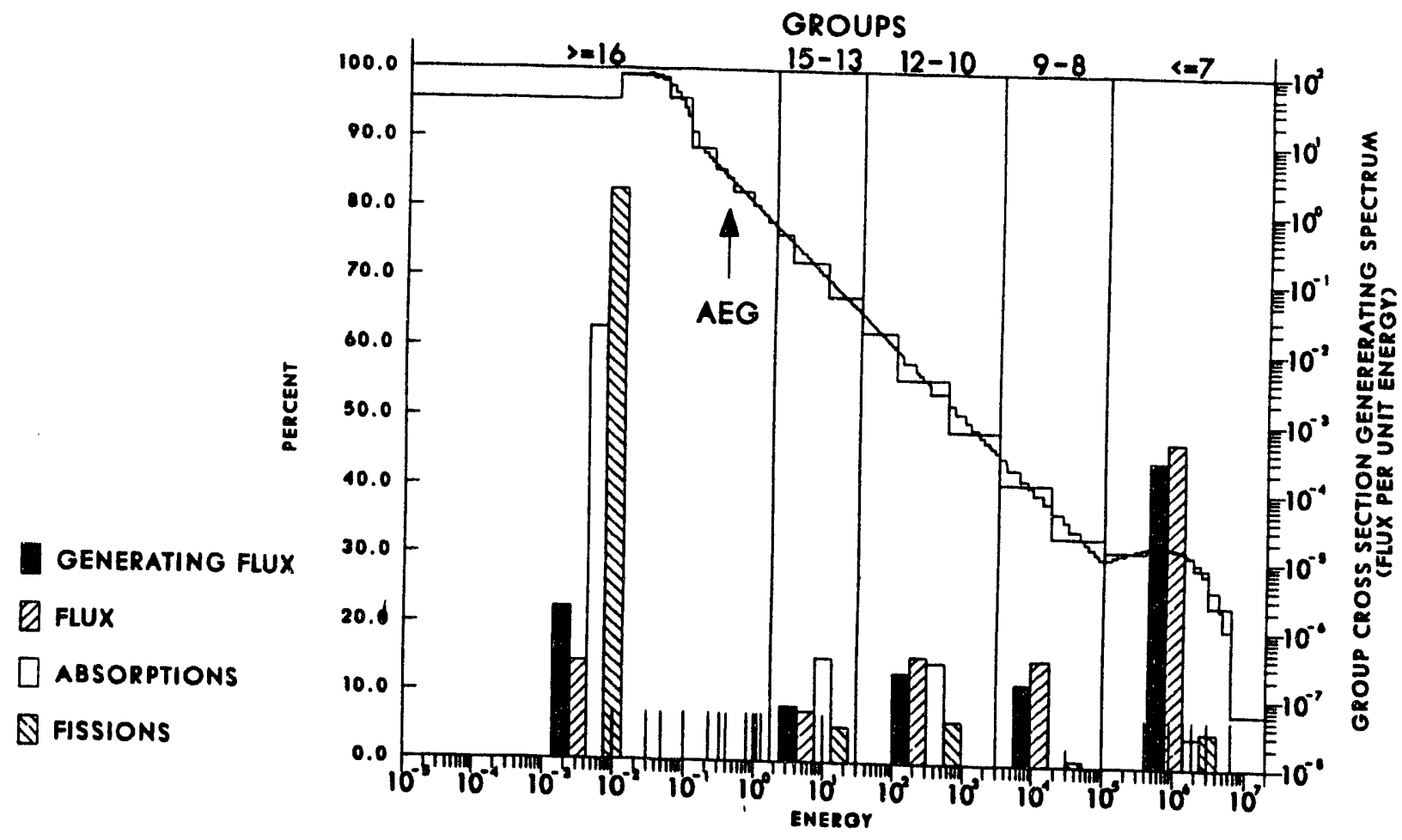

Fig. 35. $\mathrm{UO}_{2} \mathrm{~F}_{2}-\mathrm{H}_{2} \mathrm{O} 5.0 \%$ enriched $\mathrm{H} / \mathrm{X}=100$.

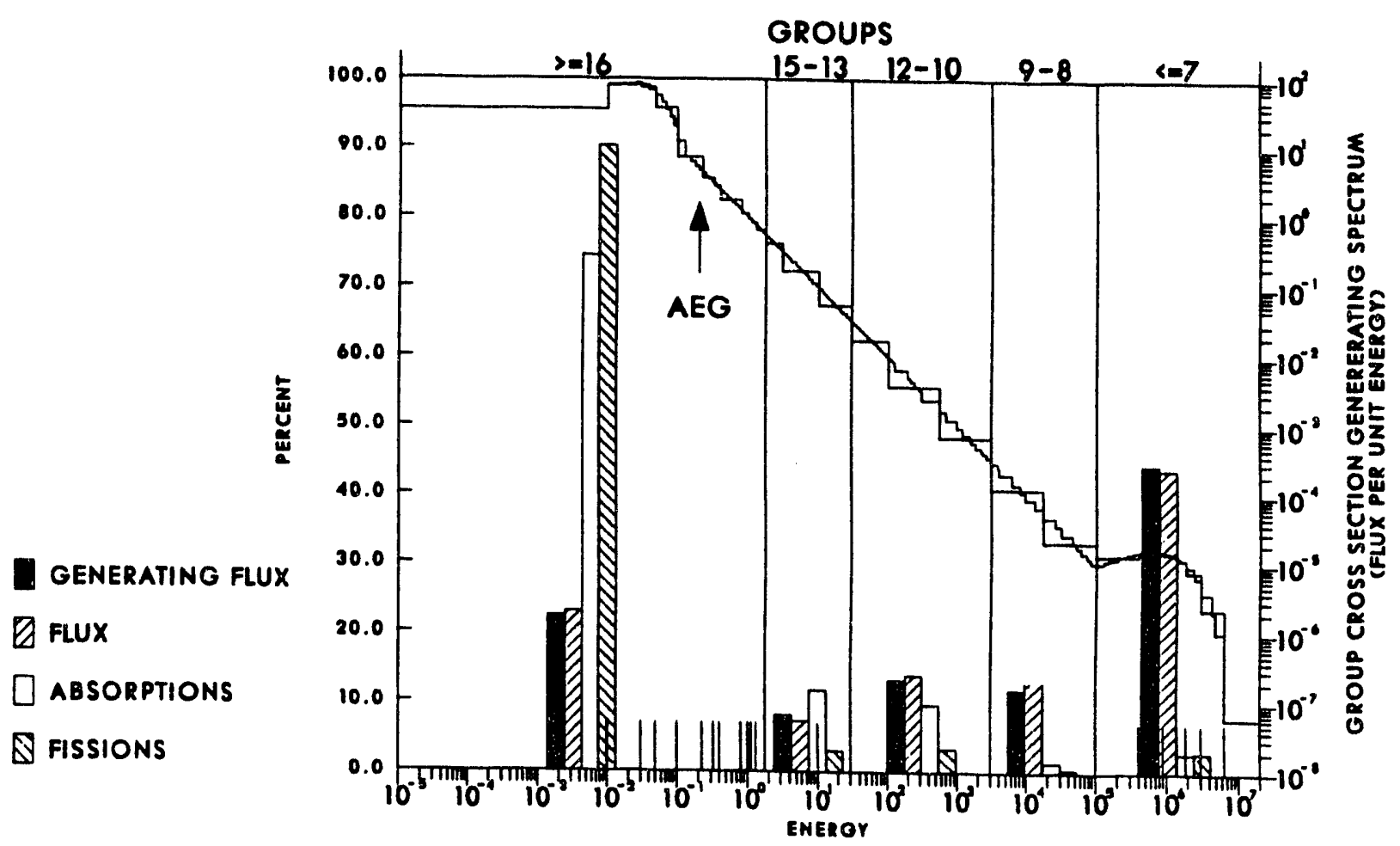

Fig. 36. $\mathrm{UO}_{2} \mathrm{~F}_{2}-\mathrm{H}_{2} \mathrm{O} 5.0 \%$ enriched $\mathrm{H} / \mathrm{X}=200$. 


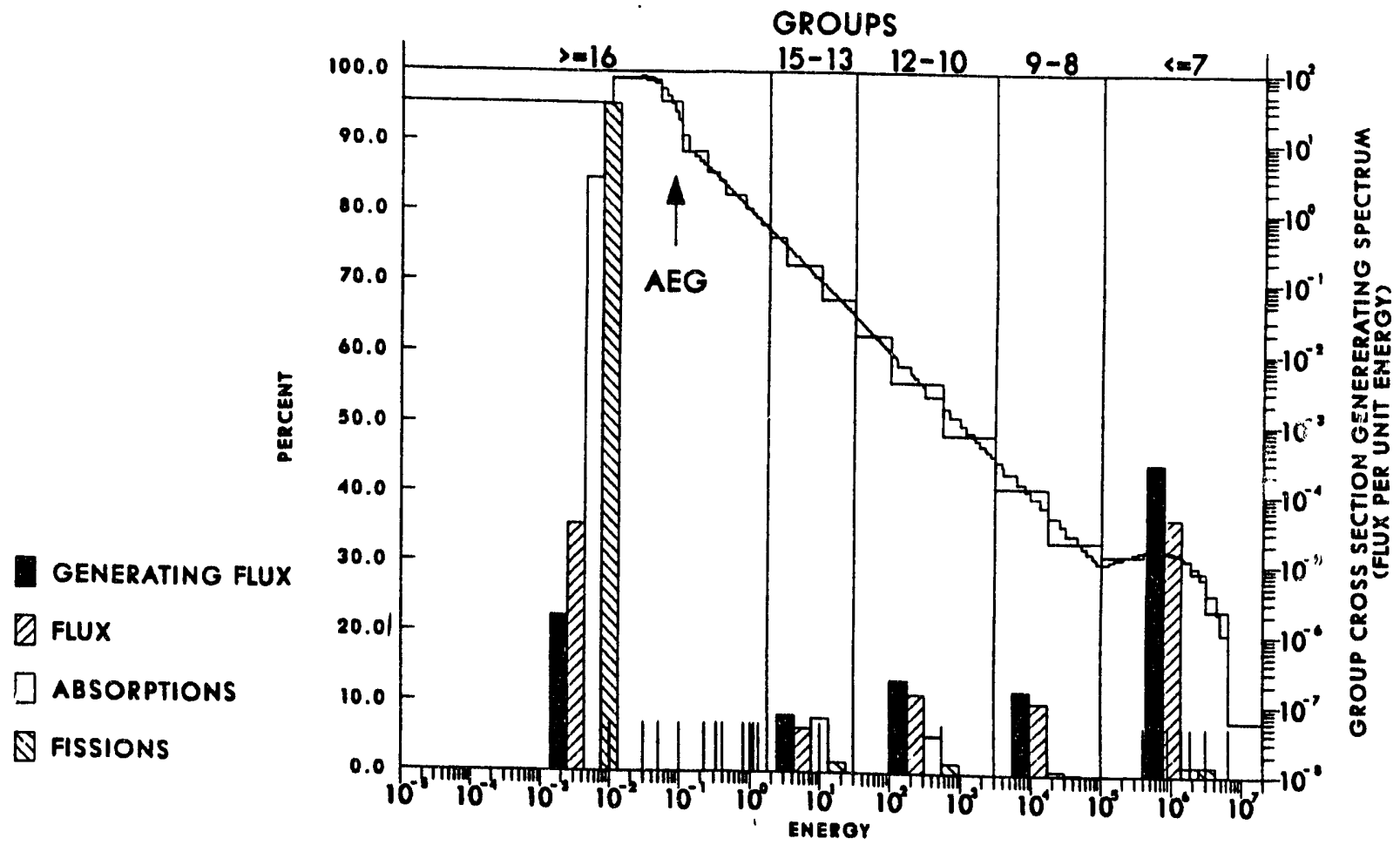

Fig. 37. $\mathrm{UO}_{2} \mathrm{~F}_{2}-\mathrm{H}_{2} \mathrm{O} 5.0 \%$ enriched $\mathrm{H} / \mathrm{X}=500$.

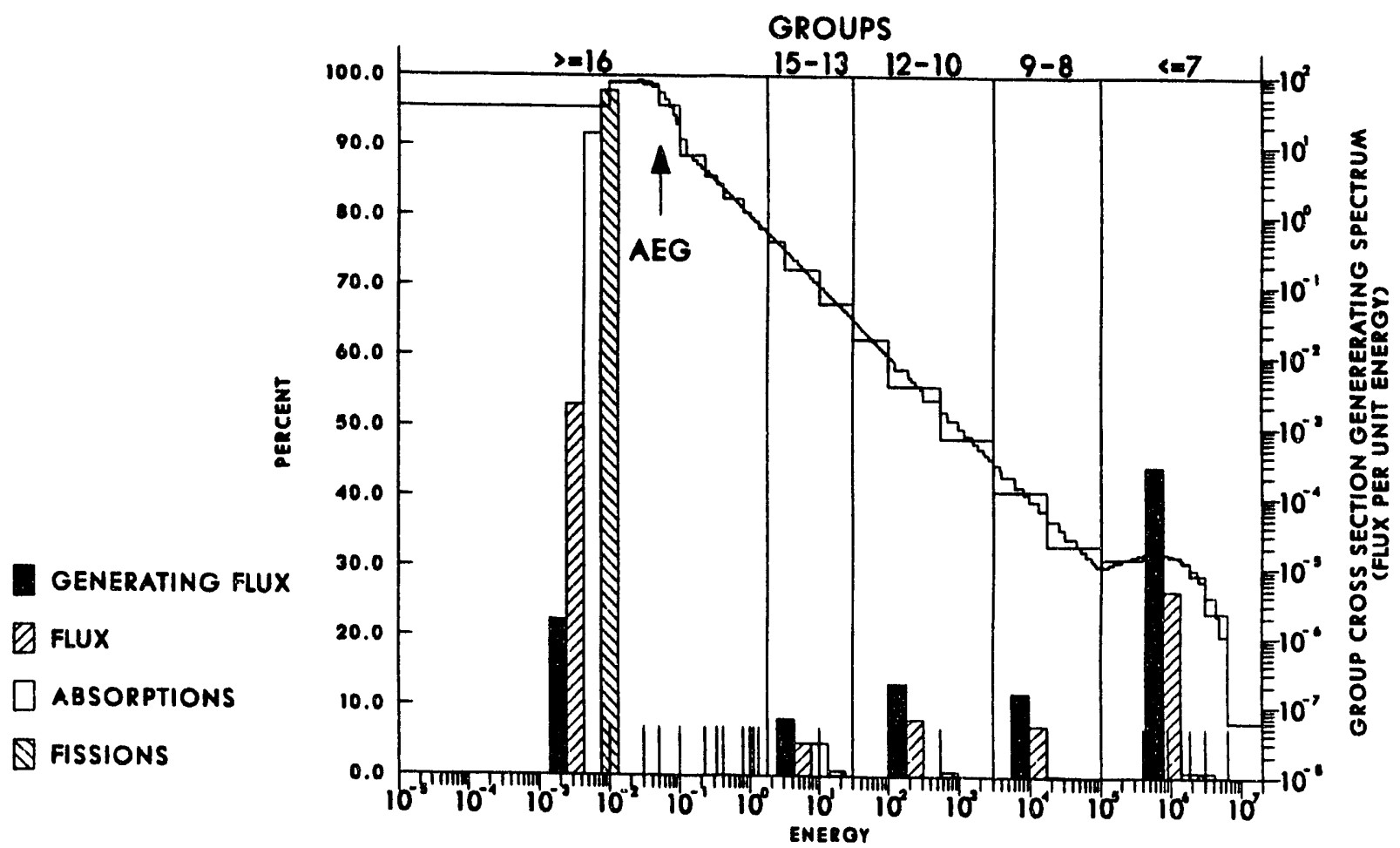

Fig. 38. $\mathrm{UO}_{2} \mathrm{~F}_{2}-\mathrm{H}_{2} \mathrm{O} 5.0 \%$ enriched $\mathrm{H} / \mathrm{X}=1500$. 


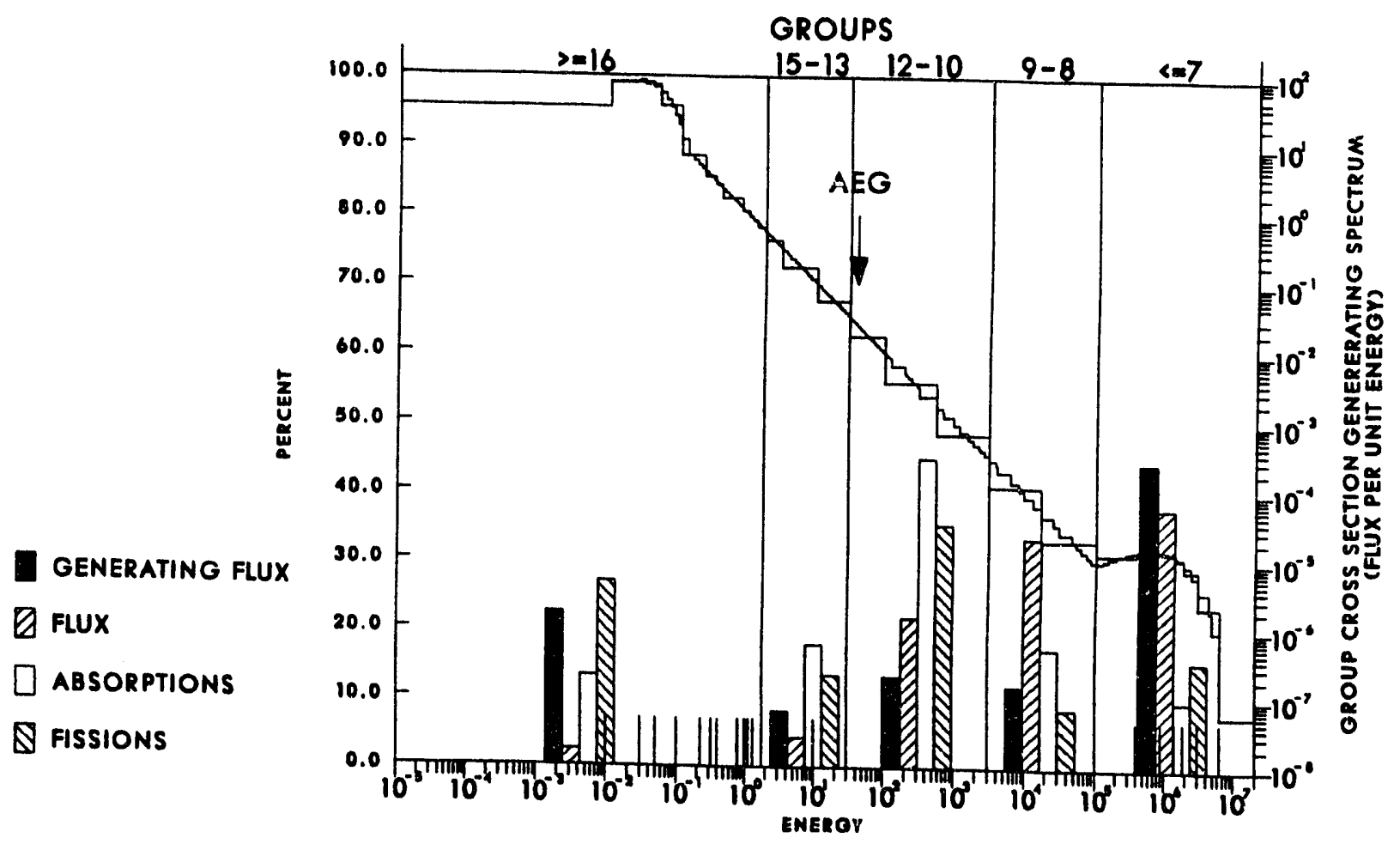

Fig. 39. $U_{6}-H F 5.0 \%$ enriched $H / X=10$.

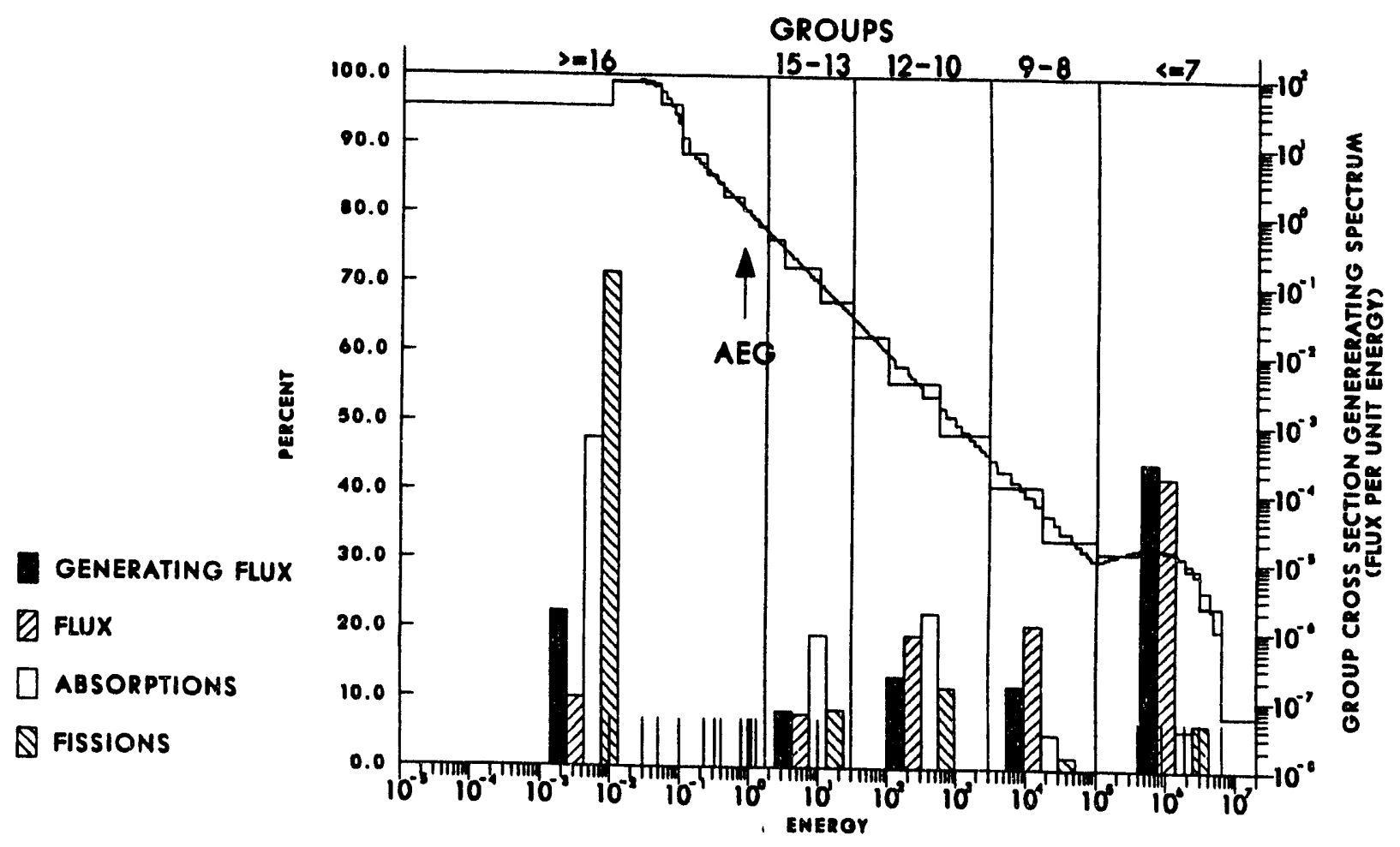

Fig. 40. $\mathrm{UF}_{6}$-HF $5.0 \%$ enriched $\mathrm{H} / \mathrm{X}=50$. 


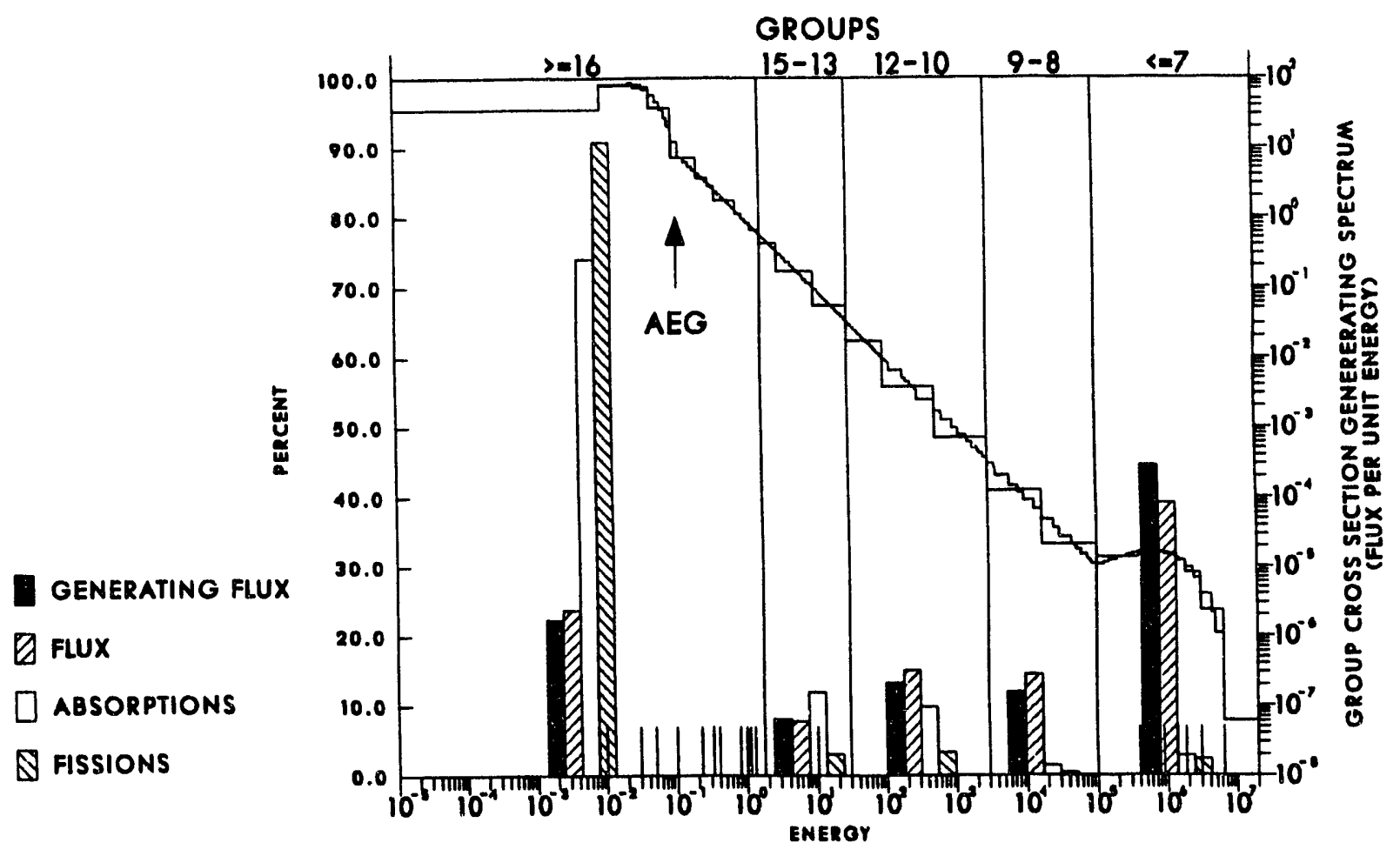

Fig. 41. $\mathrm{UF}_{6}-\mathrm{HF} 5.0 \%$ enriched $\mathrm{H} / \mathrm{X}=200$. 


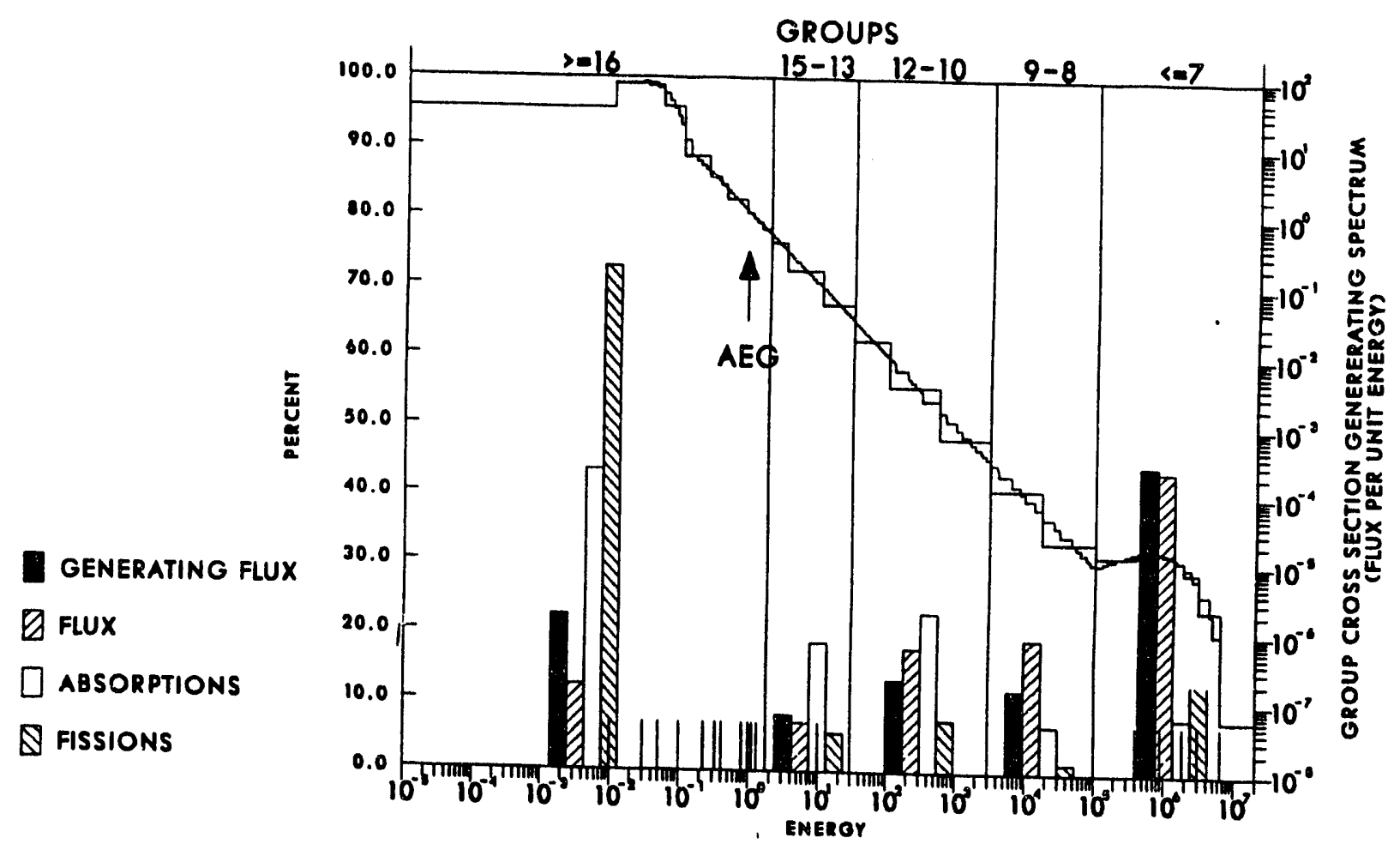

Fig. 42. $\mathrm{UO}_{2} \mathrm{~F}_{2}-\mathrm{H}_{2} \mathrm{O}$ 1.4\% Enriched $\mathrm{H} / \mathrm{X}=100$.

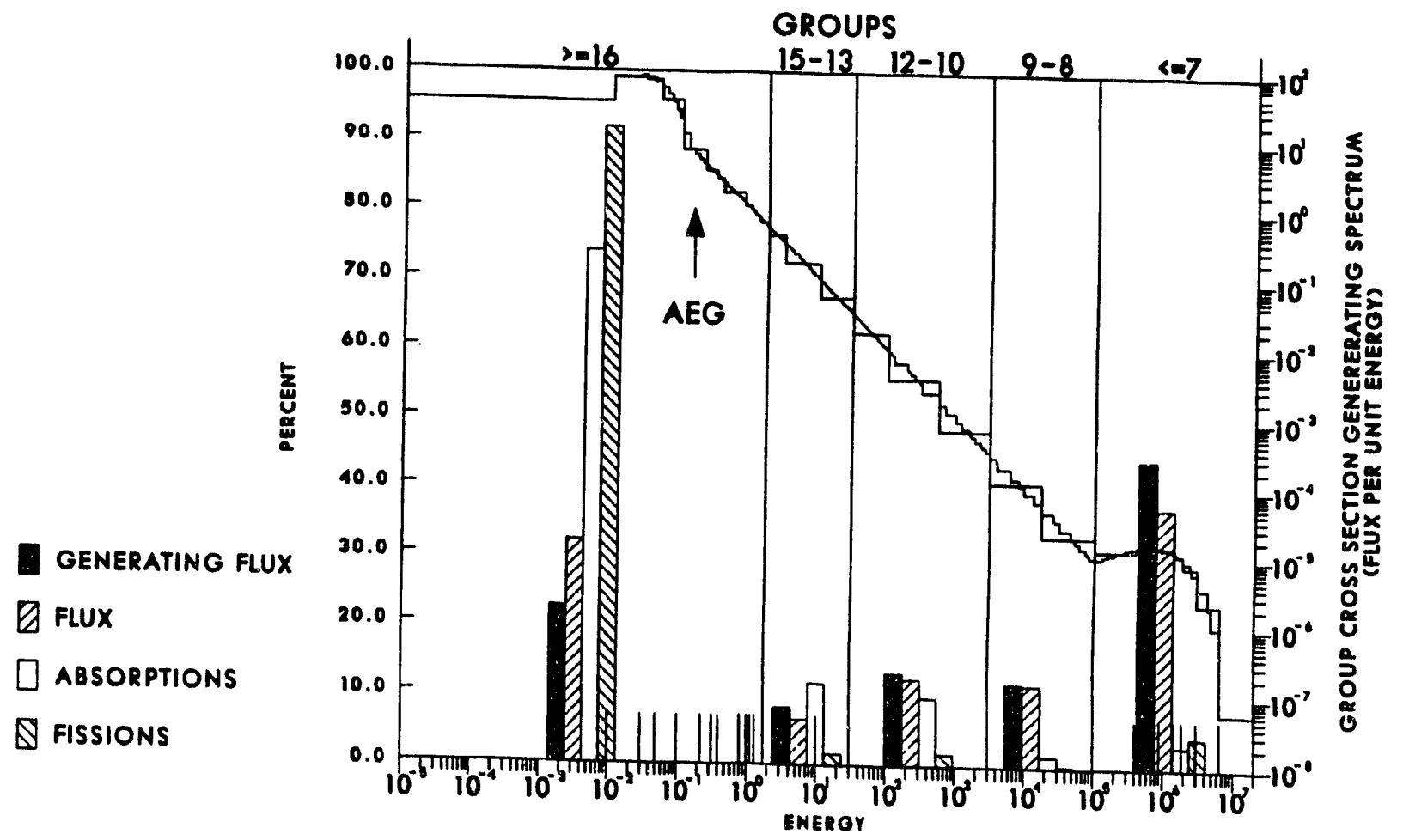

Fig. 43. $\mathrm{UO}_{2} \mathrm{~F}_{2}-\mathrm{H}_{2} \mathrm{O}$ 1.4\% Enriched $\mathrm{H} / \mathrm{X}=500$. 


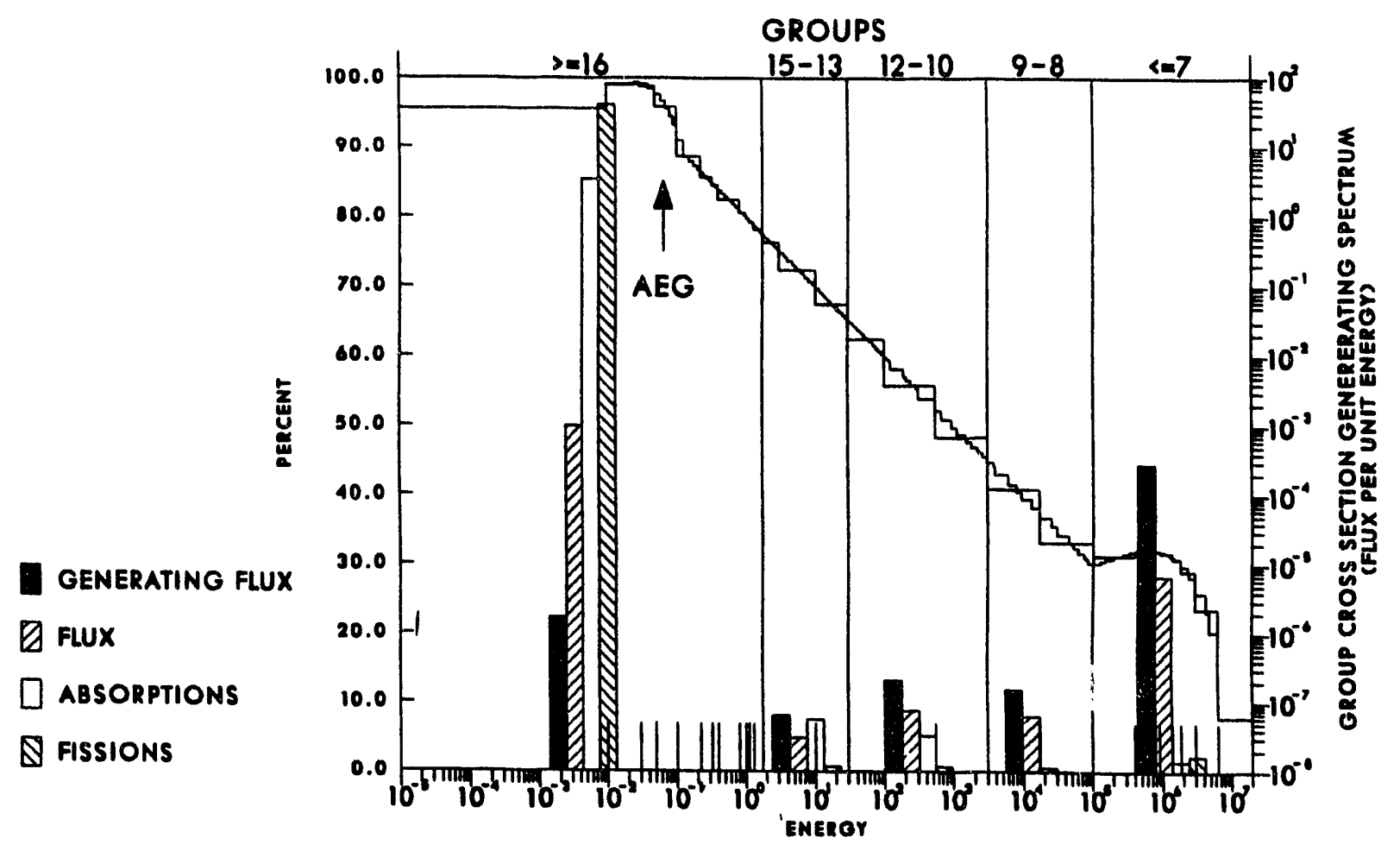

Fig. 44. $\mathrm{UO}_{2} \mathrm{~F}_{2}-\mathrm{H}_{2} \mathrm{O}$ 1.4\% Enriched $\mathrm{H} / \mathrm{X}=1500$. 
Table 10. AEG for several calculated critical spheres

\begin{tabular}{|c|c|c|c|c|}
\hline \multirow[t]{2}{*}{$\mathrm{UO}_{2} \mathrm{~F}_{2}-\mathrm{H}_{2} \mathrm{O}$} & \multirow{2}{*}{ Enrichment } & \multirow[b]{2}{*}{$\mathrm{H} / \mathrm{X}$} & \multicolumn{2}{|c|}{ KENO V.a Results } \\
\hline & & & $k_{\text {eff }} \pm \sigma$ & AEG \\
\hline & 5 & 100 & $0.9927 \pm 0.0041$ & 21.99 \\
\hline & 4 & 100 & $1.0054 \pm 0.0047$ & 21.77 \\
\hline & 3 & 100 & $0.9867 \pm 0.0038$ & 21.34 \\
\hline & 2 & 100 & $1.0018 \pm 0.0031$ & 20.59 \\
\hline & & 200 & $0.9904 \pm 0.0035$ & 22.34 \\
\hline & 1.7 & 200 & $0.9960 \pm 0.0030$ & 22.18 \\
\hline & 1.4 & 200 & $0.9949 \pm 0.0030$ & 22.83 \\
\hline \multicolumn{5}{|l|}{$\mathrm{UF}_{6}-\mathrm{HF}$} \\
\hline & 5 & 100 & $1.0007 \pm 0.0044$ & 22.24 \\
\hline & 4 & 100 & $0.9978 \pm 0.0041$ & 22.03 \\
\hline & 3 & 100 & $0.9937 \pm 0.0038$ & 21.66 \\
\hline & 2 & 200 & $0.9985 \pm 0.0033$ & 22.73 \\
\hline & 1.7 & 200 & $0.9980 \pm 0.0033$ & 22.54 \\
\hline & 1.4 & 200 & $0.9964 \pm 0.0024$ & 22.21 \\
\hline
\end{tabular}

Information derived from analyses similar to these could be useful for selecting critical experiments that test specific cross-section regions. If a cross-section inadequacy is suspected in some energy range, experiments could be chosen that have characteristics that enhance the flux in that energy range and increase the sensitivity to the inadequacy.

Further study should be performed related to the use of the AEG in grouping different types of critical experiments. There is evidence that the AEG should not be used for comparison of latticed or driven systems to homogeneous systems. Grouping of reflected systems and unreflected systems and systems of differing geometries by use of the AEG should be evaluated. It may be that more detailed information on the flux distribution, fissions, absorptions, and leakage should be used rather than the AEG. 


\section{REFERENCES}

1. Nuclear Criticality Safety in Operations with Fissionable Materials Outside Reactors, ANSI/ANS-8.1, American Nuclear Society, 1983.

2. Nuclear Safety Guide, NUREG/CR-0095 (ORNL/NUREG/CSD-6), 1TD-7016, Rev. 2, Union Carbide Corp., Nucl. Div., Oak Ridge Natl. Lab., June 1978.

3. Uranium Hexafluoride: A Manual of Good Handling Practices, ORO-651, Rev. 6, Analysas Corp., Oak Ridge, Tenn., October 1991.

4. SCALE: A Modular Code System for Performing Standardized Computer Analyses for Licensing Evaluation, NUREG/CR-0200, Rev. 4 (ORNL/NUREG/CSD-2/R4), Vols. I, II, and III (draft February 1990), Martin Marietta Energy Systems, Inc., Oak Ridge Natl. Lab. Available from Radiation Shielding Information Center as CCC-545.

5. W. C. Jordan, "SCALE Cross-Section Libraries," Sect. M4 of SCALE: A Modular Code System for Performing Standardized Computer Analyses for Licensing Evaluation, NUREG/CR-0200, Rev. 4 (ORNL/NUREG/CSD-2/R4), Vols. I, II, and III (draft February 1990), Martin Marietta Energy Systems, Inc., Oak Ridge Natl. Lab. Available from Radiation Shielding Information Center as CCC-545.

6. N. M. Greene et al., The LAW Library - A Multigroup Cross-Section Library for Use in Radioactive Waste Analysis Calculations, ORNL/CSD/TM-275, Martin Marietta Energy Systems, Inc., Oak Ridge Natl. Lab. (to be published).

7. L. M. Petrie and N. F. Cross, KENO N, An Improved Monte Carlo Criticality Program, ORNL-4938, Union Carbide Corp., Nucl. Div., Oak Ridge Natl. Lab., November 1975.

8. C. E. Newlon and A. J. Mallett, Hydrogen Moderation, A Primary Nuclear Safety Control for Handling and Transporting Low-Enrichment UF, K-1663, Union Carbide Corp., Nucl. Div., Oak Ridge Gaseous Diffusion Plant, May 31, 1968.

9. G. E. Hansen and W. H. Roach, Six- and Sixteen-Group Cross Sections for Fast and Intermediate Critical Assemblies, LAMS-2543, Los Alamos Scientific Laboratory, December 6, 1961.

10. W. W. Engle, Jr., A User's Manual for ANISN, A One-Dimensional Discrete Ordinates Transport Code with Anisotropic Scattering, K-1693, Union Carbide Corp., Nucl. Div., Oak Ridge Gaseous Diffusion Plant, March 1967.

11. R. M. Westfall and M. A. Bjerke, "An Interface-Currents Integral Transport Model for Treating Doubly Heterogeneous, Multisystem Geometries," Proc. of Topical Meeting on Computational Methods in Nuclear Engineering, Vol. II, pp. 7-71, American Nuclear Society (1979). 
12. N. M. Greene et al., "NITAWL-II: SCALE System Module for Performing Resonance Shielding and Working Library Production," Sect. F2 of SCALE: A Modular Code System for Performing Standardized Computer Analyses for Licensing Evaluation, NUREG/CR-0200, Rev. 4 (ORNL/NUREG/CSD-2/R4), Vols. I, II, and III (draft February 1990), Martin Marietta Energy Systems, Inc., Oak Ridge Natl. Lab. Available from Radiation Shielding Information Center as CCC-545.

13. H. E. Handler, Progress Repon on Experiments to Determine Infinite Multiplication Factors of Enriched $\mathrm{UO}_{3}-\mathrm{H}_{2} \mathrm{O}$ Mixtures, $\mathrm{HW}-51168$, Hanford Atomic Products Operation, July 1, 1957.

14. H. E. Handler and R. E. Trumble, Jr., Infinite Multiplication Constants of Enriched $\mathrm{UO}_{3^{-}}$ $\mathrm{H}_{2} \mathrm{O}$ Mixtures, Preliminary Report by Hanford Atomic Products Operation (no report number), October 16, 1957.

15. V. I. Neeley and H. E. Handler, Measurement of Multiplication Constant for Slightly Enriched Homogeneous $\mathrm{UO}_{3}$-Water Mixtures and Minimum Enrichment for Criticality, HW-70310, Hanford Atomic Products Operation, August 21, 1961.

16. N. F. Landers and L. M. Petrie, "CSAS4: An Enhanced Criticality Safety Analysis Module with an Optimum Pitch Search Option," Sect. C4 of SCALE: A Modular Code System for Performing Standardized Computer Analyses for Licensing Evaluation, NUREG/CR-0200, Rev. 4 (ORNL/NUREG/CSD-2/R4), Vols. I, II, and III (draft February 1990), Martin Marietta Energy Systems, Inc., Oak Ridge Natl. Lab. Available from Radiation Shielding Information Center as CCC-545.

17. N. M. Greene, "BONAMI-S: Resonance Self-Shielding by the Bondarenko Method," Sect. F1 of SCALE: A Modular Code System for Performing Standardized Computer Analyses for Licensing Evaluation, NUREG/CR-0200, Rev. 4 (ORNL/NUREG/CSD. 2/R4), Vols. I, II, and III (draft February 1990), Martin Marietta Energy Systems, Inc., Oak Ridge Natl. Lab. Available from Radiation Shielding Information Center as CCC545.

18. N. M. Greene and L. M. Petrie, "XSDRNPM-S: A One-Dimensional Discrete-Ordinates Code for Transport Analysis," Sect. F3 of SCALE: A Modular Code System for Performing Standardized Computer Analyses for Licensing Evaluation, NUREG/CR-0200, Rev. 4 (ORNL/NUREG/CSD-2/R4), Vols. I, II, and III (draft February 1990), Martin Marietta Energy Systems, Inc., Oak Ridge Natl. Lab. Available from Radiation Shielding Information Center as CCC-545.

19. R. D. Carter, G. R. Kiel, and K. R. Ridgway, Criticality Handbook, Vols. I-III, ARH-600, Atlantic Richfield Hanford Company, June 30, 1968.

20. H. C. Paxton et al., Critical Dimensions of Systems Containing ${ }^{235} U$, ${ }^{239} \mathrm{Pu}$, and ${ }^{233} \mathrm{U}$, TID7028, U.S. Atomic Energy Commission, June 1964.

21. J. T. Thomas, Ed., Nuclear Safety Guide, Rev. 2, Union Carbide Corp., Nucl. Div., June 1978. 
22. H. F. Henry et al., Criticality Data and Nuclear Safety Guide Applicable to the Oak Ridge Gaseous Diffusion Plant, K-1019, Union Carbide Corp., Nucl. Div., Oak Ridge Gaseous Diffusion Plant, May 22, 1959.

23. J. A. Bucholz and R. M. Westfall, "Reactivity Effect of Cross-Section Processing for Moist Bulk-Oxide Criticals," TANSAO-33, p. 368, American Nuclear Society (1979).

24. C. M. Hopper and J. P. Renier, "Expanded and Applied Sixteen Neutron-Energy-Group Cross-Section Library," TANSAO-61, p. 186, American Nuclear Society (1990).

25. W. R. Stratton, Critical Data and Factors Affecting Criticality of Single Homogeneous Units, LA-3612, Los Alamos Scientific Laboratory, September 1967.

26. G. R. Handley et al., Validation of the Monte Carlo Criticality Program KENO $I V$ and the Hansen-Roach Sixteen-Energy-Group-Cross Sections for High-Enriched Uranium Systems, Y-2234, Union Carbide Corporation, Nuclear Division, Oak Ridge Y-12 Plant, April 1981.

27. M. E. Easter, Validation of KENO V.a and Two Cross-Section Libraries for Criticality Calculations of Low-Enriched Uranium Systems, ORNL/CSD/TM-223, K/HS-74, Martin Marietta Energy Systems, Inc., Oak Ridge Natl. Lab., July 1985.

28. W. C. Jordan et al., Validation of KENO V.a Comparison with Critical Experiments, ORNL/CSD/TM-238, Martin Marietta Energy Systems, Inc., Oak Ridge Natl. Lab., December 1986. 


\section{APPENDIX A}

\section{DENSITY RELATIONSHIPS}

The purpose of this appendix is to present relationships for uranium density as a function of $\mathrm{H} / \mathrm{U}$ ratio for uranium compounds. Water and $\mathrm{HF}$ have been considered as the principal moderators. The density of homogeneous mixtures may be estimated based on the principle of additive molar volume. One form of this is given in Eq. (A.1), where the uranium density in a mixture is expressed as a function of the $\mathrm{H} / \mathrm{U}$ :

$$
\rho_{u}=\frac{M_{u}}{\frac{V_{u c}}{N}+\left(\frac{H}{U}-M * Y\right) * \frac{V_{m}}{M}},
$$

where

$\rho_{u}=$ uranium density,

$M_{u}=$ molecular weight of uranium at a given enrichment,

$V_{u c}=$ molar volume of the uranium compound $\left(M_{u d} \int \rho_{u c}\right)$,

$N=$ number of uranium atoms in the uranium compound,

$\frac{V_{u c}}{N}=$ specific molar volume of uranium compound,

$V_{m}=$ molar volume of the moderating compound $\left(M_{m} / \rho_{\mathrm{m}}\right)$,

$M=$ number of hydrogen atoms in the moderating compound,

$\frac{V_{m}}{M}=$ specific molar volume of hydrogenous compound,

$\frac{H}{U}=$ the $\mathrm{H} / \mathrm{U}$ moderating ratio,

$Y=\quad$ number of hydrated-moderating molecules in uranium compound (hydrated water for water-moderated systems, hydrated HF for HF moderated systems).

In Eq. (A.1) $M$ is used for molecular weight, $\rho$ is used for density, and $V$ is used for molar volume $(V=M / \rho)$. The subscripts $u, u c$, and $m$ refer to uranium, uranium compound, and moderating compound, respectively. The form of Eq. (A.1) is general and requires a minimum of tabulated data to represent a large number of systems. The "specific molar volume" $\left(V_{u c} / N\right.$ and $V_{m} / M$ ) used in Eq. (A.1) is a contrived quantity which is defined as the molar volume (the molecular weight of a compound divided by its density) divided by the number of atoms of the nuclide of interest in the compound, the number of uranium atoms for the compound and the number of hydrogen atoms for the hydrogenous moderator. Eq. (A.1) could be simplified but, in doing so, the physical significance of the quantities which are involved is lost. As it stands, Eq. (A.1) is quite general and may be easily adapted for use on more complex mixtures and solutions. 
The quantity defined as the specific molar volume has the interesting property that the ratio of the molecular weight of a compound divided by the theoretical density of that compound is nearly constant, independent of the isotopic distribution of the elements in the molecule. For example, the specific molar volume for the uranium compound is independent of the uranium enrichment in the compound. This is because the theoretical density of the uranium compound has the same variation with enrichment as the molecular weight of uranium. Table A.1 lists several uranium compounds and moderating materials. The molecular weight and theoretical densities are given along with the specific molar volumes. Variations of the theoretical density of the mixtures due to temperature may be taken into account by using the appropriate theoretical density of the compound in computing the specific molar volume. The values listed in Table A.1 are based on a temperature of $23^{\circ} \mathrm{C}$. The density variation as a function of temperature is given in Table A.2 for several of the compounds.

The use of Eq. (A.1) with the specific molar volumes given in Table A.1 should yield maximum uranium densities for a given $\mathrm{H} / \mathrm{U}$ and are therefore conservative. (Note that the molecular weights given in Table A.1 are not consistent with those in SCALE-4.0. The molecular weights in Table A.1 are those values that were used in the original testing of the density relationships. Revising the molecular weights to those in SCALE-4.0 would not significantly affect the specific molar volumes tabulated, but revisions were not done here to maintain traceability to my notes.)

Uranyl fluoride and uranyl nitrate form solutions when moderated by water. They also form water hydrates at low $\mathrm{H} / \mathrm{U}$ ratios. This complicates the theoretical predictions of the uranium density. Because of these characteristics, the uranyl fluoride and uranyl nitrate systems have been treated in more detail.

E. J. Barber suggested that the relationship for uranyl fluoride be discontinuous at $\mathrm{H} / \mathrm{U}=4$ in order to account for the various hydrates which exist. Only mixtures of hydrated salts exist at $\mathrm{H} / \mathrm{U}<4$. Given this consideration, the density of uranyl fluoride may be estimated by Eqs. (A.2) and (A.3), where Eq. (A.3) is the specific form of Eq. (A.1). 
Table A.1. Properties of uranium and moderating compounds

\begin{tabular}{|c|c|c|c|c|}
\hline Compound & $\begin{array}{c}\text { Molecular } \\
\text { weight } \\
\left(\mathrm{M}^{\circ}\right)\end{array}$ & $\begin{array}{l}\mathrm{Wt} \% \mathrm{U} \\
\text { in } \\
\text { compound }\end{array}$ & $\begin{array}{l}\text { Density } \\
\text { (g/cc) } \\
@ 23^{\circ} \mathrm{C}\end{array}$ & $\begin{array}{l}\text { Specific molar } \\
\text { volume } \\
\left(\mathrm{V}_{\mathrm{uc}} / \mathrm{N}\right) \text { or }\left(\mathrm{V}_{\mathrm{m}} / \mathrm{M}\right)\end{array}$ \\
\hline $\mathbf{U}$ & 238.029 & 100.00 & 19.05 & 12.4950 \\
\hline $\mathrm{UO}_{2}$ & 270.028 & 88.15 & 10.96 & 24.6376 \\
\hline $\mathrm{U}_{3} \mathrm{O}_{8}$ & 842.082 & 84.80 & 8.30 & 33.8187 \\
\hline $\mathrm{UF}_{6}($ solid $)$ & 352.019 & 67.62 & $5.075^{\circledR}$ & 69.3633 \\
\hline $\mathrm{UO}_{2} \mathrm{~F}_{2}-2 \mathrm{H}_{2} \mathrm{O}$ & 344.057 & 69.18 & 4.76 & 72.2809 \\
\hline $\mathrm{UO}_{2}\left(\mathrm{NO}_{3}\right)_{2} \cdot 6 \mathrm{H}_{2} \mathrm{O}$ & 502.134 & 47.40 & $2.745^{\mathrm{a}}$ & 182.927 \\
\hline $\mathrm{H}_{2} \mathrm{O}$ & 18.016 & --- & $0.9977^{a}$ & 9.0287 \\
\hline HF(liquid) & 20.0063 & -- & $0.9516^{2}$ & 21.0239 \\
\hline $\mathrm{HNO}_{3}$ & 63.0128 & -- & 1.9447 & 32.4023 \\
\hline
\end{tabular}

'The density is a function of temperature as given in Table 2.

The tabulated volume is at $23^{\circ} \mathrm{C}$.

Table A.2. Temperature variation of several compounds

\begin{tabular}{llc}
\hline \multicolumn{1}{c}{ Compound } & \multicolumn{1}{c}{ Density @ $\mathrm{t}{ }^{\circ} \mathrm{C}(\mathrm{g} / \mathrm{cc})$} & Notes \\
\hline $\mathrm{UF}_{6}$ (solid) & $5.194-0.005168^{*} \mathrm{t}$ & $(1)$ \\
$\mathrm{UF}_{6}$ (liquid) & $1.670+0.15203^{*}(230.2-\mathrm{t})^{1 / 2}$ & $(2)$ \\
$\mathrm{UO}_{2}\left(\mathrm{NO}_{3}\right)_{2} \cdot 6 \mathrm{H}_{2} \mathrm{O}$ & $2.745^{*}\left[1-(\mathrm{t}-23 .)^{*} 0.0015\right]$ & $(3)$ \\
$\mathrm{H}_{2} \mathrm{O}$ & $0.99987 /\left(1 .-6.427-5^{*} \mathrm{t}+8.5053-6^{*} \mathrm{t}^{2}-6.79-8^{*} \mathrm{t}^{3}\right)$ & $(4)$ \\
$\mathrm{HF}($ liquid) & $1.0020-0.0022625^{*} \mathrm{t}+3.125-6^{*} \mathrm{t}^{2}$ & $(5)$ \\
$\mathrm{HF}($ solid) & $1.562-0.000979^{*} \mathrm{t}$ & $(5)$ \\
$\mathrm{HNO}$ & & $(3)$ \\
\hline
\end{tabular}

'Sources of data:

(1) E. J. Barber, Estimation of Pressures Developed by Retrained Solid UF K/ET-307 (1979).

(2) E. J. Barber, Relationship of Pressure to Temperature Rise in Overfilled Cylinders," K/ET-194 (1979).

(3) Fit to measured data by W. C. Jordan, ORNL, 1988.

(4) Fit to specific volume data for water $15<\mathrm{t}<30^{\circ} \mathrm{C}$.

(5) I. G. Ryss, Chemistry of Fluorine and Its Inorganic Compounds, AEC-tr-3927 Part 1, Chapter 3 - Hydrogen Flouride. Data for solid - p. 65 (LeBoucher, Fischer, Biltz). Data for liquid p. 66 (Simons and Bouknight). 


\section{URANYL FLUORIDE}

$\mathrm{H} / \mathrm{U}<4$

$$
\rho_{u}=4.96-0.32 *\left(\frac{H}{U}\right) \text {. }
$$

$\mathrm{H} / \mathrm{U} \geq 4$

$$
\rho_{u}=\frac{M_{u}}{V_{U O_{2} F_{2} * 2 H_{2} \mathrm{O}}+\left(\frac{H}{U}-4\right) * \frac{V_{\mathrm{H}_{2} \mathrm{O}}}{2}}
$$

\section{URANYL NITRATE}

$$
P_{u}=\frac{M_{u} *\left[1+\frac{M^{*}}{1000} *\left(V_{H_{2} O}-V_{H N O_{3}}\right)\right]}{V_{U N H}+\left(\frac{H}{U}-12\right) * \frac{V_{H_{2} O}}{2}} .
$$

It was found that, for uranyl nitrate, the use of theoretical densities in Eq. (A.1) did not yield accurate uranium densities over the full range of $\mathrm{H} / \mathrm{U}$. In addition, the inclusion of the excess acid into Eq. (A.1) and the use of theoretical densities for the excess acid gave unreasonable density effects. The molar volume of uranyl nitrate hexahydrate and nitric acid given in Table A.1 were adjusted for a best fit to data on uranyl nitrate solutions with excess acid using Eq. (A.4). Equation (A.4) is the specific form of Eq. (A.1) for uranyl nitrate, including the excess acid. Equation (A.4) is similar to that in ARH-600, but is believed to be a better estimate for the nitric acid system.

Mixtures of various hydrate forms must be assumed for $\mathrm{H} / \mathrm{U}$ ratios less than 12 in uranyl nitrate systems. Only limited information was found for these systems. It is believed that the formulations in Eq. (A.4) may significantly overpredict uranium densities at $\mathrm{H} / \mathrm{U}<12$.

Table A.3 gives the theoretical density for $\mathrm{UO}_{2} \mathrm{~F}_{2}-\mathrm{H}_{2} \mathrm{O}$ mixtures as predicted by Eqs. (A.2) and (A.3). Table A.4 gives the theoretical density for $\mathrm{UF}_{6}-\mathrm{HF}$ mixtures as predicted by Eq. (A.1). Tables A.3 and A.4 were used in the calculations presented in Sect. 2. Tables A.3 and $\mathrm{A} .4$ list the physical properties of $\mathrm{UO}_{2} \mathrm{~F}_{2}-\mathrm{H}_{2} \mathrm{O}$ and $\mathrm{UF}_{6}-\mathrm{HF}$ mixtures predicted at $20^{\circ} \mathrm{C}$. The uranium density, uranium compound density, and moderator densities are tabulated for the specified $\mathrm{H} / \mathrm{X}$ (and corresponding $\mathrm{H} / \mathrm{U}$ ) moderation ratios. Uranium enrichments of $5,4,3,2$, 1.7 , and $1.4 \%{ }^{235} \mathrm{U}$ were considered. 
Table A.3. Physical properties of $\mathrm{UO}_{2} \mathrm{~F}_{2}-\mathrm{H}_{2} \mathrm{O}$ mixtures

\begin{tabular}{|c|c|c|c|c|}
\hline \multirow[b]{2}{*}{$\mathrm{H} / \mathrm{X}$} & \multicolumn{3}{|c|}{$\mathrm{UO}_{2} \mathrm{~F}_{2}-\mathrm{H}_{2} \mathrm{O}$} & \multirow[b]{2}{*}{$\mathrm{H}_{2} \mathrm{O}$ den. } \\
\hline & $\mathrm{H} / \mathrm{U}$ & U den. & $\mathrm{UO}_{2} \mathrm{~F}_{2}$ den. & \\
\hline \multicolumn{5}{|c|}{$5.0 \mathrm{E}+00 \%$ Enriched } \\
\hline $5.000 \mathrm{E}+00$ & 2.532E-01 & $4.8790 E+00$ & $6.3143 E+00$ & 4.6776E-02 \\
\hline $1.000 \mathrm{E}+01$ & 5.064E-01 & $4.7980 \mathrm{E}+00$ & $6.2095 \mathrm{E}+00$ & 9.1999E-02 \\
\hline $2.000 \mathrm{E}+01$ & $1.013 E+00$ & $4.6359 \mathrm{E}+00$ & $5.9997 \mathrm{E}+00$ & 1.7778E-01 \\
\hline $5.000 \mathrm{E}+01$ & $2.532 \mathrm{E}+00$ & $4.1498 E+00$ & $5.3706 \mathrm{E}+00$ & 3.9785E-01 \\
\hline $1.000 \mathrm{E}+02$ & $5.064 \mathrm{E}+00$ & $2.9054 \mathrm{E}+00$ & $3.7601 E+00$ & 5.5710E-01 \\
\hline $2.000 \mathrm{E}+02$ & $1.013 \mathrm{E}+01$ & $1.8648 \mathrm{E}+00$ & $2.4134 \mathrm{E}+00$ & 7.1513E-01 \\
\hline $3.000 \mathrm{E}+02$ & $1.519 \mathrm{E}+01$ & $1.3730 \mathrm{E}+00$ & $1.7769 \mathrm{E}+00$ & $7.8980 \mathrm{E}-01$ \\
\hline $5.000 \mathrm{E}+02$ & $2.532 \mathrm{E}+01$ & 8.9889E-01 & $1.1633 \mathrm{E}+00$ & 8.6180E-01 \\
\hline $7.000 \mathrm{E}+02$ & $3.545 \mathrm{E}+01$ & 6.6817E-01 & 8.6474E-01 & 8.9683E-01 \\
\hline $1.000 \mathrm{E}+03$ & $5.064 \mathrm{E}+01$ & 4.8243E-01 & $6.2436 \mathrm{E}-01$ & $9.2504 \mathrm{E}-01$ \\
\hline $1.500 \mathrm{E}+03$ & $7.596 \mathrm{E}+01$ & $3.2968 \mathrm{E}-01$ & 4.2667E-01 & 9.4824E-01 \\
\hline $2.000 E+03$ & $1.013 E+02$ & $2.5040 \mathrm{E}-01$ & 3.2407E-01 & 9.6027E-01 \\
\hline \multicolumn{5}{|c|}{$4.0 \mathrm{E}+00 \%$ Enriched } \\
\hline $5.000 \mathrm{E}+00$ & $2.026 \mathrm{E}-01$ & $4.8952 \mathrm{E}+00$ & $6.3351 \mathrm{E}+00$ & 3.7540E-02 \\
\hline $1.000 \mathrm{E}+01$ & 4.051E-01 & $4.8304 E+00$ & $6.2512 \mathrm{E}+00$ & 7.4087E-02 \\
\hline $2.000 \mathrm{E}+01$ & 8.102E-01 & $4.7007 E+00$ & $6.0834 \mathrm{E}+00$ & $1.4420 \mathrm{E}-01$ \\
\hline $5.000 \mathrm{E}+01$ & $2.026 \mathrm{E}+00$ & $4.3118 E+00$ & $5.5801 \mathrm{E}+00$ & 3.3067E-01 \\
\hline $1.000 \mathrm{E}+02$ & $4.051 E+00$ & $3.2708 \mathrm{E}+00$ & $4.2330 \mathrm{E}+00$ & 5.0167E-01 \\
\hline $2.000 \mathrm{E}+02$ & $8.102 E+00$ & $2.1769 E+00$ & $2.8172 \mathrm{E}+00$ & $6.6777 \mathrm{E}-01$ \\
\hline $3.000 \mathrm{E}+02$ & $1.215 \mathrm{E}+01$ & $1.6313 \mathrm{E}+00$ & $2.1111 \mathrm{E}+00$ & 7.5061E-01 \\
\hline $5.000 \mathrm{E}+02$ & $2.026 \mathrm{E}+01$ & $1.0866 \mathrm{E}+00$ & $1.4062 \mathrm{E}+00$ & 8.3331E-01 \\
\hline $7.000 \mathrm{E}+02$ & $2.836 \mathrm{E}+01$ & 8.1462E-01 & $1.0542 \mathrm{E}+00$ & 8.7461E-01 \\
\hline $1.000 \mathrm{E}+03$ & $4.051 \mathrm{E}+01$ & $5.9225 \mathrm{E}-01$ & $7.6646 \mathrm{E}-01$ & 9.0838E-01 \\
\hline $1.500 \mathrm{E}+03$ & $6.077 \mathrm{E}+01$ & 4.0705E-01 & $5.2679 \mathrm{E}-01$ & 9.3649E-01 \\
\hline $2.000 \mathrm{E}+03$ & $8.102 E+01$ & 3.1009E-01 & 4.0130E-01 & 9.5122E-01 \\
\hline \multicolumn{5}{|c|}{$3.0 \mathrm{E}+00 \%$ Enriched } \\
\hline $5.000 \mathrm{E}+00$ & $1.519 \mathrm{E}-01$ & $4.9114 \mathrm{E}+00$ & $6.3559 E+00$ & $2.8245 E-02$ \\
\hline $1.000 \mathrm{E}+01$ & 3.038E-01 & $4.8628 E+00$ & $6.2930 \mathrm{E}+00$ & $5.5931 \mathrm{E}-02$ \\
\hline $2.000 \mathrm{E}+01$ & $6.077 \mathrm{E}-01$ & $4.7655 E+00$ & $6.1672 \mathrm{E}+00$ & 1.0962E-01 \\
\hline $5.000 \mathrm{E}+01$ & $1.519 E+00$ & $4.4739 \mathrm{E}+00$ & $5.7897 \mathrm{E}+00$ & 2.5729E-01 \\
\hline $1.000 \mathrm{E}+02$ & $3.038 \mathrm{E}+00$ & $3.9877 E+00$ & $5.1606 \mathrm{E}+00$ & $4.5866 \mathrm{E}-01$ \\
\hline $2.000 \mathrm{E}+02$ & $6.077 \mathrm{E}+00$ & $2.6144 \mathrm{E}+00$ & $3.3833 E+00$ & $6.0140 \mathrm{E}-01$ \\
\hline $3.000 \mathrm{E}+02$ & $9.115 E+00$ & $2.0092 E+00$ & $2.6001 E+00$ & $6.9328 \mathrm{E}-01$ \\
\hline $5.0 \mathrm{COE}+02$ & $1.519 \mathrm{E}+01$ & $1.3734 \mathrm{E}+00$ & $1.7773 E+00$ & $7.8980 \mathrm{E}-01$ \\
\hline $7.000 E+02$ & $2.127 \mathrm{E}+01$ & $1.0432 \mathrm{E}+00$ & $1.3500 \mathrm{E}+00$ & 8.3992E-01 \\
\hline $1.000 \mathrm{E}+03$ & $3.038 \mathrm{E}+01$ & 7.6674E-01 & 9.9225E-01 & $8.8190 \mathrm{E}-01$ \\
\hline $1.500 \mathrm{E}+03$ & $4.558 \mathrm{E}+01$ & 5.3183E-01 & $6.8825 \mathrm{E}-01$ & $9.1756 \mathrm{E}-01$ \\
\hline $2.000 \mathrm{E}+03$ & $6.077 \mathrm{E}+01$ & 4.0711E-01 & 5.2684E-01 & 9.3649E-01 \\
\hline
\end{tabular}


Table A.3 (continued)

\begin{tabular}{|c|c|c|c|c|}
\hline \multicolumn{5}{|c|}{$\mathrm{UO}_{2} \mathrm{~F}_{2}-\mathrm{H}_{2} \mathrm{O}$} \\
\hline $\mathrm{H} / \mathrm{X}$ & $\mathrm{H} / \mathrm{U}$ & U den. & $\mathrm{UO}_{2} \mathrm{~F}_{2}$ den. & $\mathrm{H}_{2} \mathrm{O}$ den. \\
\hline \multicolumn{5}{|c|}{$2.0 \mathrm{E}+00 \%$ Enriched } \\
\hline $5.000 \mathrm{E}+00$ & $1.013 \mathrm{E}-01$ & $4.9276 \mathrm{E}+00$ & $6.3767 E+00$ & $1.8890 \mathrm{E}-02$ \\
\hline $1.000 \mathrm{E}+01$ & $2.026 \mathrm{E}-01$ & $4.8952 E+00$ & $6.3347 \mathrm{E}+00$ & 3.7531E-02 \\
\hline $2.000 \mathrm{E}+01$ & 4.051E-01 & $4.8304 \mathrm{E}+00$ & $6.2509 E+00$ & $7.4068 \mathrm{E}-02$ \\
\hline $5.000 \mathrm{E}+01$ & $1.013 \mathrm{E}+00$ & $4.6359 E+00$ & $5.9992 E+00$ & 1.7772E-01 \\
\hline $1.000 \mathrm{E}+02$ & $2.026 \mathrm{E}+00$ & $4.3118 \mathrm{E}+00$ & $5.5798 E+00$ & 3.3058E-01 \\
\hline $2.000 \mathrm{E}+02$ & $4.051 \mathrm{E}+00$ & $3.2717 \mathrm{E}+00$ & $4.2338 E+00$ & 5.0167E-01 \\
\hline $3.000 \mathrm{E}+02$ & $6.077 \mathrm{E}+00$ & $2.6147 E+00$ & $3.3836 \mathrm{E}+00$ & $6.0140 \mathrm{E}-01$ \\
\hline $5.000 \mathrm{E}+02$ & $1.013 \mathrm{E}+01$ & $1.8655 \mathrm{E}+00$ & $2.4141 \mathrm{E}+00$ & 7.1513E-01 \\
\hline $7.000 \mathrm{E}+02$ & $1.418 \mathrm{E}+01$ & $1.4500 \mathrm{E}+00$ & $1.8764 \mathrm{E}+00$ & $7.7819 \mathrm{E}-01$ \\
\hline $1.000 \mathrm{E}+03$ & $2.026 \mathrm{E}+01$ & $1.0869 \mathrm{E}+00$ & $1.4065 \mathrm{E}+00$ & 8.3331E-01 \\
\hline $1.500 \mathrm{E}+03$ & $3.038 \mathrm{E}+01$ & $7.6684 \mathrm{E}-01$ & 9.9235E-01 & 8.8190E-01 \\
\hline $2.000 \mathrm{E}+03$ & $4.051 E+01$ & $5.9240 \mathrm{E}-01$ & $7.6661 \mathrm{E}-01$ & $9.0838 \mathrm{E}-01$ \\
\hline \multicolumn{5}{|c|}{$1.7 \mathrm{E}+00 \%$ Enriched } \\
\hline $5.000 \mathrm{E}+00$ & 8.609E-02 & $4.9325 E+00$ & $6.3829 E+00$ & $1.6071 \mathrm{E}-02$ \\
\hline $1.000 \mathrm{E}+01$ & $1.722 \mathrm{E}-01$ & $4.9049 \mathrm{E}+00$ & $6.3473 E+00$ & 3.1963E-02 \\
\hline $2.000 \mathrm{E}+01$ & 3.443E-01 & $4.8498 \mathrm{E}+00$ & $6.2760 \mathrm{E}+00$ & $6.3209 \mathrm{E}-02$ \\
\hline $5.000 \mathrm{E}+01$ & 8.609E-01 & $4.6845 \mathrm{E}+00$ & $6.0621 E+00$ & $1.5264 \mathrm{E}-01$ \\
\hline $1.000 \mathrm{E}+02$ & $1.722 E+00$ & $4.4090 \mathrm{E}+00$ & $5.7056 \mathrm{E}+00$ & 2.8732E-01 \\
\hline $2.000 \mathrm{E}+02$ & $3.443 E+00$ & $3.8581 \mathrm{E}+00$ & $4.9926 \mathrm{E}+00$ & $5.0283 \mathrm{E}-01$ \\
\hline $3.000 \mathrm{E}+02$ & $5.165 \mathrm{E}+00$ & $2.8746 \mathrm{E}+00$ & $3.7199 \mathrm{E}+00$ & 5.6197E-01 \\
\hline $5.000 \mathrm{E}+02$ & $8.609 E+00$ & $2.0901 \mathrm{E}+00$ & $2.7048 \mathrm{E}+00$ & $6.8103 \mathrm{E}-01$ \\
\hline $7.000 \mathrm{E}+02$ & $1.205 \mathrm{E}+01$ & $1.6421 \mathrm{E}+00$ & $2.1249 E+00$ & $7.4905 \mathrm{E}-01$ \\
\hline $1.000 \mathrm{E}+03$ & $1.722 \mathrm{E}+01$ & $1.2425 \mathrm{E}+00$ & $1.6079 \mathrm{E}+00$ & 8.0970E-01 \\
\hline $1.500 \mathrm{E}+03$ & $2.583 \mathrm{E}+01$ & 8.8401E-01 & $1.1440 \mathrm{E}+00$ & 8.6411E-01 \\
\hline $2.000 \mathrm{E}+03$ & $3.443 E+01$ & $6.8606 \mathrm{E}-01$ & $8.8781 \mathrm{E}-01$ & 8.9416E-01 \\
\hline \multicolumn{5}{|c|}{$1.4 \mathrm{E}+00 \%$ Enriched } \\
\hline $5.000 \mathrm{E}+00$ & $7.090 \mathrm{E}-02$ & $4.9373 E+00$ & $6.3891 E+00$ & $1.3248 \mathrm{E}-02$ \\
\hline $1.000 \mathrm{E}+01$ & $1.418 \mathrm{E}-01$ & $4.9146 \mathrm{E}+00$ & $6.3598 \mathrm{E}+00$ & $2.6374 \mathrm{E}-02$ \\
\hline $2.000 \mathrm{E}+01$ & 2.836E-01 & $4.8693 E+00$ & $6.3011 \mathrm{E}+00$ & $5.2261 \mathrm{E}-02$ \\
\hline $5.000 \mathrm{E}+01$ & $7.090 \mathrm{E}-01$ & $4.7331 E+00$ & $6.1249 E+00$ & $1.2700 \mathrm{E}-01$ \\
\hline $1.000 \mathrm{E}+02$ & $1.418 \mathrm{E}+00$ & $4.5063 \mathrm{E}+00$ & $5.8314 \mathrm{E}+00$ & 2.4183E-01 \\
\hline $2.000 \mathrm{E}+02$ & $2.836 \mathrm{E}+00$ & $4.0525 \mathrm{E}+00$ & $5.2442 E+00$ & 4.3495E-01 \\
\hline $3.000 \mathrm{E}+02$ & $4.254 \mathrm{E}+00$ & $3.1917 \mathrm{E}+00$ & $4.1303 E+00$ & $5.1384 \mathrm{E}-01$ \\
\hline $5.000 \mathrm{E}+02$ & $7.090 \mathrm{E}+00$ & $2.3763 E+00$ & $3.0751 \mathrm{E}+00$ & $6.3761 \mathrm{E}-01$ \\
\hline $7.000 \mathrm{E}+02$ & $\therefore 925 \mathrm{E}+00$ & $1.8927 \mathrm{E}+00$ & $2.4493 E+00$ & 7.1101E-01 \\
\hline $1.000 \mathrm{E}+03$ & $1.418 \mathrm{E}+01$ & $1.4501 \mathrm{E}+00$ & $1.8765 E+00$ & 7.7819E-01 \\
\hline $1.500 \mathrm{E}+03$ & $2.127 E+01$ & $1.0434 \mathrm{E}+00$ & $1.3503 E+00$ & 8.3992E-01 \\
\hline $2.000 E+03$ & $2.836 \mathrm{E}+01$ & 8.1489E-01 & $1.0545 E+00$ & $8.7461 \mathrm{E}-01$ \\
\hline
\end{tabular}


Table A.4. Physical properties of $\mathrm{UF}_{6}$-HF systems

\begin{tabular}{|c|c|c|c|c|}
\hline \multicolumn{5}{|c|}{$\mathrm{UF}_{6}-\mathrm{HF}$} \\
\hline $\mathrm{H} / \mathrm{X}$ & $\mathrm{H} / \mathrm{U}$ & $\mathrm{U}$ den. & $\mathrm{UF}_{6}$ den. & HF den. \\
\hline \multicolumn{5}{|c|}{$5.0 \mathrm{E}+00 \%$ Enriched } \\
\hline $5.000 \mathrm{E}+00$ & 2.532E-01 & $3.1959 \mathrm{E}+00$ & $4.7273 E+00$ & 6.8051E-02 \\
\hline $1.000 \mathrm{E}+01$ & 5.064E-01 & $2.9840 \mathrm{E}+00$ & $4.4138 E+00$ & $1.2707 \mathrm{E}-01$ \\
\hline $2.000 \mathrm{E}+01$ & $1.013 E+00$ & $2.6345 E+00$ & $3.8969 E+00$ & $2.2439 \mathrm{E}-01$ \\
\hline $5.000 \mathrm{E}+01$ & $2.532 \mathrm{E}+00$ & $1.9496 \mathrm{E}+00$ & $2.8837 E+00$ & 4.1512E-01 \\
\hline $1.000 \mathrm{E}+02$ & $5.064 \mathrm{E}+00$ & $1.3602 \mathrm{E}+00$ & $2.0119 E+00$ & 5.7924E-01 \\
\hline $2.000 \mathrm{E}+02$ & $1.013 \mathrm{E}+01$ & 8.4765E-01 & $1.2538 \mathrm{E}+00$ & $7.2196 \mathrm{E}-01$ \\
\hline $3.000 E+02$ & $1.519 E+01$ & $6.1567 \mathrm{E}-01$ & 9.1067E-01 & $7.8656 \mathrm{E}-01$ \\
\hline $5.000 \mathrm{E}+02$ & $2.532 \mathrm{E}+01$ & $3.9788 \mathrm{E}-01$ & 5.8853E-01 & $8.4720 \mathrm{E}-01$ \\
\hline $7.000 \mathrm{E}+02$ & $3.545 E+01$ & 2.9391E-01 & 4.3474E-01 & 8.7616E-01 \\
\hline $1.000 \mathrm{E}+03$ & $5.064 \mathrm{E}+01$ & 2.1115E-01 & 3.1232E-01 & $8.9920 \mathrm{E}-01$ \\
\hline $1.500 \mathrm{E}+03$ & $7.596 \mathrm{E}+01$ & 1.4371E-01 & 2.1257E-01 & 9.1798E-01 \\
\hline $2.000 \mathrm{E}+62$ & $1.013 E+02$ & $1.0892 \mathrm{E}-01$ & $1.6111 \mathrm{E}-01$ & $9.2767 \mathrm{E}-01$ \\
\hline \multicolumn{5}{|c|}{$4.0 \mathrm{E}+09 \%$ Enriched } \\
\hline $5.000 \mathrm{E}+00$ & $2.026 \mathrm{E}-01$ & $3.2424 \mathrm{E}+00$ & $4.7958 E+00$ & 5.5225E-02 \\
\hline $1.000 \mathrm{E}+01$ & $4.051 \mathrm{E}-01$ & $3.0657 \mathrm{E}+00$ & $4.5344 \mathrm{E}+00$ & $1.0443 \mathrm{E}-01$ \\
\hline $2.000 E+01$ & 8.102E-01 & $2.7643 E+00$ & $4.0887 E+00$ & 1.8833E-01 \\
\hline $5.000 \mathrm{E}+01$ & $2.026 \mathrm{E}+00$ & $2.1348 E+00$ & $3.1576 \mathrm{E}+00$ & 3.6361E-01 \\
\hline $1.000 \mathrm{E}+02$ & $4.051 \mathrm{E}+00$ & $1.5475 \mathrm{E}+00$ & $2.2889 \mathrm{E}+00$ & $5.2714 \mathrm{E}-01$ \\
\hline $2.000 \mathrm{E}+02$ & $8.102 E+00$ & 9.9822E-01 & $1.4765 E+00$ & 6.8007E-01 \\
\hline $3.000 \mathrm{E}+02$ & $1.215 E+01$ & 7.3672E-01 & $1.0897 E+00$ & 7.5288E-01 \\
\hline $5.000 \mathrm{E}+02$ & $2.026 \mathrm{E}+01$ & 4.8344E-01 & 7.1505E-01 & $8.2340 \mathrm{E}-01$ \\
\hline $7.000 \mathrm{E}+02$ & $2.836 \mathrm{E}+01$ & 3.5975E-01 & 5.3211E-01 & 8.5783E-01 \\
\hline $1.000 \mathrm{E}+03$ & $4.051 \mathrm{E}+01$ & 2.5998E-01 & 3.8454E-01 & 8.8561E-01 \\
\hline $1.500 \mathrm{E}+03$ & $6.077 \mathrm{E}+01$ & $1.7780 \mathrm{E}-01$ & 2.6298E-01 & $9.0850 \mathrm{E}-01$ \\
\hline $2.000 \mathrm{E}+03$ & $8.102 E+01$ & $1.3510 \mathrm{E}-01$ & $1.9982 \mathrm{E}-01$ & $9.2039 \mathrm{E}-01$ \\
\hline \multicolumn{5}{|c|}{$3.0 \mathrm{E}+00 \%$ Enriched } \\
\hline $5.000 E+00$ & 1.519E-01 & $3.2902 \mathrm{E}+00$ & $4.8664 \mathrm{E}+00$ & 4.2025E-02 \\
\hline $1.000 \mathrm{E}+01$ & 3.038E-01 & $3.1520 E+00$ & $4.6619 E+00$ & 8.0517E-02 \\
\hline $2.000 \mathrm{E}+01$ & 6.077E-01 & $2.9076 \mathrm{E}+00$ & $4.3004 E+00$ & $1.4855 \mathrm{E}-01$ \\
\hline $5.000 \mathrm{E}+01$ & $1.519 \mathrm{E}+00$ & $2.3589 E+00$ & $3.4889 E+00$ & 3.0129E-01 \\
\hline $1.000 \mathrm{E}+02$ & $3.038 \mathrm{E}+00$ & $1.7945 E+00$ & $2.6542 \mathrm{E}+00$ & 4.5841E-01 \\
\hline $2.000 \mathrm{E}+02$ & $6.077 E+00$ & $1.2137 \mathrm{E}+00$ & $1.7952 \mathrm{E}+00$ & $6.2010 \mathrm{E}-01$ \\
\hline $3.000 \mathrm{E}+02$ & $9.115 \mathrm{E}+00$ & 9.169;E-01 & $1.3562 \mathrm{E}+00$ & 7.0272E-01 \\
\hline $5.000 \mathrm{E}+02$ & $1.519 \mathrm{E}+01$ & 6.1582E-01 & 9.1082E-01 & 7.8656E-01 \\
\hline $7.000 \mathrm{E}+02$ & $2.127 E+01$ & 4.6358E-01 & $6.8565 \mathrm{E}-01$ & 8.2894E-01 \\
\hline $1.000 \mathrm{E}+03$ & $3.038 E+01$ & 3.3817E-01 & $5.0017 \mathrm{E}-01$ & 8.6386E-01 \\
\hline $1.500 \mathrm{E}+0.3$ & $4.558 \mathrm{E}+01$ & 2.3308E-01 & 3.4474E-01 & 8.9311E-01 \\
\hline $2.000 \mathrm{E}+03$ & $6.077 \mathrm{E}+01$ & $1.7782 \mathrm{E}-01$ & 2.6301E-01 & $9.0850 \mathrm{E}-01$ \\
\hline
\end{tabular}


Table A.4 (continued)

\begin{tabular}{|c|c|c|c|c|}
\hline \multicolumn{5}{|c|}{$\mathrm{UF}_{6}-\mathrm{HF}$} \\
\hline $\mathrm{H} / \mathrm{X}$ & $\mathrm{H} / \mathrm{U}$ & U den. & $\mathrm{UF}_{6}$ den. & HF den. \\
\hline \multicolumn{5}{|c|}{$2.0 \mathrm{E}+00 \%$ Enriched } \\
\hline $5.000 \mathrm{E}+00$ & $1.013 E-01$ & $3.3395 E+00$ & $4.9390 E+00$ & $2.8432 \mathrm{E}-02$ \\
\hline $1.000 \mathrm{E}+01$ & $2.026 \mathrm{E}-01$ & $3.2432 \mathrm{E}+00$ & $4.7967 \mathrm{E}+00$ & $5.5225 \mathrm{E}-02$ \\
\hline $2.000 \mathrm{E}+01$ & 4.051E-01 & $3.0665 E+00$ & $4.5352 \mathrm{E}+00$ & $1.0443 \mathrm{E}-01$ \\
\hline $5.000 \mathrm{E}+01$ & $1.013 E+00$ & $2.6355 E+00$ & $3.8979 E+00$ & 2.2439E-01 \\
\hline $1.000 \mathrm{E}+02$ & $2.026 \mathrm{E}+00$ & $2.1354 \mathrm{E}+00$ & $3.1582 \mathrm{E}+00$ & 3.6361E-01 \\
\hline $2.000 \mathrm{E}+02$ & $4.051 E+00$ & $1.5479 E+00$ & $2.2893 E+00$ & $5.2714 \mathrm{E}-01$ \\
\hline $3.000 \mathrm{E}+02$ & $6.077 \mathrm{E}+00$ & $1.2139 \mathrm{E}+00$ & $1.7953 E+00$ & $6.2010 \mathrm{E}-01$ \\
\hline $5.000 \mathrm{E}+02$ & $1.013 \mathrm{E}+01$ & 8.4798E-01 & $1.2541 \mathrm{E}+00$ & $7.2196 \mathrm{E}-01$ \\
\hline $7.000 \mathrm{E}+02$ & $1.418 \mathrm{E}+01$ & 6.5157E-01 & 9.6365E-01 & 7.7663E-01 \\
\hline $1.000 \mathrm{E}+03$ & $2.026 \mathrm{E}+01$ & 4.8356E-01 & 7.1517E-01 & $8.2340 \mathrm{E}-01$ \\
\hline $1.500 \mathrm{E}+03$ & $3.038 \mathrm{E}+01$ & 3.3821E-01 & $5.0021 \mathrm{E}-01$ & 8.6386E-01 \\
\hline $2.000 \mathrm{E}+03$ & $4.051 E+01$ & 2.6005E-01 & 3.8461E-01 & 8.8561E-01 \\
\hline \multicolumn{5}{|c|}{ 1.7E+00 \% Enriched } \\
\hline $5.000 \mathrm{E}+00$ & 8.609E-02 & $3.3546 \mathrm{E}+00$ & $4.9612 E+00$ & $2.4275 \mathrm{E}-02$ \\
\hline $1.000 \mathrm{E}+01$ & $1.722 \mathrm{E}-01$ & $3.2717 \mathrm{E}+00$ & $4.8386 \mathrm{E}+00$ & 4.7351E-02 \\
\hline $2.000 \mathrm{E}+01$ & 3.443E-01 & $3.1176 \mathrm{E}+00$ & $4.6107 E+00$ & 9.0241E-02 \\
\hline $5.000 \mathrm{E}+01$ & 8.609E-01 & $2.7316 \mathrm{E}+00$ & $4.0399 E+00$ & 1.9767E-01 \\
\hline $1.000 \mathrm{E}+02$ & $1.722 E+00$ & $2.2644 \mathrm{E}+00$ & $3.3489 \mathrm{E}+00$ & 3.2772E-01 \\
\hline $2.000 \mathrm{E}+02$ & $3.443 E+00$ & $1.6872 E+00$ & $2.4953 E+00$ & 4.8838E-01 \\
\hline $3.000 \mathrm{E}+02$ & $5.165 \mathrm{E}+00$ & $1.3445 \mathrm{E}+00$ & $1.9884 \mathrm{E}+00$ & $5.8377 \mathrm{E}-01$ \\
\hline $5.000 \mathrm{E}+02$ & $8.609 E+00$ & 9.5609E-01 & $1.4140 \mathrm{E}+00$ & $6.9188 \mathrm{E}-01$ \\
\hline $7.000 E+02$ & $1.205 E+01$ & $7.4180 \mathrm{E}-01$ & $1.0971 \mathrm{E}+00$ & 7.5152E-01 \\
\hline $1.000 \mathrm{E}+03$ & $1.722 \mathrm{E}+01$ & $5.5515 \mathrm{E}-01$ & 8.2104E-01 & 8.0348E-01 \\
\hline $1.500 \mathrm{E}+03$ & $2.583 E+01$ & 3.9113E-01 & $5.7846 \mathrm{E}-01$ & 8.4913E-01 \\
\hline $2.000 \mathrm{E}+03$ & $3.443 E+01$ & 3.0193E-01 & 4.4653E-01 & $8.7396 \mathrm{E}-01$ \\
\hline \multicolumn{5}{|c|}{$1.4 \mathrm{E}+00 \%$ Enriched } \\
\hline $5.000 \mathrm{E}+00$ & $7.090 \mathrm{E}-02$ & $3.3698 \mathrm{E}+00$ & $4.9836 \mathrm{E}+00$ & $2.0081 \mathrm{E}-02$ \\
\hline $1.000 \mathrm{E}+01$ & $1.418 \mathrm{E}-01$ & $3.3006 \mathrm{E}+00$ & $4.8813 E+00$ & $3.9338 \mathrm{E}-02$ \\
\hline $2.000 \mathrm{E}+01$ & $2.836 \mathrm{E}-01$ & $3.1704 E+00$ & $4.6888 \mathrm{E}+00$ & 7.5573E-02 \\
\hline $5.000 \mathrm{E}+01$ & $7.090 \mathrm{E}-01$ & $2.8349 \mathrm{E}+00$ & $4.1927 \mathrm{E}+00$ & $1.6894 \mathrm{E}-01$ \\
\hline $1.000 E+02$ & $1.418 \mathrm{E}+00$ & $2.4099 E+00$ & $3.5641 \mathrm{E}+00$ & 2.8723E-01 \\
\hline $2.000 E+02$ & $2.836 \mathrm{E}+00$ & $1.8541 \mathrm{E}+00$ & $2.7420 \mathrm{E}+00$ & 4.4195E-01 \\
\hline $3.000 \mathrm{E}+02$ & $4.254 \mathrm{E}+00$ & $1.5065 \mathrm{E}+00$ & $2.2281 \mathrm{E}+00$ & $5.3868 \mathrm{E}-01$ \\
\hline $5.000 \mathrm{E}+02$ & $7.090 \mathrm{E}+00$ & $1.0958 \mathrm{E}+00$ & $1.6206 \mathrm{E}+00$ & 6.5301E-01 \\
\hline $7.000 \mathrm{E}+02$ & $9.925 E+00$ & 8.6102E-01 & $1.2734 \mathrm{E}+00$ & $7.1835 \mathrm{E}-01$ \\
\hline $1.000 \mathrm{E}+03$ & $1.418 \mathrm{E}+01$ & $6.5162 \mathrm{E}-01$ & 9.6370E-01 & 7.7663E-01 \\
\hline $1.500 \mathrm{E}+03$ & $2.127 E+01$ & 4.6367E-01 & $6.8574 \mathrm{E}-01$ & 8.2894E-01 \\
\hline $2.000 \mathrm{E}+03$ & $2.836 \mathrm{E}+01$ & $3.5987 \mathrm{E}-01$ & 5.3223E-01 & 8.5783E-01 \\
\hline
\end{tabular}




\section{APPENDIX B \\ TABLES OF CALCULATED VALUES FOR SECTION 2}

Tables B.1 and B.2 give the calculated infinite media multiplication values predicted using SCALE-4 and the SCALE 27-group ENDF/B-IV cross-section library for each system listed in Tables A.3 and A.4. The CSAS1X control sequence prepares input data and executes BONAMI, NITAWL, and XSDRNPM.

Tables B.3 and B.4 list critical parameters at each enrichment and several $\mathrm{H} / \mathrm{X}$ moderation ratios predicted using XSDRNPM and the 27-group ENDF/B-IV cross-section library in SCALE-4. 
60

Tatle B.1. $\mathrm{k}_{\infty}$ for $\mathrm{UO}_{2} \mathrm{~F}_{2}-\mathrm{H}_{2} \mathrm{O}$ systems using the SCALE 27-group library

\begin{tabular}{lllllll}
\hline & \multicolumn{5}{c}{ \% Enrichment } \\
\cline { 2 - 7 } $\mathrm{H} / \mathrm{X}$ & 5.0 & 4.0 & 3.0 & 2.0 & 1.7 & 1.4 \\
\hline & & & & & & \\
$5.000 \mathrm{E}+00$ & $8.81333-1$ & $7.93512-1$ & $6.87041-1$ & $5.55748-1$ & $5.10421-1$ & $4.62036-1$ \\
$1.000 \mathrm{E}+01$ & $9.63163-1$ & $8.73875-1$ & $7.60571-1$ & $6.13581-1$ & $5.60951-1$ & $5.03967-1$ \\
$2.000 \mathrm{E}+01$ & 1.08401 & $9.96199-1$ & $8.79551-1$ & $7.16552-1$ & $6.54776-1$ & $5.85342-1$ \\
$5.000 \mathrm{E}+01$ & 1.27189 & 1.19358 & 1.08394 & $9.16725-1$ & $8.47631-1$ & $7.65433-1$ \\
$1.000 \mathrm{E}+02$ & 1.38902 & 1.32164 & 1.22466 & 1.07018 & 1.00338 & $9.20974-1$ \\
$2.000 \mathrm{E}+02$ & 1.44607 & 1.39075 & 1.30964 & 1.17623 & 1.11675 & 1.04172 \\
$3.000 \mathrm{E}+02$ & 1.44016 & 1.39206 & 1.32102 & 1.20227 & 1.14849 & 1.07998 \\
$5.000 \mathrm{E}+02$ & 1.38267 & 1.34382 & 1.28586 & 1.18737 & 1.14215 & 1.08382 \\
$7.000 \mathrm{E}+02$ & 1.31182 & 1.27903 & 1.22992 & 1.14571 & 1.10666 & 1.05588 \\
$1.000 \mathrm{E}+03$ & 1.20866 & 1.18222 & 1.14238 & 1.07355 & 1.04134 & $9.99196-1$ \\
$1.500 \mathrm{E}+03$ & 1.06147 & 1.04178 & 1.01201 & $9.60152-1$ & $9.35683-1$ & $9.03401-1$ \\
$2.000 \mathrm{E}+03$ & $9.43632-1$ & $9.28235-1$ & $9.04946-1$ & $8.64176-1$ & $8.44828-1$ & $8.19175-1$ \\
& & & & & & \\
\hline
\end{tabular}

Table B.2. $\mathrm{k}_{\infty}$ for $\mathrm{UF}_{6}-\mathrm{HF}$ systems using the SCALE 27-group library

\begin{tabular}{lllllll}
\hline & \multicolumn{5}{c}{ \% Enrichment } \\
\cline { 2 - 7 } $\mathrm{H} / \mathrm{X}$ & 5.0 & 4.0 & 3.0 & 2.0 & 1.7 & 1.4 \\
\hline & & & & & & \\
$5.000 \mathrm{E}+00$ & $8.19499-1$ & $7.32459-1$ & $6.27232-1$ & $4.98597-1$ & $4.54192-1$ & $4.06768-1$ \\
$1.000 \mathrm{E}+01$ & $9.05968-1$ & $8.15744-1$ & $7.02198-1$ & $5.56021-1$ & $5.04333-1$ & $4.48155-1$ \\
$2.000 \mathrm{E}+01$ & 1.03490 & $9.44869-1$ & $8.25771-1$ & $6.60869-1$ & $5.99098-1$ & $5.29825-1$ \\
$5.000 \mathrm{E}+01$ & 1.23487 & 1.15383 & 1.04069 & $8.68930-1$ & $7.98222-1$ & $7.14412-1$ \\
$1.000 \mathrm{E}+02$ & 1.35879 & 1.28932 & 1.18946 & 1.03050 & $9.61796-1$ & $8.77323-1$ \\
$2.000 \mathrm{E}+02$ & 1.41973 & 1.36315 & 1.28013 & 1.14342 & 1.08243 & 1.00551 \\
$3.000 \mathrm{E}+02$ & 1.41511 & 1.36606 & 1.29357 & 1.17236 & 1.11749 & 1.04753 \\
$5.000 \mathrm{E}+02$ & 1.35838 & 1.31893 & 1.26010 & 1.16015 & 1.11419 & 1.05488 \\
$7.000 \mathrm{E}+02$ & 1.28783 & 1.25467 & 1.20497 & 1.11975 & 1.08021 & 1.02881 \\
$1.000 \mathrm{E}+03$ & 1.18510 & 1.15841 & 1.11825 & 1.04883 & 1.01633 & $9.73798-1$ \\
$1.500 \mathrm{E}+03$ & 1.03887 & 1.01903 & $9.89123-1$ & $9.37008-1$ & $9.12395-1$ & $8.79951-1$ \\
$2.000 \mathrm{E}+03$ & $9.22151-1$ & $9.06687-1$ & $8.83307-1$ & $8.42411-1$ & $8.22988-1$ & $7.97281-1$ \\
\hline
\end{tabular}


61

Table B.3. Critical parameters for $\mathrm{UO}_{2} \mathrm{~F}_{2}-\mathrm{H}_{2} \mathrm{O}$ using the SCALE 27-group library

\begin{tabular}{|c|c|c|c|c|c|}
\hline Enrichment & $\mathrm{H} / \mathrm{X}$ & $\begin{array}{c}\text { Critical radius } \\
(\mathrm{cm})\end{array}$ & $\begin{array}{l}\text { Critical volume } \\
\text { (I) }\end{array}$ & $\begin{array}{c}\text { Critical mass } \\
(\mathrm{kg} \mathrm{U})\end{array}$ & $\mathrm{H}_{2} \mathrm{O} \mathrm{kg}$ \\
\hline \multirow[t]{5}{*}{5.0} & 100 & 22.078 & 45.078 & 130.970 & 25.113 \\
\hline & 200 & 19.621 & 31.641 & 59.004 & 22.627 \\
\hline & 300 & 19.705 & 32.049 & 44.003 & 25.312 \\
\hline & 500 & 21.423 & 41.184 & 37.020 & 35.492 \\
\hline & 700 & 24.384 & 60.730 & 40.578 & 54.464 \\
\hline \multirow[t]{5}{*}{4.0} & 100 & 25.478 & 69.276 & 226.588 & 34.754 \\
\hline & 200 & 21.696 & 42.779 & 93.126 & 28.567 \\
\hline & 300 & 21.384 & 40.960 & 66.818 & 30.745 \\
\hline & 500 & 23.020 & 51.098 & 55.523 & 42.580 \\
\hline & 700 & 26.233 & 75.619 & 61.601 & 66.137 \\
\hline \multirow[t]{5}{*}{3.0} & 100 & 30.860 & 123.105 & 490.906 & 56.463 \\
\hline & 200 & 25.709 & 71.178 & 186.088 & 42.806 \\
\hline & 300 & 24.660 & 62.816 & 126.210 & 43.549 \\
\hline & 500 & 26.125 & 74.689 & 102.578 & 58.989 \\
\hline & 700 & 29.608 & 108.722 & 113.419 & 91.318 \\
\hline \multirow[t]{5}{*}{2.0} & 100 & 68.944 & 1372.708 & 5918.842 & 453.790 \\
\hline & 200 & 37.622 & 223.056 & 729.772 & 111.901 \\
\hline & 300 & 33.551 & 158.199 & 413.643 & 95.141 \\
\hline & 500 & 34.222 & 167.882 & 313.184 & 120.057 \\
\hline & 700 & 39.136 & 251.083 & 364.070 & 195.390 \\
\hline \multirow[t]{4}{*}{1.7} & 200 & 44.494 & 368.972 & 1423.531 & 185.530 \\
\hline & 300 & 40.725 & 282.925 & 813.296 & 158.995 \\
\hline & 500 & 40.492 & 278.097 & 581.251 & 189.392 \\
\hline & 700 & 47.253 & 441.954 & 725.733 & 331.046 \\
\hline \multirow[t]{4}{*}{1.4} & 200 & 83.483 & 2437.153 & 9876.563 & 1060.040 \\
\hline & 300 & 59.670 & 889.932 & 2840.396 & 457.283 \\
\hline & 500 & 55.461 & 714.581 & 1698.059 & 455.624 \\
\hline & 700 & 68.124 & 1324.308 & 2506.518 & 941.569 \\
\hline
\end{tabular}


Table B.4. Critical parameters for $\mathrm{UF}_{6}-\mathrm{HF}$ using the SCALE 27-group library

\begin{tabular}{|c|c|c|c|c|c|}
\hline Enrichment & $\mathrm{H} / \mathrm{X}$ & $\begin{array}{l}\text { Critical radius } \\
(\mathrm{cm})\end{array}$ & $\begin{array}{l}\text { Critical volume } \\
\text { (l) }\end{array}$ & $\begin{array}{c}\text { Critical mass } \\
(\mathrm{kg} \mathrm{U})\end{array}$ & $\mathrm{HF} \mathrm{kg}$ \\
\hline \multirow[t]{5}{*}{5.0} & 100 & 39.110 & 250.583 & 340.843 & 145.148 \\
\hline & 200 & 35.663 & 189.995 & 161.049 & 137.169 \\
\hline & 300 & 36.331 & 200.873 & 123.476 & 157.749 \\
\hline & 500 & 40.611 & 280.556 & 111.628 & 237.687 \\
\hline & 700 & 47.171 & 439.657 & 129.220 & 385.210 \\
\hline \multirow[t]{5}{*}{4.0} & 100 & 45.456 & 393.425 & 608.825 & 207.390 \\
\hline & 200 & 39.366 & 255.536 & 255.081 & 173.782 \\
\hline & 300 & 39.538 & 258.900 & 190.737 & 194.921 \\
\hline & 500 & 43.763 & 351.083 & 169.728 & 289.082 \\
\hline & 700 & 50.552 & 541.133 & 194.673 & 464.200 \\
\hline \multirow[t]{5}{*}{3.0} & 100 & 59.984 & 904.055 & 1622.327 & 414.428 \\
\hline & 200 & 46.900 & 432.123 & 524.468 & 267.959 \\
\hline & 300 & 45.667 & 398.929 & 365.806 & 280.335 \\
\hline & 500 & 49.565 & 510.051 & 314.100 & 401.186 \\
\hline & 700 & 57.337 & 789.575 & 366.031 & 654.510 \\
\hline \multirow[t]{4}{*}{2.0} & 200 & 71.473 & 1529.377 & 2367.323 & 806.196 \\
\hline & 300 & 63.723 & 1083.870 & 1315.710 & 672.108 \\
\hline & 500 & 66.185 & 1214.416 & 1029.800 & 876.760 \\
\hline & 700 & 78.155 & 1999.673 & 1302.927 & 1553.006 \\
\hline \multirow[t]{4}{*}{1.7} & 200 & 98.741 & 4032.563 & 6803.740 & 1969.423 \\
\hline & 300 & 79.674 & 2118.549 & 2848.348 & 1236.745 \\
\hline & 500 & 80.837 & 2212.683 & 2115.524 & 1530.911 \\
\hline & 700 & 98.213 & 3968.218 & 2943.624 & 2982.195 \\
\hline \multirow[t]{4}{*}{1.4} & 200 & 575.878 & 799981.737 & 1483246.139 & 353551.929 \\
\hline & 300 & 133.151 & 9888.306 & 14896.733 & 5326.633 \\
\hline & 500 & 123.624 & 7914.017 & 8672.180 & 5167.932 \\
\hline & 700 & 183.862 & 26035.418 & 22417.016 & 18702.543 \\
\hline
\end{tabular}




\section{APPENDIX C \\ RESULTS OF THE 1983 MINIMUM MODERATOR MASS STUDY}

This appendix contains tables of results from the 1983 minimum-mass study. These values were calculated using the ANISN cornputer code and the Knight-modified Hansen-Roach cross sections as distributed with KENO-IV.

Tables C.1 and C.2 give calculated infinite media multiplication factors. Tables C.3 and C.4 give calculated critical parameters.

Table C.1. $\mathrm{k}_{\infty}$ for $\mathrm{UO}_{2} \mathrm{~F}_{2}-\mathrm{H}_{2} \mathrm{O}$ systems using the Knight-modified Hansen-Roach cross sections

\begin{tabular}{rlllcc}
\hline $\mathrm{H} / \mathrm{X}$ & $5.0 \%$ & $3.0 \%$ & $2.0 \%$ & $1.7 \%$ & $1.4 \%$ \\
\hline 5 & 0.9596 & 0.75144 & $\ldots$ & $\ldots$ & $\ldots$ \\
10 & 1.01418 & 0.81097 & $\ldots-$. & $\ldots$ & $\ldots$ \\
20 & 1.13762 & 0.93385 & 0.76892 & 0.70014 & $\ldots$ \\
50 & 1.31498 & 1.13937 & 0.96895 & 0.90647 & 0.82472 \\
100 & 1.41953 & 1.26473 & 1.12249 & 1.05437 & 0.98281 \\
200 & 1.45713 & 1.33779 & 1.20778 & 1.16135 & 1.08281 \\
300 & 1.44752 & 1.33372 & 1.22991 & 1.17967 & 1.11475 \\
500 & 1.39738 & 1.29507 & 1.20037 & 1.16200 & 1.11031 \\
700 & 1.33602 & 1.23862 & 1.15981 & 1.11883 & 1.07671 \\
1000 & 1.23932 & 1.15913 & 1.08045 & 1.06095 & 1.01371 \\
1500 & 1.08818 & 1.03825 & 0.97231 & 0.95344 & 0.91448 \\
2000 & 0.974296 & 0.92476 &.-- & $\ldots$ & $\ldots$ \\
\hline
\end{tabular}


Table C.2. $k_{\infty} U_{6}-H F$ systems using the Knight-modified Hansen-Roach cross sections

\begin{tabular}{rrrccc}
\hline $\mathrm{H} / \mathrm{X}$ & $5.0 \%$ & $3.0 \%$ & $2.0 \%$ & $1.7 \%$ & $1.4 \%$ \\
\hline 5 & 0.93340 & 0.70650 & $\ldots--$ & $\ldots$ & $\ldots$ \\
10 & 0.97734 & 0.77054 & $\ldots--$ & $\ldots$ & $\ldots$ \\
20 & 1.05741 & 0.89957 & 0.73193 & 0.66329 & $\ldots-$ \\
50 & 1.27002 & 1.09127 & 0.91130 & 0.86840 & 0.77178 \\
100 & 1.38137 & 1.24161 & 1.07914 & 1.00864 & 0.93487 \\
200 & 1.43047 & 1.30376 & 1.17781 & 1.13043 & 1.04833 \\
300 & 1.42941 & 1.30419 & 1.19639 & 1.14176 & 1.08529 \\
500 & 1.36910 & 1.27605 & 1.17318 & 1.13194 & 1.07863 \\
700 & 1.30585 & 1.21392 & 1.13145 & 1.08849 & 1.04848 \\
1000 & 1.21809 & 1.13357 & 1.06076 & 1.02241 & 0.98644 \\
1500 & 1.06701 & 1.01770 & 0.95743 & 0.92775 & 0.89154 \\
2000 & 0.95356 &.-- & $\ldots$ & $\ldots$ & $\ldots$ \\
\hline
\end{tabular}


Table C.3. Critical parameters for $\mathrm{UO}_{2} \mathrm{~F}_{2}-\mathrm{H}_{2} \mathrm{O}$ using the Knight-modified Hansen-Roach cross sections

\begin{tabular}{|c|c|c|c|c|c|}
\hline $\begin{array}{c}\% \\
\text { Enrichment }\end{array}$ & $\mathrm{H} / \mathrm{X}$ & $\begin{array}{l}\text { Critical radius } \\
(\mathrm{cm})\end{array}$ & $\begin{array}{c}\text { Critical volume } \\
\text { (1) } \\
\end{array}$ & $\begin{array}{c}\text { Critical mass } \\
(\mathrm{kgU})\end{array}$ & $\begin{array}{l}\text { Moderator mass } \\
\left(\mathrm{kg} \mathrm{H} \mathrm{H}_{2} \mathrm{O}\right)\end{array}$ \\
\hline \multirow[t]{5}{*}{5.0} & 100 & 21.1 & 39.35 & 118.8 & 22.8 \\
\hline & 200 & 19.3 & 30.11 & 58.1 & 22.3 \\
\hline & 300 & 20.4 & 35.56 & 48.0 & 27.6 \\
\hline & 500 & 21.8 & 43.40 & 38.6 & 37.0 \\
\hline & 700 & 24.2 & 59.37 & 39.3 & 52.9 \\
\hline \multirow[t]{4}{*}{3.0} & 100 & 31.8351 & 135.147 & 494.463 & 56.849 \\
\hline & 200 & 24.1569 & 59.049 & 162.231 & 37.303 \\
\hline & 300 & 23.8979 & 57.170 & 119.891 & 41.351 \\
\hline & 500 & 26.8948 & 81.488 & 109.8865 & 63.169 \\
\hline \multirow[t]{4}{*}{2.0} & 100 & 56.8322 & 768.904 & 3100.06 & 237.598 \\
\hline & 200 & 35.2383 & 183.287 & 608.845 & 93.330 \\
\hline & 300 & 30.9211 & 123.8379 & 340.2074 & 78.226 \\
\hline & 500 & 33.0577 & 151.324 & 291.691 & 111.786 \\
\hline \multirow[t]{4}{*}{1.7} & 200 & 42.6778 & 325.608 & 1146.009 & 149.321 \\
\hline & 300 & 36.7800 & 208.413 & 623.195 & 121.802 \\
\hline & 500 & 37.4104 & 219.314 & 480.231 & 156.433 \\
\hline & 700 & 45.7854 & 402.040 & 667.508 & 304.410 \\
\hline \multirow[t]{4}{*}{1.4} & 200 & 66.3662 & 1224.417 & 4567.199 & 490.07 \\
\hline & 300 & 49.9523 & 522.1017 & 1701.268 & 273.827 \\
\hline & 500 & 47.3765 & 445.428 & 1115.530 & 299.250 \\
\hline & 700 & 58.1412 & 823.2668 & 1613.3559 & 553.092 \\
\hline
\end{tabular}


Table C.4. Critical parameters for $\mathrm{UF}_{6}-\mathrm{HF}$ systems using the Knight-modified Hansen-Roach cross sections

\begin{tabular}{lccccc}
\hline $\begin{array}{c}\% \\
\text { Enrichment }\end{array}$ & $\mathrm{H} / \mathrm{X}$ & $\begin{array}{c}\text { Critical radius } \\
(\mathrm{cm})\end{array}$ & $\begin{array}{c}\text { Critical volume } \\
(1)\end{array}$ & $\begin{array}{r}\text { Critical mass } \\
(\mathrm{kgU})\end{array}$ & $\begin{array}{c}\text { Moderator mass } \\
(\mathrm{kg} \mathrm{HF})\end{array}$ \\
\hline 5.0 & 100 & 34.1565 & 166.920 & 270.644 & 115.182 \\
& 200 & 30.8937 & 123.509 & 127.585 & 108.590 \\
& 300 & 30.9320 & 123.9689 & 93.956 & 119.956 \\
& 500 & 34.2626 & 168.481 & 83.314 & 177.292 \\
& 700 & 38.7159 & 243.084 & 89.2119 & 265.769 \\
3.0 & & & & & \\
& 100 & 48.3653 & 473.904 & 995.198 & 254.114 \\
& 200 & 40.0466 & 269.021 & 391.586 & 199.977 \\
& 300 & 39.3874 & 255.953 & 285.081 & 218.388 \\
2.0 & 500 & 41.6399 & 302.425 & 229.208 & 292.646 \\
& & & & & \\
& 200 & 57.8921 & 812.730 & 1487.297 & 506.365 \\
& 300 & 53.0730 & 626.195 & 911.489 & 465.504 \\
& 500 & 55.9314 & 732.919 & 757.105 & 644.412 \\
1.7 & 700 & 65.1432 & 157.966 & 926.952 & 1104.636 \\
& & & & & \\
& 200 & 70.7364 & 1482.578 & 2939.952 & 850.77 \\
& 300 & 65.3421 & 168.605 & 1873.508 & 813.255 \\
& 500 & 66.3236 & 222.061 & 1416.613 & 1024.882 \\
& 700 & 82.2357 & 329.538 & 2114.755 & 2141.931 \\
& & & & & \\
& & & & & \\
& 200 & 128.326 & 8851.820 & 19154.453 & 4565.05 \\
& 300 & 89.8978 & 043.237 & 5429.439 & 1940.946 \\
& 500 & 90.7661 & 132.273 & 4136.480 & 2464.470 \\
& 700 & 117.168 & 737.762 & 7062.522 & 5891.216 \\
\hline
\end{tabular}




\section{APPENDIX D}

\section{TABLES OF CALCULATED VALUES FOR SECTION 3.1}

This appendix contains tables of results used in Sect. 3.1 for cross-section comparisons. The CSAS1X control sequence of SCALE-4 was used to obtain calculated infinite media multiplication factors for selected systems.

Tables D.1 and D.2 give values of $k_{\infty}$ predicted using the SCALE 16-group library that is included in SCALE-4.

Tables D.3 and D.4 give values $k_{\infty}$ predicted using the LAW-238 ENDF/B-V fine-group library generated at ORNL. This library is not part of SCALE and was used as an independent reference.

Table D.1. $\mathrm{k}_{\infty}$ for $\mathrm{UO}_{2} \mathrm{~F}_{2}-\mathrm{H}_{2} \mathrm{O}$ systems using the SCALE 16-group library

\begin{tabular}{cllllll}
\hline $\mathrm{H} / \mathrm{X}$ & $5.0 \%$ & $4.0 \%$ & $3.0 \%$ & $2.0 \%$ & $1.7 \%$ & $1.4 \%$ \\
\hline 5 & 0.934757 & 0.848083 & 0.742242 & 0.608830 & 0.561554 & 0.510214 \\
10 & 1.00741 & 0.918760 & 0.806853 & 0.660984 & 0.608319 & 0.5540329 \\
20 & 1.12277 & 1.03860 & 0.924300 & 0.759448 & 0.697177 & 0.627266 \\
50 & 1.30100 & 1.22618 & 1.12624 & 0.963198 & 0.894538 & 0.812195 \\
100 & 1.40743 & 1.34749 & 1.25882 & 1.10972 & 1.04646 & 0.966783 \\
200 & 1.45203 & 1.40403 & 1.32935 & 1.20591 & 1.15315 & 1.07727 \\
300 & 1.43457 & 1.39620 & 1.33385 & 1.22408 & 1.17363 & 1.10979 \\
500 & 1.39039 & 1.34665 & 1.28691 & 1.20039 & 1.15961 & 1.10453 \\
700 & 1.32754 & 1.29103 & 1.23640 & 1.15321 & 1.11777 & 1.07062 \\
1000 & 1.23018 & 1.20132 & 1.15732 & 1.08121 & 1.04568 & 1.00856 \\
1500 & 1.08629 & 1.06537 & 1.03308 & 0.976061 & 0.949311 & 0.913548 \\
2000 & 0.968434 & 0.952739 & 0.927977 & 0.883590 & 0.862263 & 0.833990 \\
& & & & & & \\
\hline
\end{tabular}


68

Table D.2. $\mathbf{k}_{\infty}$ for $\mathrm{UF}_{6}-\mathrm{HF}$ systems using the

SCALE 16-group library

\begin{tabular}{cllllll}
\hline $\mathrm{H} / \mathrm{X}$ & $5.0 \%$ & $4.0 \%$ & $3.0 \%$ & $2.0 \%$ & $1.7 \%$ & $1.4 \%$ \\
\hline 5 & 0.883584 & 0.796980 & 0.690648 & 0.557223 & 0.510242 & 0.459340 \\
10 & 0.955991 & 0.868747 & 0.757425 & 0.610425 & 0.557175 & 0.498894 \\
20 & 1.07160 & 0.985383 & 0.872498 & 0.710573 & 0.648872 & 0.578675 \\
50 & 1.26124 & 1.18240 & 1.07332 & 0.911512 & 0.841283 & 0.759657 \\
100 & 1.37101 & 1.30734 & 1.21788 & 1.06582 & 0.995713 & 0.915161 \\
200 & 1.41898 & 1.36945 & 1.29441 & 1.16658 & 1.10986 & 1.03932 \\
300 & 1.40541 & 1.36426 & 1.30034 & 1.18955 & 1.13726 & 1.07102 \\
500 & 1.36569 & 1.32168 & 1.25578 & 1.16873 & 1.12608 & 1.07165 \\
700 & 1.30333 & 1.26649 & 1.21177 & 1.11961 & 1.08642 & 1.04002 \\
1000 & 1.20640 & 1.17737 & 1.13324 & 1.05670 & 1.02062 & 0.976927 \\
1500 & 1.06327 & 1.04244 & 1.01019 & 0.953121 & 0.926089 & 0.890630 \\
2000 & 0.946341 & 0.930792 & 0.906228 & 0.861898 & 0.840716 & 0.812401 \\
& & & & & & \\
\hline
\end{tabular}

Table D.3. $\mathrm{k}_{\infty}$ for $\mathrm{UO}_{2} \mathrm{~F}_{2}-\mathrm{H}_{2} \mathrm{O}$ systems using the LAW-238 ENDF/B-V library

\begin{tabular}{cllllll}
\hline $\mathrm{H} / \mathrm{X}$ & $5.0 \%$ & $4.0 \%$ & $3.0 \%$ & $2.0 \%$ & $1.7 \%$ & $1.4 \%$ \\
\hline 5 & 0.893399 & 0.805225 & 0.697273 & 0.562855 & 0.516176 & 0.466234 \\
10 & 0.972681 & 0.883838 & 0.770575 & 0.621987 & 0.568406 & 0.510019 \\
20 & 1.09211 & 1.00479 & 0.888273 & 0.724829 & 0.662461 & 0.592253 \\
50 & 1.28224 & 1.20381 & 1.09375 & 0.925627 & 0.856034 & 0.773132 \\
100 & 1.40136 & 1.33376 & 1.23639 & 1.08084 & 1.01347 & 0.930380 \\
200 & 1.45904 & 1.40357 & 1.32218 & 1.18791 & 1.12794 & 1.05223 \\
300 & 1.45275 & 1.40456 & 1.33326 & 1.21385 & 1.15975 & 1.09070 \\
500 & 1.39397 & 1.35510 & 1.29703 & 1.19816 & 1.15267 & 1.09394 \\
700 & 1.32187 & 1.28913 & 1.23998 & 1.15552 & 1.11627 & 1.06524 \\
1000 & 1.21714 & 1.19078 & 1.15099 & 1.08207 & 1.04974 & 1.00741 \\
1500 & 1.06806 & 1.04847 & 1.01881 & 0.966998 & 0.942495 & 0.910142 \\
2000 & 0.948921 & 0.933630 & 0.910468 & 0.869800 & 0.850457 & 0.824790 \\
& & & & & & \\
\hline
\end{tabular}


69

Table D.4. $\mathrm{k}_{\infty}$ for $\mathrm{UF}_{6}-\mathrm{HF}$ systems using the

LAW-238 ENDF/B-V library

\begin{tabular}{cllllll}
\hline $\mathrm{H} / \mathrm{X}$ & $5.0 \%$ & $4.0 \%$ & $3.0 \%$ & $2.0 \%$ & $1.7 \%$ & $1.4 \%$ \\
\hline 5 & 0.831253 & 0.743318 & 0.636440 & 0.504124 & 0.458321 & 0.409286 \\
10 & 0.914564 & 0.824171 & 0.709937 & 0.561783 & 0.508820 & 0.451284 \\
20 & 1.04227 & 0.951865 & 0.832172 & 0.666011 & 0.603294 & 0.533053 \\
50 & 1.24555 & 1.16386 & 1.04940 & 0.875412 & 0.803793 & 0718858 \\
100 & 1.37243 & 1.30237 & 1.20142 & 1.04023 & 0.970495 & 0.884678 \\
200 & 1.43456 & 1.37757 & 1.29385 & 1.15561 & 1.09380 & 1.01576 \\
300 & 1.42961 & 1.38034 & 1.30735 & 1.18501 & 1.12951 & 1.05866 \\
500 & 1.37158 & 1.33204 & 1.27295 & 1.17230 & 1.12596 & 1.06606 \\
700 & 1.29970 & 1.26653 & 1.21670 & 1.13104 & 1.09121 & 1.03937 \\
1000 & 1.19527 & 1.16862 & 1.12843 & 1.05879 & 1.02611 & 0.983292 \\
1500 & 1.04695 & 1.02719 & 0.997328 & 0.945162 & 0.920473 & 0.887886 \\
2000 & 0.928778 & 0.913395 & 0.890095 & 0.849232 & 0.829783 & 0.804005 \\
& & & & & & \\
\hline
\end{tabular}




\section{INTERNAL DISTRIBUTION}

1. T. A. Angelleli

2. E. J. Barber

3. S. M. Bowman

4. B. L. Broadhead

5. J. A. Bucholz

6. V. R. Cain

7. V. W. Campbell

8. R. Carter

9. R. L. Childs

10. E. C. Crume

11-14. D. M. D'Aquila

15. R. D. Dabbs

16. J. Declue

17. H. L. Dodds

18. L. C. Dolan

19-20. H. R. Dyer

21. W. E. Ford III

22. M. J. Haire

23. G. R. Handley

24. O. W. Hermann

25. T. W. Hines

26. D. F. Hollenbach

27. C. M. Hopper

28. J. C. Ingram

29. E. B. Johnson

30-39. W. C. Jordan

40. J. Kasten

41. K. Keith

42. M. R. Lambert

43. N. F. Landers
44-47. P. D. Lassiter

48. B. L. Lee

49. R. E. Lemming

50. T. Lemmons

51. L. C. Masters

52. R. L. Newvahner

53. L. Norris

54. R. L. Oxenham

55. C. V. Parks

56. L. M. Petrie

57. J.-P. Renier

58. R. C. Robinson

59-61. C. I Shappert

62. G. R. Smolen

63. R. V. Stachowiak

64. C. A. Sweet

65. J. S. Tang

66. R. G. Taylor

67. D. A. Tollefson

68-72. J. C. Turner, ORNL

73. J. C. Turner, ORGDP

74-75. R. G. Vornehm

76-79. C. C. Watson

80. R. M. Westfall

81. G. E. Whitesides

82. R. Q. Wright

83-84. Laboratory Records Dept.

85. Laboratory Records, ORNL-RC

86. Document Reference Section

87. Central Research Library

88. ORNL Patent Section 


\section{EXTERNAL DISTRIBUTION}

89. F. Alcorn, Babcock \& Wilcox, NNFD, P.O. Box 785, MS 46, Lynchburg, VA 24505

90. R. Anderson, Los Alamos National Laboratory, P.O. Box 1663, Los Alamos, NM 87544

91. J. W. Arendt, Chairman, IAEA Safety Standard No. 6, 109 Caldwell Dr., Oak Ridge, TN 37830

92. M. G. Bailey, Transportation Branch, ONMSS, U.S. Nuclear Regulatory Commission, MS 4E4, Washington, DC 20555

93. C. S. Barnett, Lawrence Livermore National Lab., Hazards Control Dept., Criticality Safety Group, P.O. Box 808, M/C L-390, Livermore, CA 94550

94. G. H. Bidinger, U.S. Nuclear Regulatory Commission, NMSS/FCSB, M/S 6H3, Washington, DC 20555

95. J. B. Briggs, EG\&G Idaho, Inc., Reactor \& Radiation Physics, P.O. Box 1625, Bldg. WCB, MS 3515, Idaho Falls, ID 83402

96. C. L. Brown, Consultant, 1050 Tantra Park Circle, Boulder, CO 80303

97. R. D. Busch, University of New Mexico, Chemical and Nuclear Engineering Dept., Building FEC, Room 205, Albuquerque, NM 87131

98. C. A. Caves, U.S. Department of Energy, MS NE-33, Washington, DC 20545

99. L. C. Davenport, Battelle Pacific Northwest Laboratories, Lab Safety Department, P.O. Box 999, M/S P7-78, Richland, WA 99352

100. J. K. Davis, Westinghouse Savannah River Co., Savannah River Site, Bldg. 730M, Aiken, SC 29808-0001

101. K. E. Elliott, U.S. Department of Energy, Albuquerque Operations Office, P.O. Box 5400 Kirtland AFB, Albuquerque, NM 87115

102. I. Fergus, U.S. Department of Energy, 19901 Germantown Road, NS-10, Germantown, MD 20874

103. W. L. Filippone, University of Arizona, Dept. of Nuclear \& Energy Engineering, Tucson, AZ 95721

104. L. E. Fischer, Lawrence Livermore National Lab., P.O. Box 808, Livermore, CA 94550

105. A. S. Garcia, Criticality Safety Representative, Argonne National Laboratory, Reactor Experiments \& Examination Div., ANL-W 765-A, P.O. Box 2528, Idaho Falls, ID 83403-2528

106. D. F. Giessing, U.S. Department of Energy, MS NE-42, Washington, DC 20545

107. W. L. Goodwin, Westinghouse Electric Corp., Regulatory Affairs Dept./Coml., Nuclear Fuel Div., Drawer R, Columbia, SC 29250

108. L. E. Hansen, Exxon Nuclear Co., Inc., 2101 Horn Rapids Rd., Richland, WA 99352

109. S. T. Huang, Manager, Nuclear Technology, The Ralph M. Parsons Co., 100 W. Walnut St., Pasadena, CA 91124

110. R. D. Ice, Eagle-Pitcher Industries, Inc., Research Laboratories, Miami, OK 743551

111. N. Ketzlach, The Ralph M. Parsons Co., Quality Assurance, 100 W. Walnut St., Pasadena, CA 91124 
112. R. J. Klotz, ABB Combustion Engineering Corp., Nuclear Engineering, P.O. Box 500, M/C 5318-2403, Windsor, CT 06095-0500

113. R. A. Knief, Ogden Environmental Energy Services, 6333 Stephens Crossing, P.O. Box 7010, Mechanicsburg, PA 17055-7010

114. B. L. Koponen, Lawrence Livermore National Lab., Nuclear Criticality Information System, P.O. Box 808, M/C L-542, Livermore, CA 94550

115. S. T. Lewis, Nuclear Fuel Services, Inc., Safety Department, 1205 Banner Hill Road, Erwin, TN 37650

116. W. R. Lloyd, Lawrence Livermore National Lab., Nuclear Systems Safety Program, P.O. Box 808, M/C L-197, Livermore, CA 94550

117. K. A. Lockie, U.S. Department of Energy, Idaho Operations Office, Nuclear Safety Branch, 785 DOE Place, MS 1116, Idaho Falls, ID 83401

118. S. Ludwig, U.S. Department of Energy, Chicago Operations Office, $9800 \mathrm{~S}$. Cass Ave., Argonne, IL 60439

119. H. F. Lutz, Lawrence Livermore National Lab., Nuclear Systems Safety Program, P.O. Box 808, M/C L-197, Livermore, CA 94550

120-121. C. E. MacDonald, U.S. Nuclear Regulatory Commission, NMSS/SGTB, MS 4E4, Washington, DC 20555

122. R. C. Marble, Westinghouse Environmental Management Company of Ohio, P.O. Box 398704, Cincinnati, OH 45239-8704

123. R. C. McBroom, U.S. Department of Energy, Oak Ridge Operations Office, Nuclear Safety Dept., P.O. Box 2001, MS G108, Oak Ridge, TN 37831-8733

124. D. A. McCaughey, General Electric Co., Nuclear Fuel Manufacturing Dept., P.O. Box 780, M/C J-26, Wilmington, NC 28402

125. T. McGlaughlin, Los Alamos National Laboratory, P.O. Box 1663, Los Alamos, NM 87544

126. J. N. McKamy, EG\&G Rocky Flats, Inc., P.O. Box 464, Bldg. 750, Golden, CO 80402-0464

127. R. E. Miles, Nuclear Criticality Specialist, Critical Mass Laboratory, P.O. Box 464, Golden, CO 80401

128. J. F. Mincey, Westinghouse Savannah River Co., Savannah River Site, Bldg. 730-M, Aiken, SC 29808-0001

129. S. P. Monahan, EG\&G Rocky Flats, Criticality Engineering, P.O. Box 464, Bldg. 886, Golden, CO 80401

130. Office of Assistant Manager, Energy Research and Development, U.S. Department of Energy, Oak Ridge Operations, P.O. Box 2002, Oak Ridge, TN 37831

131-132. Office of Scientific and Technical Information, U.S. Department of Energy, P.O. Box 62, Oak Ridge, TN 37831

133. G. T. Paulson, Westinghouse Idaho Nuclear Co., Inc., Nuclear and Industrial Safety, Criticality Safety Section, P.O. Box 4000, CPP 630, M/S 5222, Idaho Falls, ID 83403-5222

134. J. P. Petraglia, Sandia National Laboratories, P.O. Box 5800, Div. 6453, Albuquerque, NM 87185 
135. B. A. Pohl, Lawrence Livermore National Lab., Physics Dept., P.O. Box 808, M/C L-289, Livermore, CA 94550

136. F. G. Prohammer, Argonne National Laboratory, MCT Division, Argonne, IL 60439

137. N. L. Pruvost, Los Alamos National Laboratory, P.O. Box 1663, MS F691, Los Alamos, NM 87544

138. W. A. Pryor, PAI Corp., 116 Milan Way, Oak Ridge, TN 37830

139. F. Punch, Division of Quality Verification and Transportation, U.S. Department of Energy, MS EH-33.3, Washington, DC 20545

140. T. A. Reilly, Westinghouse Savannah River Co., Separations Technology, Bldg. 707F, Aiken, SC 29808-0001

141. J. N. Rogers, Sandia Laboratories, Div. 8324, Livermore, CA 94550

142. C. Sanders, Westinghouse Electric Corp., Regulatory Affairs Dept./Coml., Nuclear Fuel Div., Drawer R, Columbia, SC 29250

143. J. A. Schlesser, Los Alamos National Laboratory, P.O. Box 1663, Los Alamos, NM 87544

144. R. Shackelford, Nuclear Fuel Services, Inc., Safety Department, 205 Banner Hill Rd., Erwin, TN 37650

145. M. K. Sheaffer, Lawrence Livermore National Lab., P.O. Box 808, Livermore, CA 94550

145. N. C. Shepard, U.S. Department of Energy, Savannah River Operations Office, Safety Division, P.O. Box A, Aiken, SC 29802

147. R. W. Tayloe, Battelle Columbus Laboratories, Nuclear Systems Section, 505 King Ave., Rm. 11-5-129, Columbus, OH 43201-2693

148. J. T. Thomas, 16 Laurel Place, Norris, TN 37828-0296

149. S. E. Turner, HOLTEC International, 230 Normandy Circle E., Palm Harbor, FL 34683

150. H. W. Webb, Nuclear Fuel Services, Inc., Safety Department, 205 Banner Hill Road, Erwin, TN 37650-9718

151. F. G. Welfare, General Electric Co., Nuclear Fuel Manufacturing Dept., P.O. Box 780, Wilmington, NC 28402

152. L. L. Wetsel, Babcock \& Wilcox, NNFD, P.O. Box 785, MS 46, Lynchburg, VA 24505

153. B. H. White, U.S. Nuclear Regulatory Commission, NMSS/SGTB, Bldg. OWFN, Rm. 4F19, MS 4E4, Washington, DC 20555

154. R. E. Wilson, U.S. Nuclear Regulatory Commission, Fuel Cycle Safety, MS 6H3, Washington, DC 20555

155. C. J. Withee, U.S. Nuclear Regulatory Commission, ONMSS, MS 4E4, Washington, DC 20555 

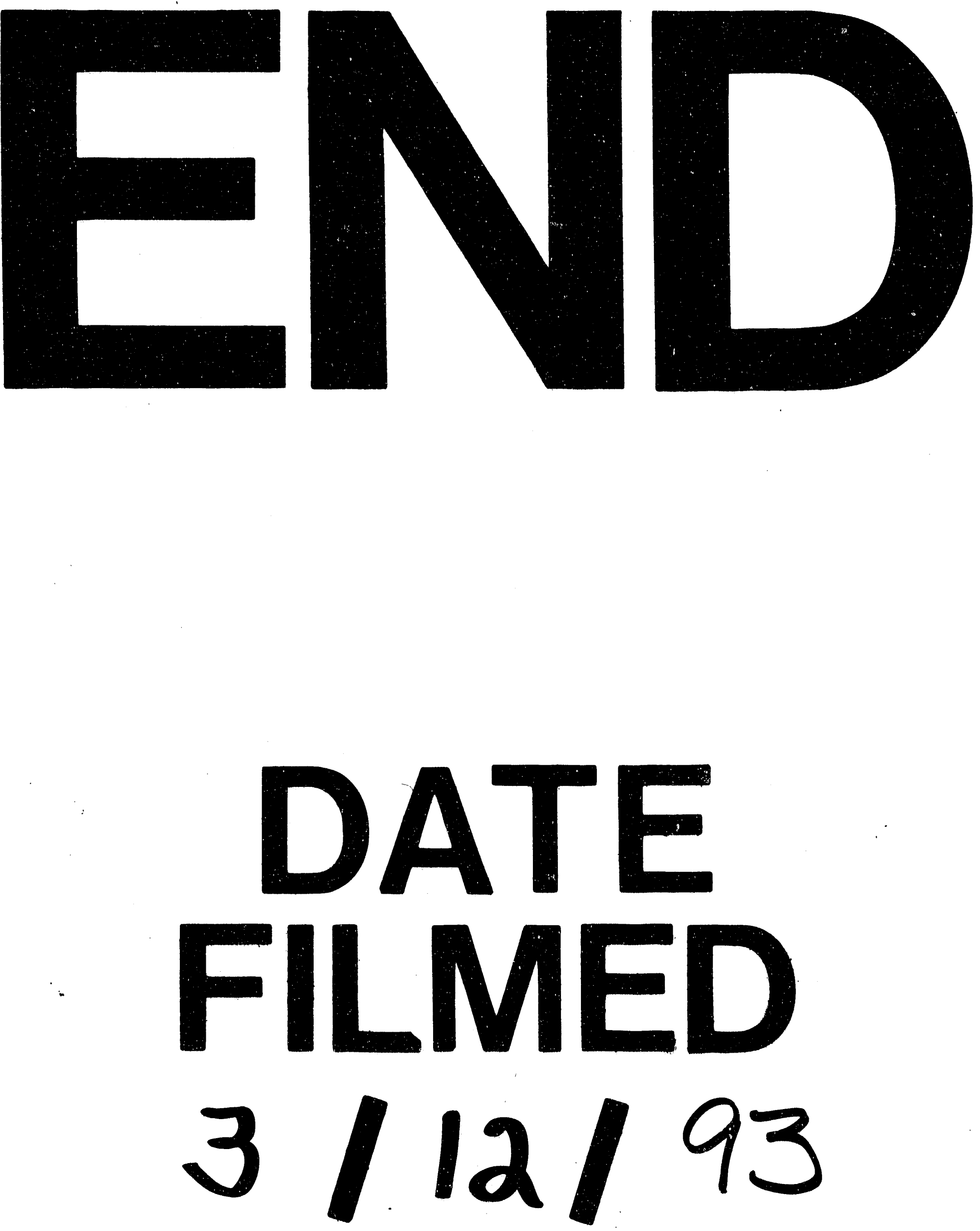

1 


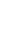

